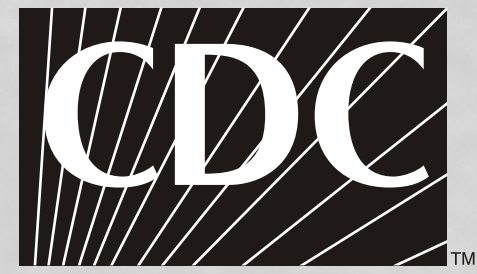

Workplace

Safety and Health

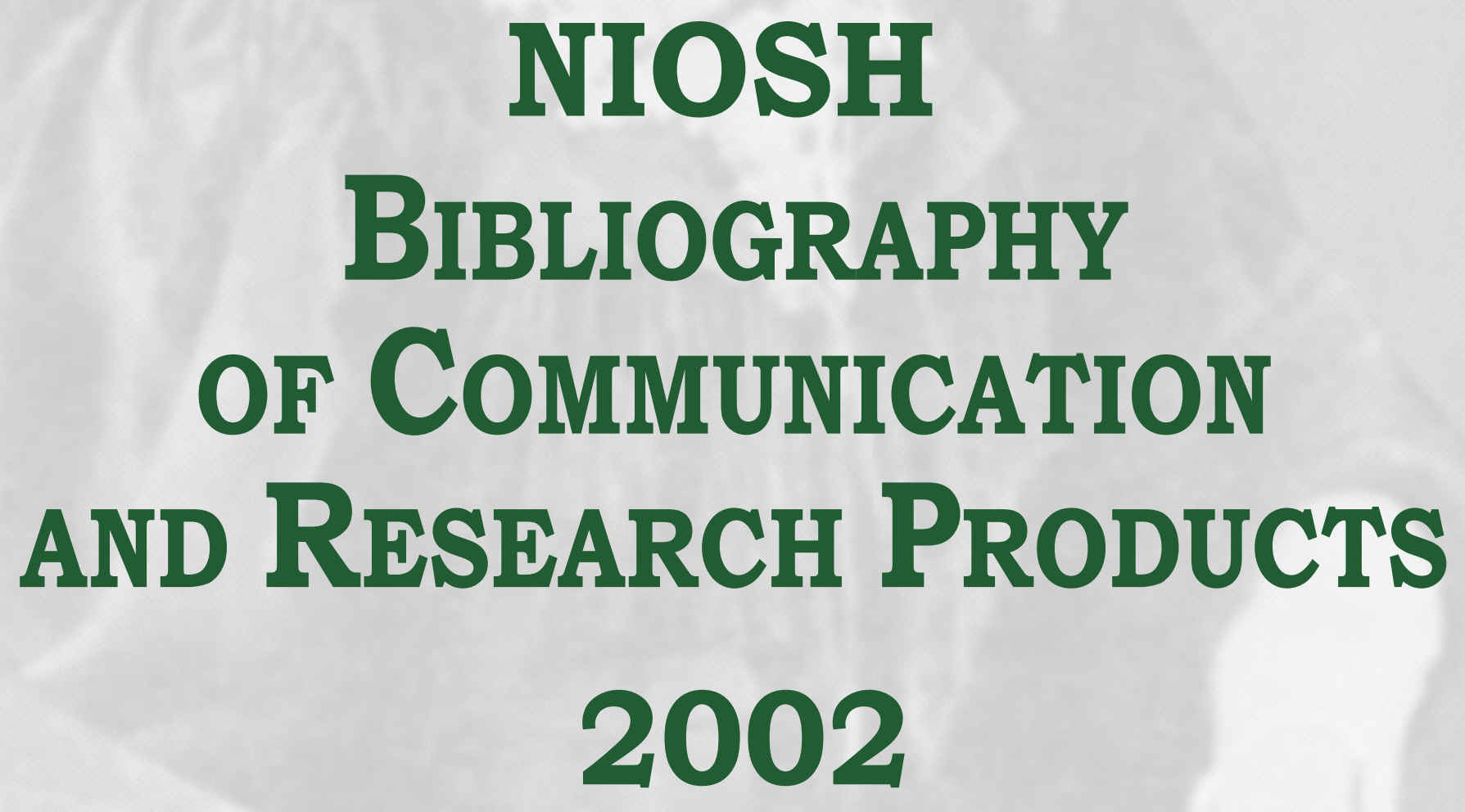

DEPARTMENT OF HEALTH AND HUMAN SERVICES

Centers for Disease Control and Prevention

National Institute for Occupational Safety and Health

N/osh 


\section{NIOSH BIBLIOGRAPHY OF COMMUNICATION AND RESEARCH PRODUCTS}

\section{2}

A Listing of NIOSH Publications for Calendar Year 2002

Department of Health and Human Services

Centers for Disease Control and Prevention

National Institute for Occupational Safety and Health Washington, DC

April 2003 


\section{FOREWORD}

Renewed recognition of NIOSH and the resources we can apply effectively in emergency situations sharply highlights the strength and quality of the scientific information we provide in all areas of workplace safety and health. The information contained in this bibliography demonstrates the consistent commitment of NIOSH and its partners to all workers as they face challenges to be safe and healthy while contributing to our nation's productivity. Please explore these products further and distribute them freely in workplaces and to our colleagues in the occupational health and safety community.

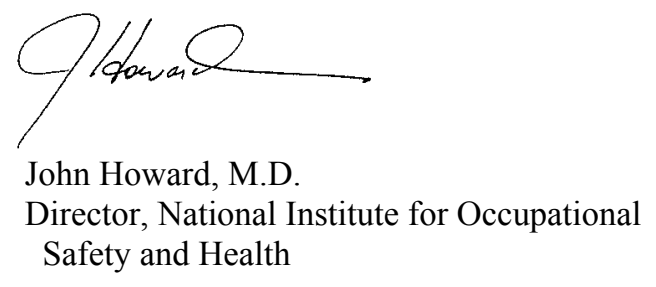




\section{PREFACE}

This publication is a compilation of research and communication products from all NIOSH Divisions and Laboratories for calendar year 2002. Extensive indexing has been added to this year's compilation so that each citation can be located by author, keyword, or when applicable, priority area of the National Occupational Research Agenda (NORA). Some citation numbers are missing or followed by the letter "a" or "b" because of corrections in the final editing process.

Comments and suggestions regarding future issues of this document may be forwarded to the Office of Health Communications, NIOSH Office of the Director, Hubert H. Humphrey Building, Washington, DC 20201. 


\section{CONTENTS}

I. Journal Articles $\ldots \ldots \ldots \ldots \ldots \ldots \ldots \ldots \ldots \ldots \ldots \ldots \ldots \ldots \ldots \ldots$. 1

II. Book Chapters/Proceedings/Abstracts/Technical Papers/Web . . . . . . . 33

III. Hazard Evaluation and Technical Assistance Reports $\ldots \ldots \ldots \ldots \ldots 65$

IV. NIOSH Numbered Publications $\ldots \ldots \ldots \ldots \ldots \ldots \ldots \ldots \ldots \ldots$

V. Fatality Assessment and Control Evaluation Reports $\ldots \ldots \ldots \ldots \ldots \ldots 77$

VI. Fire Fighter Fatality Investigation and Prevention Reports $\ldots \ldots \ldots \ldots .81$

VII. Technology News $\ldots \ldots \ldots \ldots \ldots \ldots \ldots \ldots \ldots \ldots \ldots \ldots \ldots \ldots \ldots \ldots$.

VIII. Keyword Index $\ldots \ldots \ldots \ldots \ldots \ldots \ldots \ldots \ldots \ldots \ldots \ldots \ldots \ldots \ldots \ldots, \ldots \ldots$

IX. National Occupational Research Agenda (NORA) Index $\ldots \ldots \ldots \ldots \ldots$

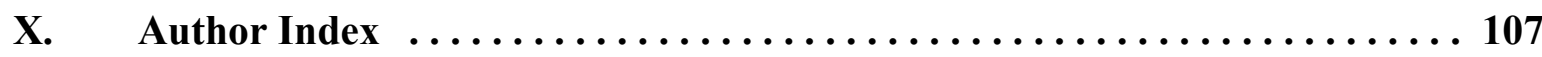




\section{JOURNAL ARTICLES}

*0002. Al-Humadi NH, Siegel PD, Lewis DM, Barger MW, Ma JYC, Weissman DN, Ma JKH [2002]. Alteration of intracellular cysteine and glutathione levels in alveolar macrophages and lymphocytes by diesel exhaust particle exposure. Environ Health Perspect 110(4):349-353. NORA: Work Environment and Workforce: Mixed Exposures

*0003. Al-Humadi NH, Siegel PD, Lewis DM, Barger MW, Ma JYC, Weissman DN, Ma JKH [2002]. The effect of diesel exhaust particles (DEP) and carbon black (CB) on thiol changes in pulmonary ovalbumin allergic sensitized brown Norway rats. Exp Lung Res 28(5):333-349. NORA: Work Environment and Workforce: Mixed Exposures

*0004. Antonini JM, Roberts JR, Jernigan MR, Yang HM, Ma JYC, Clarke RW [2002].

Residual oil fly ash increases the susceptibility to infection and severely damages the lungs after pulmonary challenge with a bacterial pathogen. Toxicol Sci 70:110-119.

NORA: Work Environment and Workforce: Mixed Exposures

*0005. Ashley KE, Song R, Schlecht PC [2002]. Performance criteria and characteristics of field screening test methods. Am Lab 34(12):32-39.

NORA: Research Tools and Approaches: Exposure Assessment Methods

*0006. Attfield M, Mannetje A, Steenland K, Checkoway H, Koskela R, Koponen M, Chen J, Hnizdo E, DeKlerk N, Dosemeci M [2002]. Development of quantitative exposure data for a pooled exposure-response analysis of 10 silica cohorts. Am J Ind Med 42:73-86.

NORA: Research Tools and Approaches: Surveillance Research Methods

*0007. Baron PA [2002]. Case studies: using a filter bypass leakage test for aerosol sampling cassettes. Appl Occup Environ Hyg 17(9):593-597.

NORA: Research Tools and Approaches: Exposure Assessment Methods

*0008. Baron PA, Bennett JS [2002]. Calculation of leakage and particle loss in filter cassettes. J Aerosol Sci Tech J 36(5):632-641.

NORA: Research Tools and Approaches: Exposure Assessment Methods

*0009. Baron PA, Deye GJ, Aizenberg VA, Castranova V [2002]. Generation of size-selected fibers for a nose-only inhalation toxicity study. Ann Occup Hyg 46(Suppl 1):186-190. 


\section{Journal Articles}

*0010. Baron PA, Khanina A, Martinez AB, Grinshpun SA [2002]. Investigation of filter bypass leakage and a test for aerosol sampling cassettes. Aerosol Sci Tech 36(8):857-865.

NORA: Research Tools and Approaches: Exposure Assessment Methods

*0011. Bartley DL, Ogden T, Song R [2002]. Frequency distributions from birth, death, and creation processes. Biosystems 66(3):179-191.

*0012. Beeckman-Wagner LAF, Wang ML, Petsonk EL, Wagner GR [2002]. Meretricious effects of coal dust [letter to the editor]. Am J Respir Crit Care Med 165(4):553.

NORA: Work Environment and Workforce: Special Populations at Risk

*0013. Bell JL [2002]. Changes in logging injury rates associated with use of feller-bunchers in West Virginia. J Saf Res 33:463-471.

NORA: Research Tools and Approaches: Intervention Effectiveness Research; Disease and Injury: Traumatic Injuries

*0014. Bello D, Streicher RP, Liu YC, Sparer J, Youngs F, Woskie SR [2002]. Field comparison of impingers and treated filters for sampling of total aliphatic isocyanates with the MAP reagent. Am Ind Hyg Assoc J 63(6):790-796.

NORA: Research Tools and Approaches: Exposure Assessment Methods

*0015. Bello D, Streicher RP, Woskie SR [2002]. Evaluation of the NIOSH draft method 5525 for determination of the total reactive isocyanate group (TRIG) for aliphatic isocyanates in autobody repair shops. J Environ Monit 4(3):351-360.

NORA: Research Tools and Approaches: Exposure Assessment Methods

*0016. Beus MJ, Ruest M [2002]. New technology for hoist conveyance monitoring and analysis. CIM Bulletin 95(1065):78-83.

*0017. Biagini RE, Murphy DM, Sammons DL, Smith JP, Striley CAF, MacKenzie BA [2002]. Development of multiplexed fluorescence microbead covalent assays (FMCAs) for pesticide biomonitoring. Bull Environ Contam Toxicol 68(4):470-477.

NORA: Research Tools and Approaches: Exposure Assessment Methods

*0018. Biddle EA, Hartley D [2002]. Fire and flame related events with multiple occupational injury fatalities in the United States, 1980-1995. Inj Contr Saf Promot 9(1):9-18.

*0019. Biddle EA, Marsh SM [2002]. Comparison of two fatal occupational injury surveillance systems in the United States. J Saf Res 33:337-354.

*0020. Birch ME [2002]. Analytical instrument performance criteria: occupational monitoring of particulate diesel exhaust by NIOSH method 5040. Appl Occup Environ Hyg 17(6):400-405.

NORA: Research Tools and Approaches: Exposure Assessment Methods 


\section{Journal Articles}

*0021. Boeniger M, Klingner T [2002]. In-use testing and interpretation of chemical resistant glove performance. Appl Occup Environ Hyg 17(5):368-378.

*0022. Burton N [2002]. Evaluation of a narcotic evidence holding room. Appl Occup Environ Hyg 17(5):315-321.

*0023. Cardarelli JJ, Spitz H, Rice CH, Buncher R, Elson H, Succop P [2002]. Significance of radiation exposure from work-related chest $\mathrm{x}$-rays for epidemiological studies of radiation workers. Am J Ind Med 42:490-501.

NORA: Research Tools and Approaches: Exposure Assessment Methods

*0024. Cardarelli JJ, Spitz HB, Rice C, Buncher CR, Elson H, Succop P, Daniels RD, Kubale T [2002]. Evaluation of work-related medical x-rays in epidemiological studies of nuclear workers. Radiat Res 158(6):807-808.

NORA: Research Tools and Approaches: Exposure Assessment Methods

*0025. Carel R, Boffetta P, Kauppinen T, Teschke K, Anderson A, Jappinen P, Pearce N, Rix Andreassen B, Bergeret A, Coggon D, Persson B, Szadkowska-Stanczyk I, Kielkowski D, Henneberger P, Kishi R, Facchini LA, et al. [2002]. Exposure to asbestos and lung pleural cancer mortality among pulp and paper industry workers. J Occup Environ Med 44(6):579-584.

NORA: Research Tools and Approaches: Exposure Assessment Methods; Disease and Injury: Asthma and Chronic Obstructive Pulmonary Disease

*0026. Carreón T, Santos-Burgoa C, Baron S, Hernandez S [2002]. Occupational health in Mexico. State-of-the-Art Review, Occup Med 17(3):437-453.

*0027. Castranova V, Frazer DG, Manley LK, Dey RD [2002]. Pulmonary alterations associated with inhalation of occupational and environmental irritants. Int Immunopharmacol 2(2-3):163-172. NORA: Work Environment and Workforce: Mixed Exposures

*0028. Castranova V, Porter D, Millecchia L, Ma JYC, Hubbs AF, Teass A [2002]. Effect of inhaled crystalline silica in a rat model: time course of pulmonary reactions. Mol Cell Biochem 234(1):177-184.

*0029. CDC (Centers for Disease Control and Prevention) [2002]. Evaluation of occupational exposures to air contaminants at the World Trade Center disaster site-New York, September-October 2001. MMWR 51(21):453-456.

*0030. CDC (Centers for Disease Control and Prevention) [2002]. Factors associated with pilot fatalities in work-related aircraft crashes-Alaska, 1990-1999. MMWR 51(16):347-349. 


\section{Journal Articles}

*0031. CDC (Centers for Disease Control and Prevention) [2002]. Fixed obstructive lung disease among former workers at a microwave popcorn factory-Missouri, 2000-2002. MMWR 51(16):345-347.

NORA: Disease and Injury: Asthma and Chronic Obstructive Pulmonary Disease

*0032. CDC (Centers for Disease Control and Prevention) [2002]. Occupational health guidelines for remediation workers at Bacillus anthracis-contaminated sites-United States, 2001-2002. MMWR 51(35):786-789.

*0033. CDC (Centers for Disease Control and Prevention) [2002]. Public health dispatch: update: cutaneous anthrax in a laboratory worker-Texas, 2002. MMWR 51(22):482.

*0034. CDC (Centers for Disease Control and Prevention) [2002]. Rashes among school children-14 states, 10/04/2001-02/27/2002. MMWR 51(08):161-164.

*0035. CDC (Centers for Disease Control and Prevention) [2002]. Respiratory illness among workers exposed to metalworking fluid contaminate with nontuberculous mycobacteria-Ohio, 2001. MMWR 51(16):349-352.

*0036. CDC (Centers for Disease Control and Prevention) [2002]. Surveillance summaries: adult blood lead epidemiology and surveillance-United States, 1998-2001. MMWR 51(11):1-10.

*0037. CDC (Centers for Disease Control and Prevention) [2002]. Suspected cutaneous anthrax in a laboratory worker-Texas, 2002. MMWR 51(13):279-281.

*0038. CDC (Centers for Disease Control and Prevention) [2002]. Use of respiratory protection among responders at the World Trade Center site—New York City, September 2001. MMWR 51(Special Issue):6-8.

*0039. CDC (Centers for Disease Control and Prevention) [2002]. Workers' Memorial Day-April 28, 2002. MMWR 51(16):345.

*0040. Chen F, Bower J, Leonard SS, Ding M, Lu Y, Rojanasakul Y, Kung H-F, Vallyathan V, Castranova V, Shi X [2002]. Protective roles of NF- $\kappa B$ for chromium (VI)-induced cytotoxicity is revealed by expression of IкB kinase- $\beta$ mutant. J Biol Chem 277(5):3342-3349.

NORA: Research Tools and Approaches: Cancer Research Methods

*0041. Chen F, Demers LM, Shi X [2002]. Upstream signal transduction of NF- $\kappa B$ activation: current drug targets. Inflamm Allergy 1:137-149.

NORA: Research Tools and Approaches: Cancer Research Methods 


\section{Journal Articles}

*0042. Chen F, Shi X [2002]. Intracellular signal transduction of cells in response to carcinogenic metals. Crit Rev Oncol Hematol 42(1):105-121.

NORA: Research Tools and Approaches: Cancer Research Methods

*0043. Chen F, Shi X [2002]. Signaling from toxic metals to NF- $\mathrm{BB}$ and beyond: not just a matter of reactive oxygen species. Environ Health Perspect 110(Suppl 5):807-811.

NORA: Research Tools and Approaches: Cancer Research Methods

*0044. Chun DTW, Chew V, Bartlett K, Gordon T, Jacobs RR, Larsson BM, Lewis DM, Liesivuori J, Michel O, Rylander R, Thorne PS, White EM, Gunn VC, Wurtz H [2002]. Second inter-laboratory study comparing endotoxin assay results from cotton dust. Ann Agric Environ Med 9(1):49-53.

*0045. Coffey CC, Lawrence RB, Zhuang Z, Campbell DL, Jensen PA, Myers WR [2002]. Comparison of five methods for fit-testing N95 filtering-facepiece respirators. Appl Occup Environ Hyg 17(10):723-730.

NORA: Research Tools and Approaches: Control Technology and Personal Protective Equipment

*0046. Cohen JI, Davenport DS, Stewart JA, Deitchman S, Hilliard JK, Chapman LE, B Virus Working Group. [2002]. Recommendations for prevention and therapy of persons exposed to B virus (Cercopithecine herpesvirus 1). Clin Infec Dis 35(10):1191-1203.

NORA: Disease and Injury: Infectious Diseases

*0047. Conti RS, Chasko LL [2002]. Thermal imaging cameras and their use in the mining industry. Transactions of SME 312:1-7.

NORA: Research Tools and Approaches: Control Technology and Personal Protective Equipment

*0048. Conway GA [2002]. Casting their lot upon the water: commercial fishing safety. Lancet 360:503-504.

*0049. Curwin B, Sanderson W, Reynolds S, Hein M, Alavanja M [2002]. Pesticide use and practices in an Iowa farm family pesticide exposure study. J Agric Saf Health 8(4):423-433.

NORA: Research Tools and Approaches: Exposure Assessment Methods

*0050. Cutlip RG, Hsiao H, Garcia R, Becker E, Mayeux B [2002]. Optimal hand locations for safe scaffold-end-frame disassembly. Appl Ergon 33(4):349-355.

*0051. Daftarian HS, Lushniak BD, Reh CM, Lewis DM [2002]. Evaluation of self-reported skin problems among workers exposed to toluene diisocyanate (TDI) at a foam manufacturing plant.

J Occup Environ Med 44(12):1197.

NORA: Disease and Injury: Allergic and Irritant Dermatitis 


\section{Journal Articles}

*0052. Davis KG, Marras WS, Heaney CA, Waters TR, Gupta P [2002]. The impact of mental processing and pacing on spine loading. Spine 27(23):2645-2653.

NORA: Disease and Injury: Musculoskeletal Disorders

*0053. Davis RR, Murphy WJ, Snawder JE, Striley CAF, Henderson D, Khan A, Krieg EF Jr. [2002]. Susceptibility to the ototoxic properties of toluene is species specific. Hear Res 166(1-2):24-32.

*0054. Davis RR, Sieber WK [2002]. Hearing protector use in noise-exposed workers: a retrospective look at 1983. Am Ind Hyg Assoc J 63(2):199-204.

NORA: Disease and Injury: Hearing Loss

*0056. Dillard SF, Hefflin B, Kaczmarek RG, Petsonk EL, Gross TP [2002]. Health effects associated with medical glove use. AORN J 76:88-96.

NORA: Disease and Injury: Asthma and Chronic Obstructive Pulmonary Disease

*0057. Dillon C, Petersen M, Tanaka S [2002]. Self-reported hand and wrist arthritis and occupation: data from the U.S. national health interview survey-occupational health supplement. Am J Ind Med 42:318-327.

NORA: Disease and Injury: Musculoskeletal Disorders

*0058. Ding M, Chen F, Shi X, Yucesoy B, Mossman B, Vallyathan V [2002]. Diseases caused by silica: mechanisms of injury and disease development. Int Immunopharmacol 2(2-3):173-182.

*0059. Ding M, Li J, Leonard SS, Shi X, Costa M, Castranova V, Vallyathan V, Huang C [2002]. Differential role of hydrogen peroxide in UV-induced signal transduction. Mol Cell Biochem 234-235(1-2):81-90.

*0060. Ding M, Shi X [2002]. Molecular mechanisms of Cr(VI)-induced carcinogenesis. Mol Cell Biochem 234-235(1-2):293-300.

NORA: Research Tools and Approaches: Cancer Research Methods

*0061. Dobroski H, Tuchman DP, Vinson RP, Timko RJ [2002]. Differential pressure response of 25-mm-diameter glass fiber filters challenged with coal and limestone dust mixtures. Appl Occup Environ Hyg 17(2):96-103.

*0062. Dong RG, Rakheja S, Smutz WP, Schopper A, Welcome D, Wu JZ [2002]. Effectiveness of a new method (TEAT) to assess vibration transmissibility of gloves. Int J Ind Ergon 30(1):33-48. NORA: Disease and Injury: Musculoskeletal Disorders; Research Tools and Approaches: Control Technology and Personal Protective Equipment 


\section{Journal Articles}

*0063. Drake P, Krieg E, Teass A, Vallyathan V [2002]. Two assays for urinary N-Acetyl- $\beta$-Dglucosaminidase compared. Clin Chem 48(9):1604-1605.

*0064. Driscoll T, Feyer AM, Stout N, Williamson A [2002]. Assessing the classification of work-relatedness of fatal incidents: a comparison between Australia, New Zealand, and the United States. Inj Control Saf Promot 9(1):32-39.

*0065. Durkin ME, Yuan BZ, Thorgeirsson SS, Popescu NC [2002]. Gene structure, tissue expression, and linkage mapping of the mouse DLC-1 gene (Arhgap7). Gene 288(1-2):119-127.

*0066. Dykeman R, Aguilar-Madrid G, Smith T, Juarez A, Piacitelli G, Hu H, Hernadez-Avila $\mathrm{M}$ [2002]. Lead exposure in Mexican radiator repair workers. Am J Ind Med 41:179-187.

*0067. Earnest GS [2002]. A control technology evaluation of state-of-the-art perchloroethylene dry-cleaning machines. Appl Occup Environ Hyg 17(5):352-359.

NORA: Research Tools and Approaches: Control Technology and Personal Protective Equipment; Intervention Effectiveness Research

*0068. Earnest GS, Dunn KH, Hall RM, McCleery RE, McCammon JB [2002]. An evaluation of an engineering control to prevent carbon monoxide poisonings of individuals on and around houseboats. Am Ind Hyg Assoc J 63(3):361-369.

NORA: Research Tools and Approaches: Control Technology and Personal Protective Equipment; Intervention Effectiveness Research

*0069. Earnest GS, Ewers LM, Ruder AM, Petersen MR, Kovein RJ [2002]. An evaluation of retrofit engineering control interventions to reduce perchloroethylene exposures in commercial dry-cleaning shops. Appl Occup Environ Hyg 17(2):104-111.

NORA: Research Tools and Approaches: Control Technology and Personal Protective Equipment; Intervention Effectiveness Research

*0070. Echt AS, Sieber WK [2002]. Case studies: control of silica exposure from hand tools in construction: grinding concrete. Appl Occup Environ Hyg 17(7):457-461.

NORA: Research Tools and Approaches: Control Technology and Personal Protective Equipment; Intervention Effectiveness Research

*0071. Echt AS, Sieber WK, Jones A, Jones E [2002]. Case studies: control of silica exposure in construction: scabbling concrete. Appl Occup Environ Hyg 17(12):809-813.

NORA: Research Tools and Approaches: Control Technology and Personal Protective

Equipment; Intervention Effectiveness Research

*0073. Estill CF, Baron SL, Steege A [2002]. Research and dissemination needs for ergonomics in agriculture. Public Health Rep 117:440-445.

NORA: Disease and Injury: Traumatic Injuries; Musculoskeletal Disorders 


\section{Journal Articles}

*0074. Estill CF, MacDonald LA [2002]. Ergonomic intervention: a case study in a mass production environment. Appl Occup Environ Hyg 17(8):521-527.

NORA: Disease and Injury: Musculoskeletal Disorders

*0075. Estill CF, Slavin TJ, Waters TR [2002]. Safety research: musculoskeletal disorders: a comparison of two national research agendas. Prof Saf 47(9):45-49.

NORA: Disease and Injury: Traumatic Injuries; Musculoskeletal Disorders

*0076. Estill CF, Watkins DS, Hall RM, O'Brien DM, Shulman SA [2002]. The impact of maintenance and design for ventilation systems. Appl Occup Environ Hyg 17:344-351. NORA: Research Tools and Approaches: Control Technology and Personal Protective Equipment

*0077. Estill CF, Watkins DS, Shulman SA, Kurimo RW, Kovein RJ [2002]. Engineering controls for furniture strippers to meet the OSHA methylene chloride PEL. Am Ind Hyg Assoc J 63(3):326-333.

NORA: Research Tools and Approaches: Control Technology and Personal Protective Equipment

*0078. Estill CF, Watkins DS, Shulman SA, Kurimo RW, Kovein RJ [2002]. Engineering controls for furniture strippers to meet the OSHA methylene chloride PEL [reply to letter to the editor]. Am Ind Hyg Assoc J 63(6):676-677.

NORA: Research Tools and Approaches: Control Technology and Personal Protective Equipment

*0079. Etherton JR, Cutlip RG, Harris JR, Ronaghi M, Snyder KA, Means KH, Mucino V, Howard S [2002]. Dynamic performance of the mechanism of an automatically deployable ROPS. J Agric Saf Health 8(1):113-118.

NORA: Research Tools and Approaches: Control Technology and Personal Protective Equipment; Disease and Injury: Traumatic Injuries

*0080. Etherton JR, Harris JR, Ronaghi M, Snyder KA, Cutlip RG, Means KH, Mucino V, Howard S [2002]. Static load test performance of the structure of an automatically deployable ROPS. J Agric Saf Health 8(1):119-126.

NORA: Research Tools and Approaches: Control Technology and Personal Protective Equipment; Disease and Injury: Traumatic Injuries

*0081. Ewers LM, Ruder AM, Petersen MR, Earnest GS, Goldenhar LM [2002]. Effects of retrofit emission controls and work practices on perchloroethylene exposures in small dry-cleaning shops. Appl Occup Environ Hyg 17(2):112-120.

NORA: Research Tools and Approaches: Control Technology and Personal Protective Equipment; Intervention Effectiveness Research

*0082. Feigley CE, Bennett JS, Khan J, Lee E [2002]. Performance of deterministic workplace exposure assessment models for various contaminant source, air inlet, and exhaust locations. Am Ind Hyg Assoc J 63(4):402-412.

NORA: Research Tools and Approaches: Control Technology and Personal Protective Equipment 


\section{Journal Articles}

*0083. Feigley CE, Bennett JS, Lee E, Khan J [2002]. Improving the use of mixing factors for dilution ventilation design. Appl Occup Environ Hyg 17(5):333-343.

NORA: Research Tools and Approaches: Control Technology and Personal Protective Equipment

*0084. Ferguson SA, Gaudes-MacLaren LL, Marras WS, Waters TR, Davis KG [2002]. Spinal loading when lifting from industrial storage bins. Ergonomics 45(6):399-414.

NORA: Disease and Injury: Musculoskeletal Disorders

*0085. Finkelman RB, Orem W, Castranova V, Tatu CA, Belkin HE, Zheng B, Lerch HE, Maharaj SV, Bates AL [2002]. Health impacts of coal and coal use: possible solutions. Int J Coal Geology 50:425-443.

*0086. Frasch HF [2002]. A random walk model of skin permeation. Risk Anal 22(2):265-276.

NORA: Research Tools and Approaches: Exposure Assessment Methods

*0087. Frasch HF, Landsittel DP [2002]. Regarding the sources of data analyzed with quantitative structure-skin permeability relationship methods. Eur J Pharm Sci 15(5):399-403. NORA: Research Tools and Approaches: Exposure Assessment Methods

*0088. Galinsky TL, Waters TR, Malit B [2002]. Overexertion injuries in home health care workers and the need for ergonomics. Home Health Care Services Quarterly 20(3):57-73. NORA: Disease and Injury: Musculoskeletal Disorders

*0089. Gallagher S, Marras WS, Davis KG, Kovacs K [2002]. Effects of posture on dynamic back loading during a cable lifting task. Ergonomics 45(5):380-398.

NORA: Disease and Injury: Low Back Disorders; Research Tools and Approaches: Intervention Effectiveness Research

*0090. Gao N, Ding M, Zheng JZ, Zhang Z, Leonard SS, Liu KJ, Shi X, Jiang BH [2002]. Vanadate-induced expression of hypoxia-inducible factor $1 \alpha$ and vascular endothelial growth factor through phosphatidylinositol 3-kinase/Akt pathway and reactive oxygen species. J Biol Chem 277(35):31963-31971.

NORA: Research Tools and Approaches: Cancer Research Methods

*0091. Gao N, Jiang BH, Leonard SS, Corum L, Zhang Z, Roberts JR, Antonini J, Zheng JZ, Flynn DC, Castranova V, Shi X [2002]. p38 signaling-mediated hypoxia-inducible factor $1 \alpha$ and vascular endothelial growth factor induction by $\mathrm{Cr}(\mathrm{VI})$ in DU145 human prostate carcinoma cells. J Biol Chem 277(47):45041-45048.

NORA: Research Tools and Approaches: Cancer Research Methods

*0093. Gao N, Keane MJ, Ong T, Ye J, Miller WE, Wallace WE [2002]. Effects of phospholipid surfactant on apoptosis induction by respirable quartz and kaolin in NR8383 rat pulmonary macrophages. Tox Appl Pharmac 175:217-225.

NORA: Research Tools and Approaches: Risk Assessment Methods 


\section{Journal Articles}

*0094. Gao P, Chen BT, Baron PA, Soderholm S [2002]. A numerical study of the performance of an aerosol sampler with a curved, blunt, multi-orificed inlet. Aerosol Sci Tech 36(5):540-553. NORA: Research Tools and Approaches: Exposure Assessment Methods

*0095. Gao P, Korley F, Martin J, Chen BT [2002]. Determination of unique microbial volatile organic compounds produced by five Aspergillus species commonly found in problem buildings. Am Ind Hyg Assoc J 63(2):135-140.

NORA: Research Tools and Approaches: Exposure Assessment Methods

*0096. Gao P, Martin J [2002]. Volatile metabolites produced by three strains of Stachybotrys chartarum cultivated on rice and gypsum board. Appl Occup and Environ Hyg 17(6):430-436. NORA: Research Tools and Approaches: Exposure Assessment Methods

*0097. Ghanem M, Battelli L, Kashon M, Vallyathan V, Ma JYC, Barger M, Nath J, Castranova $\mathrm{V}$, Hubbs AF [2002]. Coal dust is a modifier of pulmonary CYP1A1 induction in rats. The Toxicologist 66(1-S):19.

NORA: Work Environment and Workforce: Mixed Exposures

*0098. Glaser RA, Shulman S, Kurimo R, Piacitelli GM, Kent M [2002]. Data supporting a proposed American Society for Testing and Materials (ASTM) method for metalworking fluids Part 3: evaluation of a provisional ASTM method for metalworking fluids in a survey of metalworking facilities. J Test Eval 30(5):439-451.

*0099. Gomaa AE, Hu H, Bellinger D, Schwartz J, Tsaih SW, Gonzalez-Cossio T, Schnaas L, Aro A, Hernandez-Avila M [2002]. Maternal bone as independent risk factor for fetal neurotoxicity: a prospective study. Pediatrics 110(1):110-118.

NORA: Disease and Injury: Fertility and Pregnancy Abnormalities; Research Tools and Approaches: Exposure Assessment Methods

*0100. Gordon MN, Holcomb LA, Jantzen PT, DiCarlo G, Wilcock D, Boyett KW, Connor K, Melachrino J, O'Callaghan JP, Morgan D [2002]. Time course of the development of Alzheimerlike pathology in the doubly transgenic PS1+APP mouse. Exp Neurol 173(2):183-195.

*0101. Grajewski B, Cox C, Shrader SM, Murray WE, Edwards RM, Turner TW, Smith JM, Simon SD, Conover DL [2002]. The evidence that non-ionizing radiation alters men's hormone levels by W. James [reply to letter to the editor]. J Occup Environ Med 44(4):307.

NORA: Disease and Injury: Fertility and Pregnancy Abnormalities

*0102. Grajewski B, Waters MA, Whelan EA, Bloom TF [2002]. Radiation dose estimation for epidemiologic studies of flight attendants. Am J Ind Med 41:27-37.

NORA: Research Tools and Approaches: Exposure Assessment Methods 


\section{Journal Articles}

*0103. Grote AA, Kennedy ER [2002]. Workplace monitoring for volatile organic compounds using thermal desorption-gas chromatography-mass spectrometry. J Environ Monit 4(5):679-684. NORA: Research Tools and Approaches: Exposure Assessment Methods

*0104. Hales T, Boal WL, Ross CS [2002]. Hepatitis C virus infection among public safety workers [letter to the editor]. J Occup Environ Med 44(3):221-223.

*0105. Hall RM, Heitbrink WA, Reed LD [2002]. Evaluation of a tractor cab using real-time aerosol counting instrumentation. Appl Occup Environ Hyg 17(1):47-54.

NORA: Research Tools and Approaches: Exposure Assessment Methods

*0106. Hard DL, Myers J, Gerberich S [2002]. Traumatic injuries in agriculture. J Agric Saf Health 8(1):51-65.

*0107. Harney JM [2002]. IH in the Wake of Terror [letter to the editor]. The Synergist. January.

*0108. Hauser R, Eisen EA, Pothier L, Lewis D, Bledsoe T, Christiani DC [2002]. Spirometric abnormalities associated with chronic bronchitis, asthma, and airway hyperresponsiveness among boilermaker construction workers. Chest 121(6):2052-2060.

NORA: Work Environment and Workforce: Mixed Exposures

*0109. Henneberger P, Hoffman C, Magid D, Lyons E [2002]. Work-related worsening of asthma. Int J Occup Environ Health 8:291-296.

NORA: Disease and Injury: Asthma and Chronic Obstructive Pulmonary Disease

*0110. Higgins D, Tierney J, Hanrahan L [2002]. Preventing youth worker fatalities: the Fatality Assessment and Control Evaluation (FACE) Program. AAOHN J 50(11):508-514.

*0112. Hnizdo E, Sullivan P, Bang KM, Wagner GR [2002]. Association between chronic obstructive pulmonary disease and employment by industry and occupation in the US population: a study of data from the third national health and nutrition examination survey. Am J Epidemiol 156(6):738-746.

NORA: Disease and Injury: Asthma and Chronic Obstructive Pulmonary Disease

*0113. Hnizdo V, Wallace WE [2002]. Monte Carlo analysis of the detection of clay occlusion of respirable quartz particles using multiple voltage scanning electron microscopy. Scanning 24(5):264-269.

NORA: Work Environment and Workforce: Mixed Exposures; Research Tools and Approaches: Exposure Assessment Methods

*0114. Hodous TK, Washenitz F, Newton B [2002]. Occupational burns from oxygen resuscitator fires: the hazard of aluminum regulators. Am J Ind Med 42(1):63-69. 


\section{Journal Articles}

*0115. Hsiao H, Guan J, Weatherly M [2002]. Accuracy and precision of two in-shoe pressure measurement systems. Ergonomics 45(8):537-555.

*0116. Hsiao H, Long D, Snyder KA [2002]. Anthropometric differences among occupational groups. Ergonomics 45(2):136-152.

NORA: Research Tools and Approaches: Control Technology and Personal Protective Equipment

*0118. Huang C, Li J, Ke Q, Leonard SS, Jiang B-H, Zhong X-S, Costa M, Castranova V, Shi X [2002]. Ultraviolet-induced phosphorylation of p70(S6K) at $\operatorname{Thr}(389)$ and $\operatorname{Thr}(421) / \operatorname{Ser}(424)$ involves hydrogen peroxide and mammalian target of rapamycin but not Akt and atypical protein kinase C1. Cancer Res 62(20):5689-5697.

NORA: Research Tools and Approaches: Cancer Research Methods

*0119. Huang GD, Feuerstein M, Sauter SL [2002]. Occupational stress and work-related upper extremity disorders: concepts and models. Am J Ind Med 41(5):298-314.

NORA: Disease and Injury: Traumatic Injuries

*0120. Hubbs AF, Battelli LA, Goldsmith WT, Porter DW, Frazer D, Friend S, Schwegler-Berry D, Mercer RR, Reynolds JS, Grote A, Castranova V, Kullman G, Fedan JS, Dowdy J, Jones WG [2002]. Necrosis of nasal and airway epithelium in rats inhaling vapors of artificial butter flavoring. Toxicol Appl Pharmacol 185(2):128-135.

NORA: Work Environment and Workforce: Mixed Exposures

*0121. Huffman LJ, Prugh DJ, Brumbaugh K, Ding M [2002]. Influence of hyperthyroidism on rat lung cytokine production and nuclear factor- $\kappa \mathrm{B}$ activation following ozone exposure. Inhal Toxicol 14(11):1161-1174.

NORA: Disease and Injury: Fertility and Pregnancy Abnormalities; Work Environment and Workforce: Special Populations at Risk

*0122. Huy J [2002]. Needlestick injuries (in Japanese). Japanese Language Journal: Infection Control International Perspectives 4:1-14.

*0123. Jacob L, Alvarenga K, Morata TC [2002]. The effects of occupational exposure to lead on the auditory system: an analysis of the literature. Rev Bras Otorrinolaringol 68(4):564-569. NORA: Disease and Injury: Hearing Loss

*0124. Jensen PA, Talbot EA, Moffat HJ, Wells CD [2002]. Occupational risk from germicidal irradiation radiation lamps. Int J Tuberc Lung Dis 6(6):738-741.

NORA: Research Tools and Approaches: Control Technology and Personal Protective Equipment 


\section{Journal Articles}

*0126. Johnson EA, O'Callaghan JP, Miller DB [2002]. Chronic treatment with supraphysiological levels of corticosterone enhances d-MDMA-induced dopaminergic neurotoxicity in the C57BL/6J female mouse. Brain Res 933(2):130-138.

*0127. Johnson EA, Shvedova AA, Kisin E, O'Callaghan JP, Kommineni C, Miller DB [2002]. d-MDMA during vitamin E deficiency: effects on dopaminergic neurotoxicity and hepatotoxicity. Brain Res 933(2):150-163.

*0128. Joseph P, Lei YX, Whong WZ, Ong TM [2002]. Molecular cloning and functional analysis of a novel cadmium-responsive proto-oncogene. Cancer Res 62(3):703-707.

NORA: Research Tools and Approaches: Cancer Research Methods

*0129. Joseph P, Lei YX, Whong WZ, Ong TM [2002]. Oncogenic potential of mouse translation elongation factor-1 $\delta$, a novel cadmium-responsive proto-oncogene. $\mathrm{J}$ Biol Chem 277(8):6131-6136.

NORA: Research Tools and Approaches: Cancer Research Methods

*0130. Kagan VE, Kisin ER, Kawai K, Serinkan BF, Osipov AN, Serbinova EA, Wolinsky I, Shvedova AA [2002]. Toward mechanism-based antioxidant interventions. Ann NY Acad Sci 959:188-198.

NORA: Disease and Injury: Allergic and Irritant Dermatitis

*0133. Keane MJ, Hornsby-Myers JL, Stephens JW, Harrison JC, Myers JR, Wallace WE [2002]. Characterization of hard metal dusts from sintering and detonation coating processes and comparative hydroxyl radical production. Chem Res Toxicol 15(8):1010-1016.

NORA: Work Environment and Workforce: Mixed Exposures; Research Tools and Approaches: Exposure Assessment Methods

*0134. Keshava C, Frye BL, Wolff MS, McCanlies EC, Weston A [2002]. Waf-1 (p21) and p53 polymorphisms in breast cancer. Cancer Epidemiol Biomarkers Prev 11(1):127-130.

NORA: Research Tools and Approaches: Cancer Research Methods

*0135. Kiefer M, Delaney L [2002]. Counting coin and paper currency. Appl Occup Environ Hyg 17(6):389-397.

*0136. Kissell FN [2002]. Control of dust in hard-rock tunnels. Tunnel Business, Aug: pp. 28-33.

*0137. Kissell FN, Sacks HK [2002]. Inaccuracy of area sampling for measuring the dust exposure of mining machine operators in coal mines. Min Eng 54(2):33-39.

NORA: Research Tools and Approaches: Exposure Assessment Methods 


\section{Journal Articles}

*0138. Kittusamy NK [2002] Ergonomic risk factors: a study of heavy earthmoving machinery operators. Prof Saf, October: pp. 38-45.

*0139. Klingner T, Boeniger M [2002]. A critique of assumptions about selecting chemicalresistant gloves: a case for workplace evaluation of glove efficacy. Appl Occup Environ Hyg 17(5):360-367.

*0140. Kocamis H, Gahr SA, Battelli L, Hubbs AF, Killefer J [2002]. IGF-1, IGF-11, and IGFreceptor-1 transcript and IGF-11 protein expression in myostatin knockout mice tissues. Muscle Nerve 26(1):55-63.

*0141. Kohler JL, Sottile J, Trutt FC [2002]. Condition monitoring of stator windings in induction motors: part I experimental investigation of the effective negative-sequence impedance detector. IEEE Transactions Ind Appl 38(5):1447-1453.

*0142. Kowalski KM, Podlesny A [2002]. A study of burnout in accident investigators in the U.S. mining industry. Int J Emerg Mgt 1(2):155-169.

*0143. Kozel PJ, Davis RR, Krieg EF Jr., Shull GE, Erway LC [2002]. Deficiency in plasma membrane calcium atpase isoform 2 increases susceptibility to noise-induced hearing loss in mice. Hear Res 164(1-2):231-239.

*0144. Kreiss K, Gomaa A, Kullman G, Fedan K, Schleiff P, Simoes E, Enright P [2002]. Endemic bronchiolitis obliterans syndrome in microwave popcorn workers: a new occupational lung hazard. Am J Respir Crit Care Med 165:A461.

NORA: Disease and Injury: Asthma and Chronic Obstructive Pulmonary Disease

*0145. Kreiss K, Gomaa A, Kullman G, Fedan K, Simoes E, Enright P [2002] Clinical bronchiolitis obliterans in workers at a microwave-popcorn plant. N Engl J Med 347(5):330-338.

NORA: Disease and Injury: Asthma and Chronic Obstructive Pulmonary Disease

*0147. Kuempel ED, Smith RJ, Dankovic DA, Bailer AJ, Stayner LT [2002]. Concordance of rat and human-based risk estimates for particle-related lung cancer. Ann Occup Hyg 46(Suppl

1):62-66.

NORA: Research Tools and Approaches: Risk Assessment Methods

*0148. Kuempel ED, Tran CL [2002]. Comparison of human lung dosimetry models: implications for risk assessment. Ann Occup Hyg 46(Suppl 1):337-341.

NORA: Research Tools and Approaches: Risk Assessment Methods

*0149. Landsittel D, Singh H, Arena VC, Anderson SJ [2002]. Measuring a binary response's range of influence in logistic regression [letter to the editor]. Am Statistician 56(4):337-338. 


\section{Journal Articles}

*0150. Lawryk N [2002]. NIOSH methods for field portable analysis of airborne metals. The Synergist 1(10):30-31.

NORA: Research Tools and Approaches: Exposure Assessment Methods

*0151. Lawson C, LeMasters G, Levin L, Liu J [2002]. Pregnancy hormone metabolite patterns, pregnancy symptoms, and coffee consumption. Am J Epidemiol 156(5):428-437.

NORA: Disease and Injury: Fertility and Pregnancy Abnormalities

*0152. Lawson CC, Schnorr TM, Daston GP, Grajewski B, Marcus M, McDiarmid M, Murono E, Perreault SD, Shelby M, Schrader SM [2002]. An occupational reproductive research agenda for the third millennium. Environ Health Perspect doi:10.1289/ehp.5548 [http://dx.doi.org/]. NORA: Disease and Injury: Fertility and Pregnancy Abnormalities

*0153. Lee E, Burnett CA, Lalich N, Cameron LL, Sestito JP [2002]. Proportionate mortality of crop and livestock farmers in the United States, 1984-1993. Am J Ind Med 42:410-420.

*0154. Lee WJ, Teschke K, Kauppinen T, Andersen A, Jappinen P, Szadkowska-Stanczyk I, Pearce N, Persson B, Bergeret A, Facchini LA, Kishi R, Kielkowski D, Rix BA, Henneberger P, Sunyer J, Colin D, et al. [2002]. Mortality from lung cancer in workers exposed to sulfur dioxide in the pulp and paper industry. Environ Health Perspect 110(10):991-995.

NORA: Disease and Injury: Asthma and Chronic Obstructive Pulmonary Disease

*0155. Lei YX, Joseph P, Ong TM [2002]. Antisense inhibition of translation initiation factor 3 reverses its oncogenic potential. Teratog Carcinog Mutagen 22(6):403-409.

NORA: Research Tools and Approaches: Cancer Research Methods

*0156. Leigh JP, Romano PS, Schenker MB, Kreiss K [2002]. Occupational and environmental health costs of occupational COPD and asthma. Chest 121:264-272.

NORA: Disease and Injury: Asthma and Chronic Obstructive Pulmonary Disease

*0157. Lentz TJ [2002]. Building consensus the work of powerful partnerships. Am Ind Hyg Assoc J 13(11):25-26.

*0158. Leonard SS, Cutler D, Ding M, Vallyathan V, Castranova V, Shi X [2002]. Antioxidant properties of fruit and vegetable juices: more to the story than ascorbic acid. Ann Clin Lab Sci 32(2):193-200.

NORA: Research Tools and Approaches: Cancer Research Methods

*0159. Leonard SS, Mowrey K, Pack D, Shi X, Castranova V, Kuppusamy P, Vallyathan V [2002]. In vivo bioassays of acute asbestosis and its correlation with ESR spectroscopy and imaging in redox status. Mol Cell Biochem 234(1):369-377.

NORA: Research Tools and Approaches: Cancer Research Methods 


\section{Journal Articles}

*0160. Leonard SS, Vallyathan V, Castranova V, Shi X [2002]. Generation of reactive oxygen species in the enzymatic reduction of $\mathrm{PbCrO}_{4}$ and related DNA damage. Mol Cell Biochem 234(1):309-315.

NORA: Research Tools and Approaches: Cancer Research Methods

*0161. Li H, Wang ML, Seixas N, Ducatman A, Petsonk EL [2002]. Respiratory protection: associated factors and effectiveness of respirator use among underground coal miners. Am J Ind Med 42:55-62.

NORA: Research Tools and Approaches: Control Technology and Personal Protective Equipment

*0162. Li J, Huang B, Shi X, Castranova V, Vallyathan V, Huang C [2002]. Involvement of hydrogen peroxide in asbestos-induced NAFT activation. Molecul Cell Biochem 234/235(1-2): 161-168.

NORA: Research Tools and Approaches: Cancer Research Methods

*0163. Linch KD [2002]. Respirable concrete dust-silicosis hazard in the construction industry. Appl Occup Environ Hyg 17(3):209-221.

NORA: Work Environment and Workforce: Special Populations at Risk

*0164. Litton CD [2002]. Studies of the measurement of respirable coal dusts and diesel particulate matter. Meas Sci Technol 13(3):365-374.

NORA: Research Tools and Approaches: Exposure Assessment Methods

*0165. Litton CD [2002]. The use of light scattering and ion chamber responses for the detection of fires in diesel-contaminated atmospheres. Fire Saf J 37:409-425.

*0166. Lu B, Wang L, Medan D, Toledo D, Huang C, Chen F, Shi X, Rojanasakul Y [2002]. Regulation of Fas (CD95)-induced apoptosis by nuclear factor- $\kappa \mathrm{B}$ and tumor necrosis factor- $\alpha$ in macrophages. Am J Physiol Cell Physiol 283(3):C831-C838.

NORA: Research Tools and Approaches: Cancer Research Methods

*0167. Ma JYC, Ma JKH [2002]. The dual effect of the particulate and organic components of diesel exhaust particles on the alteration of pulmonary immune/inflammatory responses and metabolic enzymes. J Environ Sci Health C 20(2):117-147.

NORA: Work Environment and Workforce: Mixed Exposures

*0168. Ma JYC, Yang HM, Barger MW, Siegel PD, Zhong BZ, Kriech AJ, Castranova V [2002]. Alteration of pulmonary cytochrome p-450 system: effects of asphalt fume condensate exposure. J Toxicol Environ Health A 65(17):1247-1260.

NORA: Work Environment and Workforce: Mixed Exposures

*0169. Ma Q [2002]. Induction and superinduction of 2,3,7,8-tetrachlorodibenzo-p-dioxininducible poly(ADP-ribose) polymerase: role of the aryl hydrocarbon receptor/aryl hydrocarbon 


\section{Journal Articles}

receptor nuclear translocator transcription activation domains and a labile transcription repressor. Arch Biochem Biophys 404(2):309-316.

*0170. Ma Q, Baldwin KT [2002]. A cycloheximide-sensitive factor regulates TCDDp-induced degradation of the aryl hydrocarbon receptor. Chemosphere 46(9-10):1491-1500.

*0171. Ma Q, Kinneer K [2002]. Chemoprotection by phenolic antioxidants: Inhibition of tumor necrosis factor alpha induction in macrophages. J Biol Chem 277(4):2477-2484.

*0172. Mainelis G, Gorny RL, Reponen T, Trunov M, Grinshpun SA, Baron PA, Yadav J, Willeke K [2002]. Effect of electrical charges and fields on injury and viability of airborne bacteria. Biotechnol Bioeng 79(2):229-241.

*0173. Mainelis G, Willeke K, Baron PA, Grinshpun SA, Reponen T [2002]. Induction charging and electrostatic classification of micrometer-size particles for investigating the electrobiological properties of airborne microorganisms. Aerosol Sci Tech 36(4):479-491.

*0174. Mannetje A, Steenland K, Attfield M, Boffetta P, Checkoway H, DeKlerk N, Koskela RS [2002]. Exposure-response analysis and risk assessment for silica and silicosis mortality in a polled analysis of six cohorts. Occup Environ Med 59:723-728.

NORA: Disease and Injury: Asthma and Chronic Obstructive Pulmonary Disease

*0175. Mannetje A, Steenland K, Checkoway H, Koskela R, Koponen M, Attfield M, Chen J, Hnizdo E, DeKlerk N, Dosemeci M [2002]. Development of quantitative exposure data for a pooled exposure-response analysis of 10 silica cohorts. Am J Ind Med 42:73-86.

NORA: Research Tools and Approaches: Exposure Assessment Methods

*0176. Matheson JM, Lemus R, Lange RW, Karol MH, Luster MI [2002]. Role of tumor necrosis factor in toluene diisocyanate asthma. Am J Respir Cell Mol Biol 27(4):396-405.

*0177. Maynard AD [2002]. Experimental determination of ultrafine TiO2 dis-agglomeration in surrogate pulmonary surfactant: preliminary results. Ann Occup Hyg 46(Suppl 1):197-202.

NORA: Research Tools and Approaches: Exposure Assessment Methods

*0178. Maynard AD [2002]. Thoracic size-selection of fibres: dependence of penetration on fibre length for five thoracic sampler types. Ann Occup Hyg 46(6):511-522.

NORA: Research Tools and Approaches: Exposure Assessment Methods

*0179. Maynard AD, Maynard RL [2002]. A derived association between ambient aerosol surface area and excess mortality using historic time series data. Atmos Environ 36(36-37):5561-5567.

NORA: Research Tools and Approaches: Exposure Assessment Methods 


\section{Journal Articles}

*0180. Maynard AD, Maynard RL [2002]. Ambient aerosol exposure-response as a function of particulate surface area: reinterpretation of historical data using numerical modeling. Ann Occup Hyg 46(Suppl 1):444-449.

NORA: Research Tools and Approaches: Exposure Assessment Methods

*0181. Maynard AD, Zimmer AT [2002]. Evaluation of grinding aerosols in terms of alveolar dose: the significance of using mass, surface area, and number metrics. Ann Occup Hyg 46 (Suppl 1):315-319.

NORA: Research Tools and Approaches: Exposure Assessment Methods

*0182. McCanlies E, Landsittel DP, Yucesoy B, Vallyathan V, Luster ML, Sharp DS [2002]. Significance of genetic information in risk assessment and individual classification using silicosis as a case model. Ann Occup Hyg 46(4):375-381.

*0183. McDevitt JJ, Breysse PN, Bowman JD, Sassone DM [2002]. Comparison of extremely low frequency (ELF) magnetic field personal exposure monitors. J Expo Anal Environ Epidemiol 12(1):1-8.

NORA: Research Tools and Approaches: Exposure Assessment Methods

*0184. McKernan JL, Piacitelli GM, Roegner KC, Delaney L, Boiano JM [2002]. Occupational exposures in seismic retrofitting operations. Appl Occup Environ Hyg 17(2):75-81.

NORA: Research Tools and Approaches: Exposure Assessment Methods

*0185. Mead KR, Gressel MG [2002]. Case studies: protecting building environments from airborne chemical, biological, or radiological attacks. Appl Occup Environ Hyg 17(10):649-658. NORA: Research Tools and Approaches: Control Technology and Personal Protective Equipment

*0186. Mendell MJ, Fisk WJ, Kreiss K, Levin H, Arch B, Alexander D, Cain WS, Girman JR, Hines CJ, Jensen PA, Milton DK, Rexroat LP, Wallingford KM [2002]. Improving the health of workers in indoor environments: priority research needs for a national occupational research agenda. Am J Publ Health 92:1430-1440.

NORA: Work Environment and Workforce: Indoor Environment

*0187. Mendell MJ, Fisk WJ, Petersen MR, Hines CJ, Dong M, Faulkner D, Deddens JA, Ruder AM, Sullivan D, Boeniger MF [2002]. Indoor particles and symptoms among office workers: results from double-blind cross-over study. Epidemiol 13(3):296-304.

NORA: Work Environment and Workforce: Indoor Environment

*0188. Miller AK, Tepper A, Sieber WK [2002]. Historical risks of tuberculin skin test conversion among non-physician staff at a large urban hospital. Am J Ind Med 42:228-235.

*0189. Miller DB, O'Callaghan JP [2002]. Neuroendocrine aspects of the response to stress. Metabolism 51(6):5-10. 


\section{Journal Articles}

*0190. Miller W [2002]. Revisiting the geometry of a ternary diagram with the half-taxi metric. Math Geology 34(3):275-290.

NORA: Research Tools and Approaches: Risk Assessment Methods

*0191. Modriansky M, Tyurina YY, Tyurin VA, Matsura T, Shvedova AA, Yalowich JC, Kagan VE [2002]. Anti-/pro-oxidant effects of phenolic compounds in cells: are colchicine metabolites chain-breaking antioxidants? Toxicology 177(1):105-117.

NORA: Disease and Injury: Allergic and Irritant Dermatitis

*0192. Morata TC [2002]. Toxicological highlight: interaction between noise and asphyxiants: a concern for toxicology and occupational health. Toxicol Sci 66(1):1-3.

NORA: Disease and Injury: Hearing Loss

*0193. Morata TC, Campo P [2002]. Ototoxic effects of styrene alone or in concert with other agents: a review. Noise and Health 4(14):15-24.

NORA: Disease and Injury: Hearing Loss

*0194. Morata TC, Johnson AC, Nylen PR, Svensson EB, Cheng J, Krieg EF Jr., Lindblad AC, Ernstgard L, Franks JR [2002]. Audiometric findings in workers exposed to low levels of styrene and noise. J Occup Environ Med 44(9):806-814.

NORA: Disease and Injury: Hearing Loss

*0195. Morata TC, Little MB [2002]. Protocol: suggested guidelines for studying the combined effects of occupational exposure to noise and chemicals on hearing. Noise and Health 4(14):73-87. NORA: Disease and Injury: Hearing Loss

*0196. Murono EP, Derk RC [2002]. Exposure to octylphenol increases basal testosterone formation by cultured adult rat Leydig cells. J Steroid Biochem Mol Biol 81(2):181-189.

NORA: Disease and Injury: Fertility and Pregnancy Abnormalities

*0197. Murphy WJ, Franks JR, Krieg EF Jr. [2002]. Hearing protector attenuation: models of attenuation distributions. J Acoust Soc Am 111(5, Pt 1):2109-2116.

NORA: Disease and Injury: Hearing Loss

*0198. Neton J, Wenzl T, Cardarelli J, Utterback D [2002]. Retrospective exposure assessment for radiological technologists. Radiat Res 158:804-805.

NORA: Research Tools and Approaches: Exposure Assessment Methods

*0199. Ortega H, Kreiss K, Schill D, Weissman D [2002]. Fatal asthma from powdering shark cartilage and review of fatal occupational asthma literature. Am J Ind Med 42:50-54.

NORA: Disease and Injury: Asthma and Chronic Obstructive Pulmonary Disease 


\section{Journal Articles}

*0200. Ortega H, Weissman D, Carte D, Banks D [2002]. Use of specific inhalation challenge in the evaluation of workers at risk for occupational asthma: a survey of pulmonary, allergy and occupational medicine residency training programs in the United States and Canada. Chest 121(4):1323-1328.

NORA: Disease and Injury: Asthma and Chronic Obstructive Pulmonary Disease

*0201. Ottlinger M, Zumwalde R, Roscoe R, Kosnett M, Hipkins K, Meister R, Materna B [2002]. Adult blood lead testing: a pivotal role for labs in interpretation and surveillance. Clin Lab News 28(6):12-14.

*0202. Page EH, Cook CK, Hater MA, Mueller CA, Grote AA, Mortimer VD [2002]. Visual and ocular changes associated with exposure to two tertiary amines. Occup Environ Med 60:69-75.

*0203. Page SJ, Organiscak JA [2002]. Using proximate analysis to characterize airborne dust generation from bituminous coals. Aerosol Sci Tech 36(6):721-733.

NORA: Research Tools and Approaches: Control Technology and Personal Protective Equipment

*0204. Palermo T, Ehlers J [2002]. Coalitions: partnerships to promote agricultural health and safety. J Agric Saf Health 8(2):161-174.

NORA: Work Environment and Workforce: Special Populations at Risk

*0205. Park R, Rice F, Stayner L, Smith R, Gilbert S, Checkoway H [2002]. Exposure to crystalline silica, silicosis, and lung disease other than cancer in diatomaceous earth industry workers: a quantitative risk assessment. Occup Environ Med 59(1):36-43.

NORA: Research Tools and Approaches: Risk Assessment Methods; Disease and Injury: Asthma and Chronic Obstructive Pulmonary Disease

*0206. Park RM [2002]. Hazard identification in occupational injury: reflections on standard epidemiologic methods. Int J Occup Environ Health 8:354-362.

*0207. Park RM, Bailer AJ, Stayner LT, Halperin W, Gilbert SJ [2002]. An alternate characterization of hazard in occupational epidemiology: years of life lost per years worked. Am J Ind Med 42:1-10.

NORA: Research Tools and Approaches: Risk Assessment Methods

*0208. Parks CG, Cooper GS, Nylander-French LA, Sanderson WT, Dement JM, Cohen PL, Dooley MA, Treadwell EL, St. Clair EW, Gilkeson GS, Hoppin JA, Savitz DA [2002]. Occupational exposure to crystalline silica and risk of systemic lupus erythematosus: a population-based, case-control study in the southeastern United States. Arthritis Rheum 46(7):1840-1850. 


\section{Journal Articles}

*0209. Petrovitch H, Ross W, Abbott R, Sanderson W, Sharp D, Tanner C, Masaki K, Blanchette P, Popper J, Foley D, Launer L, White L [2002]. Plantation work and risk of Parkinson disease in a population-based longitudinal study. Arch Neurol 59(11):1787-1792. NORA: Work Environment and Workforce: Special Populations at Risk

*0210. Petsonk EL [2002]. Work-related asthma and implications for the general public. Environ Health Perspect 110(Suppl 4):569-572.

NORA: Disease and Injury: Asthma and Chronic Obstructive Pulmonary Disease

*0211. Petsonk EL, Dillard SF, Hefflin B, Kaczmarek RG, Gross TP [2002]. Health effects associated with medical glove use. AORN J 76:88-96.

NORA: Research Tools and Approaches: Exposure Assessment Methods

*0212. Porter DW, Barger M, Robinson VA, Leonard SS, Landsittel D, Castranova V [2002]. Comparison of low doses of aged and freshly fractured silica on pulmonary inflammation and damage in the rat. The Toxicologist 66(1S):353.

*0213. Porter DW, Barger M, Robinson VA, Leonard SS, Landsittel D, Castranova V [2002]. Comparison of low doses of aged and freshly fractured silica on pulmonary inflammation and damage in the rat. Toxicology 175(1-3):63-71.

*0214. Porter DW, Hubbs AF, Robinson VA, Battelli LA, Greskevitch M, Barger M, Landsittel D, Jones W, Castranova V [2002]. Comparative pulmonary toxicity of blasting sand and five substitute abrasive blasting agents. J Toxicol Environ Health 65:1121-1140.

NORA: Research Tools and Approaches: Intervention Effectiveness Research

*0215. Porter DW, Millecchia L, Robinson VA, Hubbs A, Willard P, Pack D, Ramsey D, McLaurin J, Khan A, Landsittel D, Teass A, Castranova V [2002]. Enhanced nitric oxide and reactive oxygen species production and damage after inhalation of silica. Am J Physiol Lung Cell Mol Physiol 283(2):L485-L493.

*0216. Porter DW, Ye J, Ma J, Barger M, Robinson VA, Ramsey D, McLaurin J, Khan A, Landsittel D, Teass A, Castranova V [2002]. Time course of pulmonary response of rats to inhalation of crystalline silica: NF- $\mathrm{BB}$ activation, inflammation, cytokine production, and damage. Inhal Toxicol 14(4):349-367.

*0217. Powers JR, Harris JR, Etherton JR, Snyder KA, Ronaghi M, Newbraugh BH [2002]. Performance of an automatically deploying ROPS on ASAE test. J Agric Saf Health 7:51-61. NORA: Research Tools and Approaches: Control Technology and Personal Protective Equipment; Disease and Injury: Traumatic Injuries 


\section{Journal Articles}

*0218. Prasher D, Morata TC, Campo P, Fechter L, Johnson AC, Lund SP, Pawlas K, Starck J, Sliwinska-Kowalska M, Sulkowski W [2002]. Noise Chem: an European Commission research project on the effects of exposure to noise and industrial chemicals on hearing and balance. Noise and Health 4(14):41-48.

NORA: Disease and Injury: Hearing Loss

*0219. Prasher D, Morata TC, Campo P, Fechter L, Johnson AC, Lund SP, Pawlas K, Starck J, Sulkowski W, Sliwinska-Kowalska M [2002]. Noise Chem: an European Commission research project on the effects of exposure to noise and industrial chemicals on hearing and balance. Int $\mathbf{J}$ Occup Med Environ Health 15(1):5-11.

NORA: Disease and Injury: Hearing Loss

*0220. Prince MM [2002]. Distribution of risk factors for hearing loss: implications evaluating risk of occupational noise-induced hearing loss. J Acoust Soc Am 112(2):557-567.

NORA: Disease and Injury: Hearing Loss

*0221. Qian Y, Baisden JM, Cherezova L, Summy JM, Guappone-Koay A, Shi X, Mast T, Pustula J, Zot HG, Mazloum N, Lee MY, Flynn DC [2002]. PKC phosphorylation increases the ability of AFAP-110 to cross-link actin filaments. Mol Biol Cell 13(7):2311-2322.

NORA: Research Tools and Approaches: Cancer Research Methods

*0222. Rakheja S, Dong R, Welcome D, Schopper AW [2002]. Estimation of tool-specific isolation performance of antivibration gloves. Int J Ind Ergon 30(2):71-87.

NORA: Disease and Injury-Musculoskeletal Disorders; Research Tools and Approaches: Control Technology and Personal Protective Equipment

*0223. Rakheja S, Wu JZ, Dong RG, Schopper AW, Boileau PE [2002]. A comparison of biodynamic models of the human hand-arm system for applications to hand-held power tools. $\mathrm{J}$ Sound Vibration 249(1):55-82.

NORA: Disease and Injury: Musculoskeletal Disorders; Research Tools and Approaches: Control Technology and Personal Protective Equipment

*0224. Rao KMK, Meighan T, Bowman L [2002]. Role of mitogen-activated protein kinase activation in the production of inflammatory mediators: differences between primary rat alveolar macrophages and macrophage cell lines. J Toxicol Environ Health A 65(10):757-768.

*0225. Reutman SR, LeMasters GK, Kesner JS, Shukla R, Krieg EF Jr., Knecht EA, Lockey JE [2002]. Urinary reproductive hormone level differences between African American and Caucasian women of reproductive age. Fertil Steril 78(2):383-391.

NORA: Disease and Injury: Fertility and Pregnancy Abnormalities 


\section{Journal Articles}

*0226. Reutman SR, LeMasters GK, Knecht EA, Shukla R, Lockey JE, Burroughs GE, Kesner JS [2002]. Evidence of reproductive endocrine effects in women with occupational fuel and solvent exposures. Environ Health Perspect 110(8):805-811.

NORA: Disease and Injury: Fertility and Pregnancy Abnormalities

*0227. Reynolds B, deWit H, Richards JB [2002]. Delay of gratification and delay discounting in rats. Behav Processes 59(3):157-168.

*0228. Reynolds JS, Stemple KJ, Petsko RA, Ebeling TR, Frazer DG [2002]. Nonlinear model for offline correction of pulmonary waveform generators. IEEE Trans Biomed Eng 49 (12 Pt 2):1567-1573.

*0229. Reynolds SJ, Thorne PS, Donham KJ, Croteau EA, Kelly KM, Lewis D, Whitmer M, Heederik DJJ, Douwes J, Connaughton I, Koch S, Malmberg P, Larsson BM, Milton DK [2002]. Comparison of endotoxin assays using agricultural dusts. Am Ind Hyg Assoc J 63(4):430-438.

*0230. Rinsky RA, Hornung RW, Silver SR, Tseng CY [2002]. Benzene exposure and hematopoietic mortality: a long-term epidemiologic risk assessment. Am J Ind Med 42:474-480.

*0231. Robinson JW, Swanson N [2002]. Psychological well-being of working women: a crosscultural perspective. Curr Women's Health Rep June 2(3):214-218.

NORA: Work Environment and Workforce: Special Populations at Risk

*0232. Roegner KC, Sieber WK, Echt AS [2002]. Case studies: evaluation of diesel exhaust controls. Appl Occup Environ Hyg 17(1):1-7.

NORA: Research Tools and Approaches: Control Technology and Personal Protective Equipment; Intervention Effectiveness Research

*0233. Rozovsky I, Hoving S, Anderson CP, O'Callaghan J, Finch CE [2002]. Equine estrogens induce apolipoprotein $\mathrm{E}$ and glial fibrillary acidic protein in mixed glial cultures. Neurosci Lett 323(3):191-194.

*0234. Ruff TM, Holden TP [2002]. Mine eyes: proximity alert for monster trucks. GPS World Jul:16-22.

*0235. Sampson AR, Singh H [2002]. Min and max scorings for two sample partially ordered categorical data. J Stat Plan Infer 107:219-236.

*0236. Sanderson WT, Hein MJ, Taylor L, Curwin BD, Kinnes GM, Seitz TA, Popovic T, Holmes HT, Kellum ME, McAllister SK, Whaley DN, Tupin EA, Walker T, Freed JA, Small DS, Klusaritz B, Bridges JH [2002]. Surface sampling methods for Bacillus anthracis spore contamination. Emerg Infect Dis 8(10):1145-1151.

NORA: Research Tools and Approaches: Exposure Assessment Methods 


\section{Journal Articles}

*0237. Sargent LM, Senft JR, Lowry DT, Jefferson AM, Tyson FL, Malkinson AM, Coleman AE, Reynolds SH [2002]. Specific chromosomal aberrations in mouse lung adenocarcinoma cell lines detected by spectral karyotyping: a comparison with human lung adenocarcinoma. Cancer Res 62(4):1152-1157.

*0238. Saxena RK, Weissman D, Saxena QB, Simpson J, Lewis DM [2002]. Kinetics of changes in lymphocyte sub-populations in mouse lungs after intrapulmonary infection with $M$. bovis (Bacillus Calmette-Guerin) and identity of cells responsible for INF $\gamma$ responses. Clin Exp Immunol 128(3):405-410.

NORA: Disease and Injury: Infectious Diseases

*0239. Saxena RK, Weissman D, Simpson J, Lewis DM [2002]. Murine model of BCG lung infection: dynamics of lymphocyte subpopulations in lung interstitium and tracheal lymph nodes. J Biosci 27(2):143-153.

NORA: Disease and Injury: Infectious Diseases

*0240. Schiffbauer WH [2002]. Active proximity warning system for surface and underground mining applications. Min Eng 54(12):40-48.

NORA: Disease and Injury: Traumatic Injuries; Research Tools and Approaches: Intervention Effectiveness Research

*0241. Schrader SM, Breitenstein MJ, Clark JC, Lowe BD, Turner TW [2002]. Nocturnal penile tumescence and rigidity testing in bicycling patrol officers. J Androl 23(6):927-934.

NORA: Disease and Injury: Fertility and Pregnancy Abnormalities

*0242. Schubauer-Berigan M [2002]. Medical radiation exposures in occupational studies: discussion. Radiat Res 158(6):808.

*0243. Schuler CR, Deubner DC, McCawley M, Berakis MT, Henneberger PK, Kreiss K [2002]. Job-related risk of beryllium disease at a beryllium copper alloy facility. Am Rev Respir Crit Care Med 165:A28.

NORA: Research Tools and Approaches: Exposure Assessment Methods

*0244. Schulte PA [2002]. Approaches to sharing occupational safety and health information on a global scale. Am J Ind Med 41(3):210-216.

*0245. Schwerha DJ, Orr CS, Chen BT, Soderholm SC [2002]. Direct-on-filter analysis of crystalline silica using photoacoustic Fourier transform-infrared spectroscopy. Analytica Chimica Acta 457(2):257-264.

NORA: Research Tools and Approaches: Exposure Assessment Methods 


\section{Journal Articles}

*0246. Scott AE, Kashon ML, Yucesoy B, Luster MI, Tinkle S [2002]. Insights into the quantitative relationship between sensitization and challenge for allergic contact dermatitis reactions. Toxicol Appl Pharmacol 183(1):66-70.

NORA: Disease and Injury: Allergic and Irritant Dermatitis

*0247. Shulman SA, Smith JP [2002]. A method for estimation of bias and variability of continuous gas monitor data: application to carbon monoxide monitor accuracy. Am Ind Hyg Assoc J 63(5):559-566.

NORA: Research Tools and Approaches: Exposure Assessment Methods

*0248. Shvedova AA, Kisin E, Murray A, Goldsmith T, Reynolds JS, Castranova V, Frazer DG, Kommineni C [2002]. Metal working fluids: sub-chronic effects on pulmonary functions in B6C3F1 mice given vitamin E deficient and sufficient diets. Toxicology 177(2-3):285-297.

NORA: Disease and Injury: Allergic and Irritant Dermatitis

*0249. Shvedova AA, Kisin E, Murray A, Smith C, Castranova V, Kommineni C [2002]. Enhanced oxidative stress in the skin of vitamin $\mathrm{E}$ deficient mice exposed to semisynthetic metal working fluids. Toxicology 176(1-2):135-143.

NORA: Disease and Injury: Allergic and Irritant Dermatitis

*0250. Shvedova AA, Kisin ER, Murray AR, Kommineni C, Castranova V, Mason RP, Kadiiska MB, Gunther MR [2002]. Antioxidant balance and free radical generation in vitamin E-deficient mice after dermal exposure to cumene hydroperoxide. Chem Res Toxicol 15(11):1451-1459.

NORA: Disease and Injury: Allergic and Irritant Dermatitis

*0251. Shvedova AA, Tyurina YY, Kawai K, Tyurin VA, Kommineni C, Castranova V, Fabisiak JP, Kagan BE [2002]. Selective peroxidation and externalization of phosphatidylserine in normal human epidermal keratinocytes during oxidative stress induced by cumene hydroperoxide. J Invest Dermatol 118(6):1008-1018.

NORA: Disease and Injury: Allergic and Irritant Dermatitis

*0252. Sieber WK, Petersen MR, Stayner LT, Malkin R, Mendell MJ, Wallingford KM, Wilcox TG, Crandall MS, Reed L [2002]. HVAC characteristics and occupant health. ASHRAE J 44(9):49-53. NORA: Work Environment and Workforce: Indoor Environment

*0253. Silver SR, Rinsky RA, Cooper SP, Hornung RW, Lai D [2002]. Effect of follow-up time on risk estimates: a longitudinal examination of the relative risks of leukemia and multiple myeloma in a rubber hydrochloride cohort. Am J Ind Med 42:481-489.

*0254. Simeonova PP, Luster MI [2002]. Arsenic carcinogenicity: relevance of c-Src activation. Mol Cell Biochem 234-235(1-2):277-282. 


\section{Journal Articles}

*0255. Simeonova PP, Wang S, Hulderman T, Luster MI [2002]. c-Src-dependent activation of the epidermal growth factor receptor and mitogen-activated protein kinase pathway by arsenic. J Biol Chem 277(4):2945-2950.

*0256. Sinclair RC, Maxfield AM, Marks EL, Thompson DR, Gershon RRM [2002]. Prevalence of safer needle devices and factors associated with their adoption: results of a national hospital survey. Public Health Rep 117(40):340-349.

NORA: Research Tools and Approaches: Intervention Effectiveness Research

*0257. Singh H, Hnizdo V, Demchuk E [2002]. Probabilistic model for two dependent circular variables. Biometrika 89(3):719-723.

*0258. Sinkule E, Turner N, Eschenbacher W [2002]. Metabolic and respiratory responses during the performance of a one-hour Man Test 4. J Int Society for Respiratory Protection 19(I - II):49-57.

NORA: Research Tools and Approaches: Control Technology and Personal Protective Equipment

*0259. Small D, Klusaritz V, Muller P [2002]. Evaluation of Bacillus anthracis contamination inside the Brentwood mail processing and distribution center-District of Columbia. JAMA 287(4):445-446.

NORA: Research Tools and Approaches: Exposure Assessment Methods

*0260. Smith JP, Bird AJ [2002]. Relationship of sampling efficiency for manikin-mounted personal samplers to efficiency measurements made independent of manikin. J Aerosol Sci 33(9):1235-1259. NORA: Research Tools and Approaches: Exposure Assessment Methods

*0261. Smutz WP, Dong RG, Han B, Schopper AW, Welcome DE, Kashon ML [2002]. A method for reducing adaptor misalignment when testing gloves using USO 10819. Ann Occup Hyg 46(3):309-315.

NORA: Disease and Injury: Musculoskeletal Disorders; Research Tools and Approaches: Control Technology and Personal Protective Equipment

*0262. Sottile J, Trutt FC, Kohler JL [2002]. Condition monitoring of stator windings in induction motors: part I - experimental investigation of voltage mismatch detectors. IEEE Trans Ind Appl 38(5):1454-1459.

*0263. Spruill MD, Song B, Whong W-Z, Ong T [2002]. Proto-oncogene activation and genomic instability of cadmium-induced cell transformation in BALB/c-3T3 cells. J Toxicol Environ Health A 65(24):2131-2144.

NORA: Research Tools and Approaches: Cancer Research Methods

*0264. Sriram K, Benkovic SA, Miller DB, O'Callaghan JP [2002]. Obesity exacerbates chemically induced neurodegeneration. Neuroscience 115(4):1335-1346. 


\section{Journal Articles}

*0265. Sriram K, Matheson JM, Benkovic SA, Miller DB, Luster MI, O'Callaghan JP [2002]. Mice deficient in TNF receptors are protected against dopaminergic neurotoxicity: implications for Parkinson's disease. FASEB J 16(11):1474-1476.

*0266. Stayner L, Toraason M, Hattis D [2002]. Risk assessment at the crossroads of the 21st century: Opportunities and challenges for research. Human Ecol Risk Assess 8(6):1195-1202. NORA: Research Tools and Approaches: Risk Assessment Methods

*0268. Steenland K [2002]. Response to letter from S.K. Seilkop [letter to the editor]. Cancer Causes Control 13:785.

*0269. Steenland K [2002]. Ten-year update on mortality among mild-steel welders. Scand J Work Environ Health 28(3):163-167.

*0270. Steenland K, Attfield M, Mannetje A [2002]. Pooled analysis of kidney disease mortality and silica exposure in three cohorts. Ann Occup Hyg 46(Suppl):4-9.

*0271. Steenland K, Deddens J [2002]. Response to letter from Dr. Ulm [letter to the editor]. Cancer Causes Control 13:781-782.

*0272. Steenland K, Henley J, Thun M [2002]. All cause and cause-specific mortality by educational status in two million people in two ACS cohorts. Am J Epidemiol 156:11-21.

*0273. Stout NA, Linn HI [2002]. Occupational injury prevention research: progress and priorities. Inj Prev 8(4)(Suppl):iv9-iv14.

*0274. Streicher RP, Reh CM, Key-Schwartz R, Schlecht PC, Cassinelli ME, O'Connor PF [2002]. Analytical instrument performance criteria: selecting isocyanate sampling and analytical methods. Appl Occup Environ Hyg 17(3):157-162.

NORA: Research Tools and Approaches: Exposure Assessment Methods

*0275. Sussell A, Ashley KE [2002]. Field measurement of lead in workplace air and paint chip samples by ultrasonic extraction and portable anodic stripping voltammetry. J Environ Monit 4(1):156-161.

NORA: Research Tools and Approaches: Exposure Assessment Methods

*0276. Talbot EA, Jensen PA, Moffat HJ, Wells CD [2002]. Occupational risk from ultraviolet germicidal irradiation (UVGI) lamps. Int J Tuberc Lung Dis 6(6):738-741.

NORA: Research Tools and Approaches: Control Technology and Personal Protective Equipment 


\section{Journal Articles}

*0277. Taylor L, Jones RL, Ashley KE [2002]. Analytical instrument performance criteria: on-site measurement of blood-lead concentrations using field-portable electroanalysis. Appl Occup Environ Hyg 17(12):818-821.

NORA: Research Tools and Approaches: Exposure Assessment Methods

*0278. Taylor MD, Roberts JR, Hubbs AF, Reasor MJ, Antonini JM [2002]. Quantitative image analysis of drug-induced lung fibrosis using laser scanning confocal microscopy. Toxicol Sci 67(2):295-302.

*0279. Teixeira CF, Giraldo daSilva Augusto L, Morata TC [2002]. Occupational exposure to insecticides and their effects on the auditory system. Noise and Health 4(14):31-39.

NORA: Disease and Injury: Hearing Loss

*0280. Temple JG, Miller DB, Barthalmus GT [2002]. Differential vulnerability of snake species to MPTP: a behavioral and biochemical comparison in ratsnakes (Elaphe) and watersnakes (Nerodia). Neurotoxicol Teratol 24(2):227-233.

*0281. Teshale EH, Painter J, Burr GA, Mead P, Wright SV, Cseh LF, Zabrocki R, Collins R, Kelley KA, Hadler JL, Swerdlow DL, Connecticut Anthrax Response Team [2002]. Environmental sampling for spores of Bacillus anthracis. Emerg Infect Dis [serial online]. Available from: URL: http://www.cdc.gov/ncidod/EID/vol8no10/02-0398.htm

*0282. Toraason MA, Andersen M, Bogdanffy M, Dankovic D, Faustman E, Foster P, Frederick C, Haber L, Kimmel CA, Lewis S, McClellan R, Melnick R, Mirer F, Morgan K, Schaeffer V, Silbergeld E [2002]. Improving risk assessment: toxicological research needs. Hum Ecol Risk Assess $8(6): 1405-1419$.

NORA: Research Tools and Approaches: Risk Assessment Methods

*0283. Tran CL, Kuempel ED, Castranova V [2002]. A rat lung model of exposure, dose, and response to inhaled silica. Ann Occup Hyg 46(Suppl 1):14-17.

NORA: Research Tools and Approaches: Risk Assessment Methods

*0284. Trout D, Nimgade A, Mueller CA, Hall RM, Earnest GS [2002]. Health effects and occupational exposures among office workers near the World Trade Center disaster site. J Occup Environ Med 44(7):601-605.

*0285. Tyurina YY, Tyurin VA, Shvedova AA, Fabisiak JP, Kagan VE [2002]. Peroxidation of phosphatidylserine in mechanisms of apoptotic signaling. Methods Enzymol 352:159-174.

*0286. Utt WK, Miller GG, Howie WL, Woodward CC [2002]. New drill-monitoring system evaluates strata strength in real time. Transactions of SME 312:87-92. 


\section{Journal Articles}

*0287. Vainio H, Stayner L [2002]. Can health promotion at the workplace help in preventing cancer? Scand J Work Environ Health 28(3):137-139.

NORA: Research Tools and Approaches: Risk Assessment Methods

*0288. VanCampen LE, Murphy WJ, Franks JR, Mathias PI, Toraason MA [2002]. Oxidative DNA damage is associated with intense noise exposure in the rat. Hear Res 164(1-2):29-38.

NORA: Disease and Injury: Fertility and Pregnancy Abnormalities

*0289. Vo E [2002]. A new technique to determine organic and inorganic acid contamination. The Analyst 127:178-182.

NORA: Disease and Injury: Allergic and Irritant Dermatitis, Research Tools and Approaches:

Control Technology and Personal Protective Equipment

*0290. Wallace ME, Fischbach TJ [2002]. Case studies: effectiveness of local exhaust for reducing welding fume exposure during boiler rehabilitation. Appl Occup Environ Hyg 17(3):145-151. NORA: Research Tools and Approaches: Control Technology and Personal Protective Equipment; Intervention Effectiveness Research

*0292. Wallace WE, Gupta NC, Hubbs AF, Mazza SM, Bishop HA, Keane MJ, Battelli LA, Ma J, Schleiff P [2002]. Cis-4-[18F]fluoro-L-proline PET imaging of pulmonary fibrosis in a rabbit model. J Nucl Med 43(3):413-420.

NORA: Research Tools and Approaches: Exposure Assessment Methods

*0294. Wang L, Antonini JM, Rojanasakul Y, Castranova V, Scabilloni JF, Mercer RR [2002]. Potential role of apoptotic macrophages in pulmonary inflammation and fibrosis. J Cell Physiol 194(2):215-224.

NORA: Work Environment and Workforce: Mixed Exposures

*0295. Wang L, Medan D, Mercer R, Shi X, Huang C, Castranova V, Ding M, Rojanasakul Y [2002]. Role of neutrophil apoptosis in vanadium-induced pulmonary inflammation in mice. $\mathrm{J}$ Environ Pathol Toxicol Oncol 21(4):343-350.

NORA: Work Environment and Workforce: Mixed Exposures

*0296. Wang ML, Li H, Seixas N, Ducatman A, Petsonk EL [2002]. Respiratory protection: associated factors and effectiveness of respirator use among underground coal miners. Am J Ind Med 42:55-62.

NORA: Research Tools and Approaches: Control Technology and Personal Protective Equipment

*0297. Ward E, Hurrell JJ, Colligan M [2002]. Ethical issues in occupational health research. Occup Med 17(4):637-655. 


\section{Journal Articles}

*0298. Warren GL, Hulderman T, Jensen N, McKinstry M, Mishra M, Luster MI, Simeonova PP [2002]. Physiological role of tumor necrosis factor $\alpha$ in traumatic muscle injury. FASEB J 16(12):1630-1632.

*0299. Wasserman DE, Hudock SD, Wasserman JF, Mullinix L, Wurzelbacher SJ, Siegfried KV [2002]. Hand-arm vibration in a group of hand-operated grinding tools. Hum Factors Ergon Manuf 12(2):211-226.

NORA: Disease and Injury: Musculoskeletal Disorders

*0300. Weissman DN [2002]. Epidemiology of asthma, severity matters [editorial]. Chest 121(1):6-8.

NORA: Disease and Injury: Asthma and Chronic Obstructive Pulmonary Disease

*0301. Weissman DN, Lewis DM [2002]. Allergic and latex-specific sensitization: route, frequency, and amount of exposure that are required to initiate IgE production. $\mathrm{J}$ Allergy Clin Immunol 110(2):S57-S63.

NORA: Disease and Injury: Asthma and Chronic Obstructive Pulmonary Disease

*0302. Weston A, Ensey J, Kreiss K, Keshava C, McCanlies E [2002]. Racial differences in prevalence of a supratypic HLA-genetic marker immaterial to pre-employment testing for susceptibility to chronic beryllium disease. Am J Ind Med 41(6):457-465.

NORA: Research Tools and Approaches: Risk Assessment Methods

*0303. Whelan EA, Grajewski B, Wood E, Kwan L, Nguyen M, Schnorr TM, Knecht EA, Kesner JS [2002]. Feasibility issues in reproductive biomonitoring of female flight attendants and teachers. J Occup Environ Med 44(10):947-955.

NORA: Disease and Injury: Fertility and Pregnancy Abnormalities; Research Tools and Approaches: Exposure Assessment Methods

*0305. Wilson ME, Rosewell KL, Kashon ML, Shughrue PJ, Merchenthaler I, Wise PM [2002]. Age differentially influences estrogen receptor- $\alpha(\operatorname{Er} \alpha)$ and estrogen receptor- $\beta(\operatorname{Er} \beta)$ gene expression in specific regions of the rat brain. Mech Ageing Dev 123(6):593-601.

*0306. Wu JZ, Dong RG, Rakheja S, Schopper AW [2002]. Simulation of mechanical responses of fingertip to dynamic loading. Med Eng Phys 24(4):253-264.

NORA: Disease and Injury: Musculoskeletal Disorders; Research Tools and Approaches: Control Technology and Personal Protective Equipment

*0307. Wu ZX, Satterfield BE, Fedan JS, Dey RD [2002]. Interleukin-1 $\beta$-induced airway hyperresponsiveness enhances substance $\mathrm{P}$ in intrinsic neurons of ferret airway. Am J Physiol Lung Cell Mol Physiol 283(5):L909-L917. 


\section{Journal Articles}

*0309. Wurzelbacher SJ, Hudock SD, Johnston OE, Blade LM, Shulman SA [2002]. Case studies: a pilot study on the effects of two ventilation methods on weld fume exposures in a shipyard confined space welding task. Appl Occup Environ Hyg 17(11):735-740.

NORA: Research Tools and Approaches: Control Technology and Personal Protective Equipment; Intervention Effectiveness Research

*0310. Yang XD, Ma JYC, Barger MW, Ma JKH [2002]. Transport and utilization of arginine and arginine-containing peptides by rat alveolar macrophages. Pharm Res 19(6):825-831. NORA: Work Environment and Workforce: Mixed Exposures

*0311. Yenchek MR, Cawley JC, Brautigam AL, Peterson JS [2002]. Distinguishing motor starts from short circuits through phase-angle measurements. IEEE Transactions on Industry Applications 38(1):195-202.

NORA: Research Tools and Approaches: Control Technology and Personal Protective Equipment

*0312. Yin XJ, Schafer R, Ma JYC, Antonini JM, Weissman DD, Siegel PD, Barger MW, Roberts JR, Ma JKH [2002]. Alteration of pulmonary immunity to Listeria monocytogenes by diesel exhaust particles (DEPs). 1. Effects of DEPs on early pulmonary responses. Environ Health Perspect 110(11):1105-1111.

NORA: Work Environment and Workforce: Mixed Exposures

*0313. Young SH, Robinson VA, Barger M, Zeidler P, Porter DW, Frazer DG, Castranova V [2002]. Modified endotoxin responses in rats pretreated with $1 \rightarrow 3-\beta$-glucan (zymosan A). Toxicol Appl Pharmacol 178(3):172-179.

NORA: Work Environment and Workforce: Mixed Exposures

*0314. Yucesoy B, Sleijffers A, Kashon M, Garssen J. deGruijl FR, Boland GJ, van Hattum J, Simeonova PP, Luster MI, van Loveren H [2002]. IL-1 $\beta$ gene polymorphisms influence hepatitis B vaccination. Vaccine 20(25-26):3193-3196.

*0315. Yucesoy B, Vallyathan V, Landsittel DP, Simeonova P, Luster MI [2002]. Cytokine polymorphisms in silicosis and other pneumoconioses. Mol Cell Biochem 234-235(1-2):219-224.

*0316. Zang LY, DeHaven J, Yocum A, Qiao G [2002]. Determination of alachlor and its metabolites in rat plasma and urine by liquid chromatography-electrospray ionization mass spectrometry. J Chromatogr B 767:93-101.

NORA: Disease and Injury: Allergic and Irritant Dermatitis

*0317. Zeise L, Hattis D, Andersen M, Bailer AJ, Bayard S, Chen C, Clewell H, Conolly R, Crump K, Dunson D, Finkel A, Haber L, Jarabek A, Kodell R, Krewski D, Thomas D, et al. 


\section{Journal Articles}

[2002]. Research opportunities in dose response modeling to improve risk assessment. Human Ecol Risk Assess 8(6):1421-1444.

NORA: Research Tools and Approaches: Risk Assessment Methods

*0318. Zhang XD, Murray DK, Lewis DM, Siegel PD [2002]. Dose-response and time course of specific IgE and IgG after single and repeated topical skin exposure to dry trimellitic anhydride powder in a Brown Norway rat model. Allergy 57(7):620-626.

NORA: Disease and Injury: Asthma and Chronic Obstructive Pulmonary Disease

*0319. Zhang XD, Siegel PD, Lewis DM [2002]. Immunotoxicology of organic acid anhydrides (OAAs). Int Immunopharmacol 2(2-3):239-248.

NORA: Disease and Injury: Asthma and Chronic Obstructive Pulmonary Disease

*0320. Zhang Z, Chen F, Huang C, Shi X [2002]. Vanadate induces $\mathrm{G}_{2} / \mathrm{M}$ phase arrest in p53deficient mouse embryo fibroblasts. J Environ Pathol Toxicol Oncol 21(3):223-231.

NORA: Research Tools and Approaches: Cancer Research Methods

*0321. Zhang Z, He H, Chen F, Huang C, Shi X [2002]. MAPKs mediate S phase arrest induced by vanadate through a p53-dependent pathway in mouse epidermal C141 cells. Chem Res Toxicol 15(7):950-956.

NORA: Research Tools and Approaches: Cancer Research Methods

*0322. Zhang Z, Huang C, Li J, Shi X [2002]. Vanadate-induced growth arrest is p53-dependent through activation of p21 in C141 cells. J Inorg Biochem 89(1-2):142-148.

NORA: Research Tools and Approaches: Cancer Research Methods

*0323. Zimmer AT [2002]. The influence of metallurgy on the formation of welding aerosols. J Environ Monit 4(5):628-632.

NORA: Research Tools and Approaches: Control Technology and Personal Protective Equipment

*0324. Zimmer AT, Baron PA, Biswas P [2002]. The influence of operating parameters on number-weighted aerosol size distribution generated from a gas metal arc welding process. $\mathrm{J}$ Aerosol Sci 33(3):519-531.

NORA: Research Tools and Approaches: Control Technology and Personal Protective Equipment

*0324a. Zimmer AT, Maynard AD [2002]. Investigation of the aerosols produced by a high-speed, hand-held grinder using various substrates. Ann Occup Hyg 46(8):663-672. NORA: Research Tools and Approaches: Control Technology and Personal Protective Equipment 


\section{BOOK CHAPTERS/PROCEEDINGS/ABSTRACTS/ TECHNICAL PAPERS/WEB}

*0325. Afshari A, Azadi S, Goldsmith T, Frazer D [2002]. A method to characterize aerosols produced by voluntary respiratory maneuvers [Abstract]. The Toxicologist 66(1-S):99. NORA: Disease and Injury: Asthma and Chronic Obstructive Pulmonary Disease; Work Environment and Workforce: Mixed Exposures

*0326. Afshari AA, McKinney W, Frazer DG [2002]. Design of a novel instrumentation for measurement of blood flow while gripping a handle. In: Proceedings of the Institute of Electrical and Electronics Engineers, Inc. (IEEE) 28th Annual Northeast Bioengineering Conference. Philadelphia, PA: pp. 215-216.

NORA: Disease and Injury: Musculoskeletal Disorders; Research Tools and Approaches: Control Technology and Personal Protective Equipment

*0327. Akpinar-Elci M, Elci OC, Odabasi A [2002]. Prevalence and risk factors of occupational asthma among florists in Turkey [Abstract]. Med Lav 93(5):449.

NORA: Disease and Injury: Asthma and Chronic Obstructive Pulmonary Disease

*0328. Akpinar-Elci M, Kanwal R, Kreiss K [2002]. Bronchiolitis obliterans syndrome in popcorn plant workers. In: Abstracts of the 2002 International Conference of the American Thoracic Society. Atlanta, GA: p. A526.

NORA: Disease and Injury: Asthma and Chronic Obstructive Pulmonary Disease

*0329. Al-Humadi NH, Siegel PD, Lewis DM, Barger MW, Ma JY, Weissman DN, Ma JK [2002]. Thiol and immune exposure dependent response to ovalbumin in sensitized rats [Abstract]. The Toxicologist 66(1-S):77.

NORA: Work Environment and Workforce: Mixed Exposures

*0330. Alterman T, Chen X, Grosch JG [2002]. Gender and occupational differences in blood pressure in the national health and nutrition examination survey III [Abstract]. J Women's Health Gend Based Med $I I(3): 322$.

NORA: Work Environment and Workforce: Organization of Work

*0331. Alterman T, Li J, Grosch JG [2002]. Job stressors and health among older workers in the 1998 health and retirement survey [Abstract]. Med Lav 93(5):414.

NORA: Work Environment and Workforce: Organization of Work 


\section{Book Chapters/Proceedings/Abstracts/Technical Papers/Web}

*0332. Ashley KE [2002]. Screening methods for metals monitoring in construction. In: Proceedings of the 12th Annual Construction Safety and Health Conference. Chicago, IL: Construction Safety Council, pp. 462-468.

NORA: Research Tools and Approaches: Exposure Assessment Methods

*0333. Bajpayee TS, Rehak TR, Mowrey GL, Ingram DK [2002]. A summary of fatal accidents due to flyrock and lack of blast area security in surface mining, 1989-1999. In: Proceedings of the 28th Annual Conference on Explosives and Blasting Technique. Vol. I. Cleveland, OH: International Society of Explosives Engineers, pp. 105-188.

*0334. Bang KM [2002]. Prevalence of asthma among U.S. working adults by industry and occupation. In: Proceedings of 2002 National Asthma Conference: Living Well with Asthma. Atlanta, GA: Centers for Disease Control and Prevention, National Center for Environmental Health, p. 34.

NORA: Disease and Injury: Asthma and Chronic Obstructive Pulmonary Disease

*0335. Bang KM, Weissman DN, Wagner GR [2002]. Tuberculosis in health care workers. In: Online Proceedings of the 30th Annual Meeting of American Public Health Association (APHA) Philadelphia, PA: [http://apha.confex.com/apha/130am/techprogram/meeting_130am.htm] NORA: Disease and Injury: Infectious Diseases

*0336. Barczak TM, Conover DP [2002]. The NIOSH shield hydraulics inspection and evaluation of leg data (SHIELD) computer program. In: Proceedings of the 21st International Conference on Ground Control in Mining. Morgantown, WV: West Virginia University, pp. 27-38.

NORA: Research Tools and Approaches: Control Technology and Personal Protective Equipment

*0337. Barczak TM, Smith R [2002]. Investigation of the jacking force capability of tunnel liners. SME preprint 02-186. Littleton, CO: Society for Mining, Metallurgy, and Exploration, Inc., pp. 1-17.

NORA: Research Tools and Approaches: Control Technology and Personal Protective Equipment

*0338. Bartley DL, Irwin K [2002]. Accuracy in measurements using diffusive samplers. In: Proceedings of the International Conference Measuring Air Pollutants by Diffusive Sampling. Montpellier, France: European Commission, pp. 99-107.

NORA: Research Tools and Approaches: Exposure Assessment Methods

*0339. Berardinelli S, Fotta S, Hayes J, Moyer E [2002]. Real-time HVAC filter efficiency testing using optical particle counters. In: Abstracts of the 2002 American Industrial Hygiene Conference and Exposition. San Diego, CA: p. 25.

NORA: Research Tools and Approaches: Control Technology and Personal Protective Equipment 


\section{Book Chapters/Proceedings/Abstracts/Technical Papers/Web}

*0340. Berardinelli S, Fotta S, Hayes J, Moyer E [2002]. Real-time HVAC filter efficiency testing using optical particle counters. In: Proceedings of the 9th International Conference on Indoor Air Quality and Climate. Santa Cruz, CA: p. 76.

NORA: Research Tools and Approaches: Control Technology and Personal Protective Equipment

*0341. Berardinelli S, Lawrence R, Coffey C, Kullman G, Moyer E [2002]. Performance of selected N95 and P100 respirator filters to plant aerosols at a snack food production facility. In: Abstracts of the 2002 American Industrial Hygiene Conference and Exposition. San Diego, CA: p. 98.

NORA: Research Tools and Approaches: Control Technology and Personal Protective Equipment

*0342. Bobick T [2002]. Overview of deaths and injuries caused by falls through roof and floor openings and surfaces, including skylights. In: Proceedings of the 12th Annual Construction Safety and Health Conference and Exposition. Chicago, IL: Construction Safety Council, p. 370.

*0343. Bockosh GR, Fotta B, McKewan WM [2002]. Employment, production, and fatality trends in the U.S. coal mining industry. Coal Age 107(10):18-20.

*0343a. Boeniger M [2002]. Chemical protective clothing and the skin: practical considerations. 2nd ed., Fairfax, VA: AIHA Press, pp. 1-48.

NORA: Disease and Injury: Allergic and Irritant Dermatitis

*0344. Boord L, Dower J [2002]. The NIOSH CBRN respiratory protection standards update. In: Abstracts of the Eleventh Conference of the International Society for Respiratory Protection.

Edinburgh, Scotland. [http://isrp.com.au]

*0345. Booth-Butterfield S [2002]. A message-based campaign for the adoption of new NIOSH methods for field portable instruments. In: Proceedings of the 2002 American Industrial Hygiene Conference and Exposition. San Diego, CA: FM 205.

*0346. Boylstein R, Piacitelli C, Kullman G, Jones W, Heitbrink W [2002]. Engineering control of airborne contaminants at a microwave popcorn packaging plant. In: Abstracts of the 2002 American Industrial Hygiene Conference and Exposition. San Diego, CA: p. 36.

NORA: Research Tools and Approaches: Control Technology and Personal Protective Equipment

*0347. Byrne DC [2002]. The consequences of 'leaky' enclosures. Sound and Vibration Jan:36-38.

NORA: Research Tools and Approaches: Control Technology and Personal Protective Equipment

*0348. Calvert GM [2002]. Occupational silica exposure and risk of various diseases: an analysis using death certificates from 27 States [Abstract]. Med Lav 93(5):472. 


\section{Book Chapters/Proceedings/Abstracts/Technical Papers/Web}

*0349. Calvert GM, Sanderson WT, Barnett M, Blondell JM, Mehler LN, Sanderson WT [2002]. Surveillance of pesticide-related illness and injury in humans. In: Handbook of Pesticide Toxicology, 2nd ed. San Diego, CA: Academic Press, pp. 603-641.

*0350. Campbell D, Coffey C, Zhuang Z, Jensen P [2002]. Reducing respirator fit-test errors: a multi-donning approach. In: Abstracts of the 2002 American Industrial Hygiene Conference and Exposition. San Diego, CA: p. 97.

NORA: Research Tools and Approaches: Control Technology and Personal Protective Equipment

*0351. Carreón T, Ruder AM, Schulte PA, Hayes RB, Rothman N, LeMasters GK, Waters M, Grant DJ, Boissy R, Bell DA, Kadlubar FF, Hemstreet GP, Yin S, Li G, Feng P [2002]. NAT2 slow acetylation and bladder cancer in workers exposed to benzidine. In: Proceedings of the American Association for Cancer Research, San Francisco, CA: Vol. 43, p. 938.

NORA: Research Tools and Approaches: Cancer Research Methods

*0352. Castranova V, Millecchia L, Porter DW, Robinson VA, Willard P, Hubbs AF, Ramsey D, McLaurin J, Khan A, Teass A [2002]. Enhanced nitric oxide production associated with silicainduced disease in rats [Abstract]. FASEB J 16(5):A962.

*0353. Castranova V, Porter DW, Willard P, Hubbs AF, Millecchia L [2002]. Time course of pulmonary responses to inhalation of crystalline silica in the rat model: evidence for a threshold burden beyond which silicosis progresses without further exposure [Abstract]. Med Lav (Suppl) 93:S39.

*0354. Cawley JC [2002]. Electrical accidents in the mining industry, 1990-1999. SME preprint 02-007. Littleton, CO: Society for Mining, Metallurgy, and Exploration, Inc., pp. 1-7.

NORA: Research Tools and Approaches: Control Technology and Personal Protective Equipment

*0355. Cecala AB, Organiscak JA, Heitbrink WA, Zimmer JA, Fisher T, Gresh RE, Ashley JD [2002]. Reducing enclosed cab drill operators' respirable dust exposure at surface coal operations with a retrofitted filtration and pressurization system. SME preprint 02-105. Littleton, CO: Society for Mining, Metallurgy, and Exploration, Inc., pp. 1-6.

NORA: Research Tools and Approaches: Control Technology and Personal Protective Equipment

*0356. Cecala AB, Organiscak JA, Page SJ, Thimons ED [2002]. Reducing silica exposure in aggregate operations. Agg Man Jan:24-28.

NORA: Research Tools and Approaches: Control Technology and Personal Protective Equipment

*0357. Cecala AB, Organiscak JA, Timko RJ, Colinet JF, Thimons ED, Heitbrink WA [2002]. Reducing silica exposure to miners at surface operations in the United States [Abstract]. Med Lav (Suppl) 93:S42.

NORA: Research Tools and Approaches: Control Technology and Personal Protective Equipment 


\section{Book Chapters/Proceedings/Abstracts/Technical Papers/Web}

*0358. Cezeaux JL, Lindsley WG, Wiseman L [2002]. Effects of vibration on vascular permeability in rats. In: Proceedings of the 21st Biomedical Engineering: Recent Developments. Washington, DC: Medical and Engineering Publishers, Inc., pp. 213-214.

NORA: Disease and Injury: Musculoskeletal Disorders; Research Tools and Approaches: Control Technology and Personal Protective Equipment

*0359. Chase FE, Mark C, Heasley KA [2002]. Deep cover pillar extraction in the U.S. coalfields. In: Proceedings of the 21st International Conference on Ground Control in Mining. Morgantown, WV: West Virginia University, pp. 68-80.

NORA: Research Tools and Approaches: Control Technology and Personal Protective Equipment

*0360. Chekan GJ, Colinet JF, Grau RH III [2002]. Silica dust sources in underground metal/nonmetal mines: two case studies. SME preprint 02-037. Littleton, CO: Society for Mining, Metallurgy, and Exploration, Inc., pp. 1-8.

NORA: Research Tools and Approaches: Control Technology and Personal Protective Equipment

*0361. Chen BT, Keswani J, Zhou G, Ong T [2002]. Using PCR to detect indoor fungi. In: Proceedings of the 9th International Conference on Indoor Air Quality and Climate. Santa Cruz, CA: pp. 63-68.

NORA: Research Tools and Approaches: Exposure Assessment Methods

*0362. Chen F, Zhang Z, Bower J, Lu Y, Leonard SS, Ding M, Castranova V, Piwnica-Worms $\mathrm{H}$, Shi X [2002]. Arsenite-induced Cdc25C degradation is through the KEN-box and ubiquitinproteasome pathway. In: Proceedings of the National Academy of Sciences of the United States of America. Washington, DC: PNAS 99(4):1990-1995.

NORA: Research Tools and Approaches: Cancer Research Methods

*0363. Chiou S, Pan CS [2002]. Ergonomic walkthrough evaluation of drywall tasks. In: Proceedings of the 12th Annual Construction and Safety and Health Conference and Exposition. Chicago, IL: Construction Safety Council, p. 335.

NORA: Disease and Injury: Traumatic Injuries; Research Tools and Approaches: Control Technology and Personal Protective Equipment

*0364. Clerval CD, Vivekanandan B, De Feo AP, El-Fawal HA, O'Callaghan JP [2002]. Autoantibodies to nervous system proteins following trimethyl tin (TMT) exposure: a comparison of elisa and western-blot analysis [Abstract]. The Toxicologist 66(1-S):210.

*0365. Coffey CC, Lawrence RB, Campbell DL, Zhuang Z, Calvert C, Jensen PA, Hudnall J [2002]. Performance of eighteen N95 filtering-facepiece models. In: Abstracts of the 2002 American Industrial Hygiene Conference and Exposition. San Diego, CA: p. 46.

NORA: Research Tools and Approaches: Control Technology and Personal Protective Equipment 


\section{Book Chapters/Proceedings/Abstracts/Technical Papers/Web}

*0366. Coffey CC, Martin SB, Lawrence RB, Calvert CA, Berardinelli SP, Jensen PA, Jones WG [2002]. Examination of the physical and chemical nature of used ventilation filters and collected particulate matter In: Proceedings of the 9th International Conference on Indoor Air Quality and Climate. Santa Cruz, CA: p. 1026.

NORA: Research Tools and Approaches: Control Technology and Personal Protective Equipment

*0367. Coleman PJ [2002]. The role of total mining experience on mining injuries and illnesses in the United States. In: Proceedings of the China International Forum on Work Safety. Beijing, China: State Administration of Work Safety (SAWS), pp. 331-336.

*0368. Colinet JF, Chekan GJ, Listak JM, Rider JP [2002]. Ventilation impacts on respirable dust control. In: Proceedings of the North American/Ninth U.S. Mine Ventilation Symposium. Lisse, The Netherlands: Balkema, pp. 565-572.

NORA: Research Tools and Approaches: Control Technology and Personal Protective Equipment

*0369. Colinet JF, Thimons ED [2002]. Improving silica dust control through targeted research. SME preprint 02-189. Littleton, CO: Society for Mining, Metallurgy, and Exploration, Inc., pp. 1-6.

NORA: Research Tools and Approaches: Control Technology and Personal Protective Equipment

*0370. Cox-Ganser JM, Rao CY, Kreiss K [2002]. Work-related asthma symptoms correlate with environmental measures in a healthcare facility. In: Proceedings of the 9th International Conference on Indoor Air Quality and Climate. Santa Cruz, CA: pp. 365-370.

NORA: Disease and Injury: Asthma and Chronic Obstructive Pulmonary Disease

*0371. Davis KG, Marras WS, Waters TR [2002]. Relative contributions of workplace factors and individual characteristics in the development of spine loads. In: Proceedings of the 46th Annual Human Factors and Ergonomics Society Meeting. Baltimore, MD: pp. 1066-1070. NORA: Disease and Injury: Musculoskeletal Disorders

*0372. Depree GJ, Siegel PD, Bledsoe TA, Lewis DM [2002]. Determination of dialkyldithiocarbamate accelerator residues in latex condoms [Abstract]. FASEB J 16(5):A958.

*0372a. Dewan PK, Fry AM, Laserson K, Tierney BC, Quinn CP, Hayslett JA, Broyles LN, Shane A, Winthrop KL, Walks I, Siegel L, Hales T, Semenova VA, Romero-Steiner S, Elie C, Khabbaz R, Anthrax Response Team. [2002]. Inhalational anthrax outbreak among postal workers, Washington, D.C., 2001. Emerg Infect Dis 8(10):1066-1072.

*0373. Ding M, Lu Y, Bowman L, Huang C, Castranova V [2002]. Activation of protein kinase $\mathrm{C}$ is required for silica-induced activation of the MAP kinase-AP-1 pathway [Abstract]. Med Lav (Suppl) 93:S41. 


\section{Book Chapters/Proceedings/Abstracts/Technical Papers/Web}

*0374. Doney B, Groce DW, Day B [2002]. Focus groups on respiratory use among the society for protective coatings (SSPC) members, conducted by NIOSH. In: Abstracts of the 2002 American Industrial Hygiene Conference and Exposition. San Diego, CA: p. 98.

NORA: Research Tools and Approaches: Control Technology and Personal Protective Equipment

*0375. Dong RG, McDowell TW, Welcome D, Wu JZ, Warren C, Smutz WP, Schopper AW [2002]. Mechanical energy absorption in human fingers exposed to hand-transmitted vibration. In: Proceedings of the 21st Biomedical Engineering: Recent Developments. Washington, DC: Medical and Engineering Publishers, Inc., pp. 159-160.

NORA: Disease and Injury: Musculoskeletal Disorders; Research Tools and Approaches: Control Technology and Personal Protective Equipment

*0376. Drake PL [2002]. Measuring airborne metals at mining sites using portable instruments: advantages and potential problems. In: Abstracts of the 2002 American Industrial Hygiene Conference and Exposition. San Diego, CA: p. 205.

*0377. Drake PL [2002]. Portable monitors for airborne lead at mining sites. In: Abstracts of the 2002 American Industrial Hygiene Conference and Exposition. San Diego, CA: p. 28.

*0378. Edwards JC, Franks RA, Friel GF, Lazzara CP, Opferman JJ [2002]. In-mine evaluation of discriminating mine fire sensors. In: Proceedings of the North American/Ninth U.S. Mine Ventilation Symposium. Lisse, The Netherlands: Balkema, pp.527-532.

NORA: Work Environment and Workforce: Emerging Technologies

*0379. El-Ayouby N, Gao P, Wassell JT, Hall RC [2002]. Effect of cycles of contamination and decontamination on chemical glove performance. In: Proceedings of the International Conference on Occupational and Environmental Exposures of Skin to Chemicals: Science and Policy. Washington, DC: National Institute for Occupational Safety and Health (NIOSH), p. 13.

*0379a. Elci OC, Akpinar-Elci M, Blair A, Dosemeci M [2002]. Occupational exposures and the risk of laryngeal cancer in Turkey [Abstract]. Med Lav 93(5):374.

NORA: Research Tools and Approaches: Risk Assessment Methods

*0380. Elliott LJ, Katz T, Neton J, Schubauer-Berigan M [2002]. United States energy employees occupational illness compensation program: adjudication of radiation-related cancer claims utilizing dose reconstruction and probability of causation claims. In: Proceedings of the International Conference on Occupational Radiation Protection: Protecting Workers Against Exposure to Ionizing Radiation. Geneva, Switzerland: International Atomic Energy Agency (IAEA), IAEABCN 91, pp. 572-575.

*0381. Ensell MX, Reynolds SH, Jefferson AM, Lowry DT, Kashon ML, Tyson FL, Senft JR, Sargent LM [2002]. Non-random chromosomal changes in high and low invasive tumor cells 


\section{Book Chapters/Proceedings/Abstracts/Technical Papers/Web}

derived from early passage mouse lung adenocarcinoma cell cultures [Abstract]. Am Assoc Cancer Res 43:634.

*0382. Eppley D, Reinke DC [2002]. Pennsylvania incorporates innovative programs into mine rescue training. MSHA Holmes Safety Association Bulletin Feb-Mar: pp.15-16.

*0383. Etherton J [2002]. Safety related machinery controls for maintenance risk reduction. In: Proceedings of American Society of Safety Engineers Professional Development Conference. Nashville, TN: Audio CD/Tape 624.

NORA: Disease and Injury: Traumatic Injuries

*0384. Fedan JS, Dowdy J, Reasor MJ, Van Scott MR, Johnston RA [2002]. Epitheliumdependent relaxation responses of guinea-pig isolated, perfused trachea to hypertonic solution involves carbon monoxide (CO) [Abstract]. Am J Respir Crit Care Med 165(8):A65.

*0385. Fedan JS, Wu D, Van Scott MR [2002]. Differences in bioelectric responses to hyperosmolarity in epithelium of fresh tracheal segments (FE) and air-liquid interface epithelial cell cultures (CE) from guinea pigs [Abstract]. The Pharmacologist 44(2)(Suppl 1):A226.

*0386. Filios M, Schill DP, Valiante D, Flattery J, Harison R, Davis L, Tumpowsky CM, Pechter E, Reilly MJ, Rosenman RD [2002]. State-based surveillance for work- related asthma: 7 years of SENSOR data, 1993-1999. In: Online Proceedings of the 30th Annual Meeting of American Public Health Association [http://apha.confex.com/apha/130am/techprogram/

meeting_130am.htm]

NORA: Disease and Injury: Asthma and Chronic Obstructive Pulmonary Disease

*0387. Frasch HF [2002]. A random walk model of stratus stratum corneum diffusion. In: The Essential Stratum Corneum. Chapter 25. London: Martin Dunitz Publishers, pp. 159-161. NORA: Research Tools and Approaches: Exposure Assessment Methods

*0388. Frazer D, McKinney W, Stolarik B, Reynolds J, Rosenberry K, Afshari A [2002]. Effects of whole body vibration on pulmonary function in rats. In: Proceedings of the 21 st Biomedical Engineering: Recent Developments. Washington, DC: Medical and Engineering Publishers, Inc., pp. 365-366.

NORA: Work Environment and Workforce: Mixed Exposures; Research Tools and Approaches: Exposure Assessment Methods

*0389. Frazer D, Stolarik B, McKinney W, Stone S, Afshari A, Goldsmith T, Barkley J, Reynolds J, Weber K [2002]. Differences in airflow patterns during voluntary coughs that result from obstructive lung disease. In: Proceedings of the 21st Biomedical Engineering: Recent 


\section{Book Chapters/Proceedings/Abstracts/Technical Papers/Web}

Developments. Washington, DC: Medical and Engineering Publishers, Inc., pp. 317-318. NORA: Disease and Injury: Asthma and Chronic Obstructive Pulmonary Disease; Work Environment and Workforce: Mixed Exposures

*0390. Friel GF, Edwards JC [2002]. Neural network application to mine fire diesel exhaust discrimination. In: Proceedings of the North American/Ninth U.S. Mine Ventilation Symposium. Lisse, The Netherlands: Balkema, pp. 533-538.

NORA: Work Environment and Workforce: Emerging Technologies

*0391. Gallagher S, Marras WS, Davis KG [2002]. Effects of load and posture on the recruitment of trunk muscles. In: Proceedings of the Human Factors and Ergonomics Society 46th Annual Meeting. Santa Monica, CA: pp. 1071-1075. NORA: Disease and Injury: Low Back Disorders; Research Tools and Approaches: Control Technology and Personal Protective Equipment

*0392. Gallagher S, Unger RL [2002]. Strength demands of line handlers on the Panama Canal. In: Abstracts of the 2002 American Industrial Hygiene Conference and Exposition. San Diego, CA: p. 59.

NORA: Research Tools and Approaches: Control Technology and Personal Protective Equipment

*0392a. Gao N, Keane MJ, Ong T, Ye J, Martin J, Miller WE, Wallace WE [2002]. Respirable quartz and kaolin alumino-silicate induction of in vitro cytotoxicity and apoptosis in the presence of surfactant or serum: caveats to bioassay interpretation. In: Proceedings of Inhaled Particles IX. Cambridge, UK: Ann Occup Hyg 46:50-52.

NORA: Work Environment and Workforce: Mixed Exposures; Research Tools and Approaches: Exposure Assessment Methods

*0393. Garcia F, Diamond WP, Marshall JK [2002]. Remote gob gas venthole monitoring and cellular telephone-based real-time data transmission system. In: Proceedings of the North American/Ninth U.S. Mine Ventilation Symposium. Lisse, The Netherlands: Balkema, pp. 323-327.

*0394. Goe S, Filios M [2002]. SENSOR occupational lung disease bulletin, March 2002: the recognition and management of work-aggravated asthma. Boston, MA: Massachusetts Department of Public Health, Occupational Health Surveillance Program, pp. 1-4. NORA: Disease and Injury: Asthma and Chronic Obstructive Pulmonary Disease

*0395. Goe S, Henneberger PK [2002]. A descriptive study of work-aggravated asthma. In: Abstracts of the 2002 International Conference of the American Thoracic Society. Atlanta, GA: p. A526.

NORA: Disease and Injury: Asthma and Chronic Obstructive Pulmonary Disease 


\section{Book Chapters/Proceedings/Abstracts/Technical Papers/Web}

*0396. Goodman GVR, Organiscak JA [2002]. An evaluation of methods for controlling silica dust exposures on roof bolters. SME preprint 02-163. Littleton, CO: Society for Mining, Metallurgy, and Exploration, Inc., pp. 1-5.

NORA: Research Tools and Approaches: Control Technology and Personal Protective Equipment

*0397. Grau RH III, Mucho TP, Robertson SB, Smith AC, Garcia F [2002]. Practical techniques to improve the air quality in underground stone mines. In: Proceedings of the North American/Ninth U.S. Mine Ventilation Symposium. Lisse, The Netherlands: Balkema, pp. 123-129.

NORA: Research Tools and Approaches: Control Technology and Personal Protective Equipment

*0398. Grau RH III, Robertson SB, Mucho TP, Garcia F, Smith AC [2002]. NIOSH ventilation research addressing diesel emissions and other air quality issues in nonmetal mines. SME preprint 02-187. Littleton, CO: Society for Mining, Metallurgy, and Exploration, Inc., pp. 1-7. NORA: Research Tools and Approaches: Control Technology and Personal Protective Equipment

*0399. Greskevitch M, Middendorf P, Castranova V, Ahlers H, Hearl F [2002]. Blasting abrasives: health hazard comparison [Abstract]. Med Lav (Suppl) 93:S42-S43.

NORA: Research Tools and Approaches: Exposure Assessment Methods

*0400. Hales TR [2002]. Ergonomics and upper extremity musculoskeletal disorders, physical and biological hazards of the workplace. In: Physical and Biological Hazards of the Workplace. 2nd ed. New York: Wiley Interscience Publishers, pp. 19-49.

*0401. Hall I, Gregory EW, Wirth O, Lindsley WG, Cutlip RG [2002]. Spectral analysis of physiological force tremor during dynamic movements of rat skeletal muscle. In: Proceedings of the 21st Biomedical Engineering: Recent Developments. Washington, DC: Medical and Engineering Publishers, Inc., pp. 11-12.

*0402. Harris GK, Zhang Z, Shi X [2002]. Effects of the lung carcinogen silica on cyclooxygenase2 and prostaglandin E2 expression in RAW 264.7 cells [Abstract]. Cancer Res 43:470.

NORA: Research Tools and Approaches: Cancer Research Methods

*0403. Hartley D, Biddle E, Grosch JW, Marsh S [2002]. The burden of occupational fatal injury for older workers in the United States. In: Injury Insights June/July 2002. Itasca, IL: National Safety Council Research and Statistical Services, pp. 1-2, 11.

NORA: Work Environment and Workforce: Special Populations at Risk

*0404. Heasley KA, Ellenberger JL, Jeran PW [2002]. Microseismic activity associated with a deep longwall coal mine. SME preprint 02-175. Littleton, CO: Society for Mining, Metallurgy, and Exploration, Inc., pp. 1-5.

*0405. Henneberger P, Derk S, Davis L, Tumpowsky C, Reilly M, Rosenman K, Schill D, Valiante D, Flattery J, Harrison R, Filios M [2002]. Work-related reactive airways dysfunction 


\section{Book Chapters/Proceedings/Abstracts/Technical Papers/Web}

syndrome in selected U.S. states. In: Abstracts of the International Conference of the American Thoracic Society. Atlanta, GA: p. A526.

NORA: Disease and Injury: Asthma and Chronic Obstructive Pulmonary Disease

*0406. Henneberger P, Reilly M, Rosenman K, Schil D, Valiante D, Flattery J, Harrison R, Davis L, Tumpowsky C, Filios MS [2002]. A descriptive study of work-aggravated asthma. In: Abstracts of the International Conference of the American Thoracic Society. Atlanta, GA: p. A526.

NORA: Disease and Injury: Asthma and Chronic Obstructive Pulmonary Disease

*0407. Henneberger PK, Deubner D, Veililla A, Kreiss K [2002]. Do indicators of beryllium skin exposure predict beryllium sensitization? In: Abstracts of the 12th Annual Congress of the European Respiratory Society. European Respiratory Journal (Suppl). Stockholm, Sweden: p. 3223.

NORA: Research Tools and Approaches: Exposure Assessment Methods

*0408. Henneberger PK, Goe SK, Doney B, Groce DW [2002]. Industries in which workers are at risk for beryllium exposure [Abstract]. Med Lav 93(5):465.

NORA: Research Tools and Approaches: Exposure Assessment Methods

*0409. Hewett D [2002]. Investigation of asbestos exposures associated with vermiculite expansion and vermiculite use in production of industrial and horticultural products. In: Abstracts of the 2002 American Industrial Hygiene Conference and Exposition. San Diego, CA: p. 51.

NORA: Research Tools and Approaches: Exposure Assessment Methods

*0410. Hewett P [2002]. Equations for calculating exposure management objectives for single shift, long-term averaging and dual exposure limits. In: Abstracts of the 2002 American Industrial Hygiene Conference and Exposition. San Diego, CA: p. 52.

NORA: Research Tools and Approaches: Exposure Assessment Methods

*0411. Hines RN, Ma Q, Andrews GK, Mirkes PE [2002]. Alterations in gene expression as a mechanism of toxicant action [Abstract]. The Toxicologist 66(1-S):1.

*0412. Hnizdo E, Chen IQ, Attfield M, Chen W, Wallace W [2002]. Comparison of risk of silicosis in Chinese tin miners, tungsten miners and pottery workers and South African gold miners. Med Lav (Suppl) 93:S27.

NORA: Disease and Injury: Asthma and Chronic Obstructive Pulmonary Disease

*0413. Hnizdo E, Sullivan PA, Bang KM, Wagner G [2002]. US population prevalence, odds ratio and attributable fraction of airflow obstruction and employment by industry - a study of NHANES III data [Abstract]. Am J Epidemiol 155(11)(Suppl):S77.

NORA: Disease and Injury: Asthma and Chronic Obstructive Pulmonary Disease 


\section{Book Chapters/Proceedings/Abstracts/Technical Papers/Web}

*0414. Hoffman C, Henneberger P, Toren K [2002]. Exposure to ozone and other irritant gasses in pulp mills and the onset of rhinitis. In: Abstracts of the 2002 International Conference of the American Thoracic Society. Atlanta, GA: p. A526.

NORA: Research Tools and Approaches: Exposure Assessment Methods

*0415. Homce GT, Cawley JC, Sacks HK, Yenchek MR [2002]. Heavy equipment near overhead power lines? New safety research may save your life. Eng Min J 203(4):36-39. NORA: Research Tools and Approaches: Control Technology and Personal Protective Equipment; Disease and Injury: Traumatic Injuries

*0416. Hoover M [2002]. A multiple-frame-of-reference scheme for assigning appropriate rotameter correction factors. In: Abstracts of the 2002 American Industrial Hygiene Conference and Exposition. San Diego, CA: p. 86.

NORA: Research Tools and Approaches: Exposure Assessment Methods

*0417. Hoover M, McCawley M, Yereb D, Tinkle S, Beaton S, French P [2002]. Field evaluation of a LIBS sampler for determining surface contamination due to beryllium. In: Abstracts of the 2002 American Industrial Hygiene Conference and Exposition. San Diego, CA: p. 91.

NORA: Research Tools and Approaches: Exposure Assessment Methods

*0417a. Hsu VP, Lukacs SL, Handzel T, Hayslett J, Harper S, Hales T, Semenova VA, RomeroSteiner S, Elie C, Quinn CP, Khabbaz R, Khan AS, Martin G, Eisold J, Schuchat A, Hajjeh RA [2002]. Opening a Bacillus anthracis-containing envelope, Capitol Hill, Washington, DC: the public health response. Emerg Infect Dis 8(10):1039-1043.

*0418. Hu S, Barger M, Ma JYC, Ma JKH [2002]. The involvement of mitochondria in silicainduced apoptosis of pulmonary phagocytes [Abstract]. AAPS Pharm Sci 4(4):M1086.

[http://www.aapspharmaceutica.com/search/abstract_view.asp?id=4518]

*0419. Hubbs A, Castranova V, Jones W, Porter D, Goldsmith W, Kullman G, Battelli L, Friend S, Mercer RR, Schwegler-Berry D, Kreiss K [2002]. Workplace safety and food ingredients: the example of butter flavoring [Abstract]. In: Proceedings of the 224th American Chemical Society (ACS) National Meeting. Boston, MA: AGFD-148.

NORA: Work Environment and Workforce: Mixed Exposures

*0420. Hubbs AF, Mercer RR, Battelli L, Friend S, Schwegler-Berry D, Castranova V, Kreiss K, Kullman G, Frazer D, Goldsmith WT, Jones WG [2002]. Ultrastructural changes in the airways of rats inhaling butter flavoring vapors [Abstract]. The Toxicologist 66(1-S):194.

NORA: Work Environment and Workforce: Mixed Exposures 


\section{Book Chapters/Proceedings/Abstracts/Technical Papers/Web}

*0421. Iannacchione AT, Coyle PR [2002]. An examination of the Loyalhanna limestone's structural features and their impact on mining and ground control practices. In: Proceedings of the 21st International Conference on Ground Control in Mining. Morgantown, WV: West Virginia University, pp. 218-227.

NORA: Disease and Injury: Traumatic Injuries

*0422. Iannacchione AT, Dolinar DR, Mucho TP [2002]. High-stress mining under shallow overburden in underground U.S. stone mines. In: Proceedings of the First International Seminar on Deep and High-Stress Mining. Nedlands, Australia: Australian Centre for Geomechanics, section 32.

NORA: Disease and Injury: Traumatic Injuries

*0423. Inman C, Blanciforti L [2002]. Observed versus reported behaviors and a theoreticallybased eye injury intervention for carpenters. In: Injury Insights, December 2002-January 2003. Itasca, IL: National Safety Council Research and Statistical Services, pp. 1-2, 7.

*0424. Iverson SR [2002]. Investigation of bulk solids engineering properties and application of PFC2D to ore pass flow problems. In: Numerical modeling in micromechanics via particle methods. In: Proceedings of the 1st International PFC Symposium. Rotterdam, The Netherlands: Balkema, pp. 252-258.

*0425. Jackson LL, Line J [2002]. Work-related injury statistics query system (Work-RISQS). [http://www2.cdc.gov/risqs/default.asp]

*0428. Jensen P, Moyer E, Berardinelli S, Hayes J, Fotta F [2002]. Evaluation of alternative HVAC filters: effect on flow rate, capital expense, maintenance costs, and energy consumption considerations. In: Abstracts of the 2002 American Industrial Hygiene Conference and Exposition. San Diego, CA: p. 101.

NORA: Research Tools and Approaches: Control Technology and Personal Protective Equipment

*0428a. Jernigan DB, Raghunathan PL, Bell BP, Brechner R, Bresnitz EA, Butler JC, Cetron M, Kohen M, Doyle T, Fischer M, Greene C, Griffith KS, Guarner J, Hadler JL, Hayslett JA, National Anthrax Epidemiologic Investigation Team [2002]. Investigation of bioterrorismrelated anthrax, United States, 2001: epidemiologic findings. Emerg Infect Dis [serial online]. Available from: URL: http://www.cdc.gov/ncidod/EID/vol8no10/02-0353.htm NORA: Disease and Injury: Infectious Diseases

*0429. Jorgensen MJ, Marras WS, Waters TR [2002]. The effect of a variable lumbar erector spinae sagittal plane moment arm on predicted spinal loading. In: Proceedings of the 46th Annual Human Factors and Ergonomics Society Meeting. Baltimore, MD: pp. 1061-1065. NORA: Disease and Injury: Musculoskeletal Disorders 


\section{Book Chapters/Proceedings/Abstracts/Technical Papers/Web}

*0430. Joseph P, Lei Y, Ong T [2002]. Antisense inhibition of translation elongation factor-1 delta reverses the oncogenic potential of cadmium transformed cells [Abstract]. The Toxicologist 66(1-S):115.

NORA: Research Tools and Approaches: Cancer Research Methods

*0431. Joseph P, Lei Y-X, Whong W-Z, Ong T [2002]. Oncogenic potential of mouse translation elongation factor-1 delta, a novel cadmium-responsive proto-oncogene. In: Proceedings of American Association for Cancer Research 43:1033.

NORA: Research Tools and Approaches: Cancer Research Methods

*0431a. Kain B, Porter D, Blemings KP, Klandorf H [2002]. Dietary potassium oxanate increases uric acid in rat plasma and bronchoalveolar lavage fluid. [Abstract]. FASEB J 16(5):A963.

*0432. Keane M, Gao N, Wallace W [2002]. Apoptosis induction in vitro and in vivo by quartz and kaolin dusts [Abstract]. Med Lav 93:S40.

NORA: Work Environment and Workforce: Mixed Exposures; Research Tools and Approaches: Exposure Assessment Methods

*0433. Keane M, Martin J, Hornsby-Myers J, Stephens J, Harrison J, Myers J, Ong T, Wallace W [2002]. Particle characterization, free radical generation, and genotoxicity of hard metal and detonation coating dusts. In: Proceedings of Inhaled Particles IX. Cambridge UK: Ann Occup Hyg 46(Suppl 1):402-405.

NORA: Work Environment and Workforce: Mixed Exposures; Research Tools and Approaches: Exposure Assessment Methods

*0434. Keshava N, Huffman D, Wu ZL, Ong T [2002]. Alterations in methylation patterns in human lung cancer tissues. In: Proceedings of American Association for Cancer Research, 43:1123.

NORA: Research Tools and Approaches: Cancer Research Methods

*0435. Keshava N, Huffman D, Wu ZL, Ong T [2002]. Global profiling of methylation status in lung cancer tissues [Abstract]. Env Molecul Mutagen 39(Suppl 33):35.

NORA: Research Tools and Approaches: Cancer Research Methods

*0436. Keshava N, Ong T [2002]. Gene expression patterns in normal human liver cells exposed to tetrachloroethylene using microarray analysis [Abstract]. Env Molecul Mutagen 39(Suppl 33):35. NORA: Research Tools and Approaches: Cancer Research Methods

*0437. Keswani J, Chen BT [2002]. Evaluation of PCR interference from dust samples for monitoring indoor environments. In: Abstracts of the 2002 Annual Conference of the American Society for Microbiology. Salt Lake City, UT: p 452.

NORA: Research Tools and Approaches: Exposure Assessment Methods 


\section{Book Chapters/Proceedings/Abstracts/Technical Papers/Web}

*0438. Key-Schwartz RJ, Ramsey DM [2002]. Silver-coated capillary pore filters for crystalline silica analysis [Abstract]. Med Lav 93:S21.

NORA: Research Tools and Approaches: Exposure Assessment Methods

*0439. Kinneer KL, Ye J, Ma Q [2002]. Inhibition of TNF $\alpha$ promoter/enhancer activity by phenolic antioxidants [Abstract]. The Toxicologist 66(1-S):355.

*0440. Kissell FN, Volkwein JC [2002]. Improving ventilation in underground stone mines. Agg Man 1(1):20-25.

NORA: Research Tools and Approaches: Exposure Assessment Methods

*0441. Kissell FN, Volkwein JC, Kohler JL [2002]. Historical perspective of personal dust sampling in coal mines. In: Proceedings of the North American/Ninth U.S. Mine Ventilation Symposium. Lisse, The Netherlands: Balkema, pp. 619-623.

NORA: Research Tools and Approaches: Exposure Assessment Methods

*0442. Kittusamy NK [2002]. Reducing risk of injury from jolting and jarring on mobile equipment in construction and agricultural industries. In: Proceedings Power Through Partnerships: 12th Annual Construction Safety and Health Conference. Chicago, IL: Construction Safety Council, pp. 293-295.

*0443. Knecht EA, Krieg EF Jr., Clark JC, Kesner JS [2002]. Urinary creatinine measurement using a Vitros 250 chemistry analyzer compared with the Jaffe method. In: Proceedings of the American Association for Clinical Chemistry 54th Annual Meeting. Orlando, FL: Clinical Chemistry 48(6):A55.

NORA: Research Tools and Approaches: Exposure Assessment Methods

*0444. Knudsen GA, Van Scott MR, Leonette JW, Fedan JS [2002]. Bioelectric response of guinea-pig (GP) tracheal epithelium (E) to hypotonic solution [Abstract]. FASEB J 16(5):A57.

*0445. Kowalski KM, Vaught C, Mallett LG, Brnich MJ Jr. [2002]. Issues for training an evolving emergency management workforce: a view from the U.S. mining community. In: Proceedings of The International Emergency Management Society (TIEMS) Ninth Annual Conference. Waterloo, Canada: pp. 430-438.

NORA: Research Tools and Approaches: Control Technology and Personal Protective Equipment

*0446. Kreiss K, Daroowalla F, Wang ML, Piacitelli C, Jones WG, Attfield MD [2002]. Flock workers' exposures and respiratory symptoms in five plants. In: Abstracts of the 12th Annual Congress of the European Respiratory Society. Stockholm, Sweden: European Respiratory Journal (Suppl) p. 2022.

NORA: Disease and Injury: Asthma and Chronic Obstructive Pulmonary Disease 


\section{Book Chapters/Proceedings/Abstracts/Technical Papers/Web}

*0447. Kreiss K, Gomaa A, Kullman G, Fedan K, Schleiff P, Simoes E, Enright P [2002]. Endemic bronchiolitis obliterans syndrome in microwave popcorn workers: a new occupational lung hazard. In: Abstracts of the 2002 International Conference of the American Thoracic Society. Atlanta, GA: p. A461.

NORA: Disease and Injury: Asthma and Chronic Obstructive Pulmonary Disease

*0448. Kullman G, Boylstein R, Piacitelli C, Jones W, Pendergrass S, Hubbs A, Kreiss K [2002]. Respiratory exposures from microwave popcorn packaging. In: Abstracts of the 2002 American Industrial Hygiene Conference and Exposition. San Diego, CA: p. 62.

NORA: Disease and Injury: Asthma and Chronic Obstructive Pulmonary Disease

*0449. Kyriazi N, Shubilla J [2002]. Respirator use and practices. Bureau of Labor Statistics, US Department of Labor News, 02-141.

*0450. Lawryk NJ [2002] Monitoring airborne metals on a near real-time basis: current and emerging NIOSH analytical methods for portable instruments. In: Proceedings of the U.S. Department of Energy Industrial Hygiene and Occupational Safety Special Interest Group Workshop. Baltimore, MD: Oak Ridge Institute for Science and Education. [http://www.orau.gov/ihos/oct30high.htm] NORA: Research Tools and Approaches: Exposure Assessment Methods

*0451. Lawryk NJ [2002] Portable instruments for measuring multiple airborne metals: future NIOSH analytical methods? In: Abstracts of the 2002 American Industrial Hygiene Conference and Exposition. San Diego, CA: FM 205.

NORA: Research Tools and Approaches: Exposure Assessment Methods

*0452. Lawryk NJ, Chen BT [2002]. Portable X-ray fluorescence spectrometry for measuring multiple airborne metals: a NIOSH screening method under development. In: Abstracts of the 2002 American Industrial Hygiene Conference and Exposition. San Diego, CA: PF 112. NORA: Research Tools and Approaches: Exposure Assessment Methods

*0453. Lawrence R, Coffey C, Campbell D, Jensen P, Myers W [2002]. Comparison of five methods for fit-testing N95 filtering-facepiece respirators alternate approaches. In: Abstracts of the 2002 American Industrial Hygiene Conference and Exposition. San Diego, CA: p. 98. NORA: Research Tools and Approaches: Control Technology and Personal Protective Equipment

*0454. Lee B, Gallagher S, Morteaga B, Hard D [2002]. Childhood agricultural injury prevention: progress report and updated national action plan from the 2001 summit. Marshfield, WI: Marshfield Clinic, April.

*0455. Lentz T, Hinze J [2002]. Surveys of occupational safety and health priorities in selected small and large construction firms. In: Proceedings of the 6th World Conference Injury Prevention and Control. Québec, Canada: Les Presses de I'Universite de Montréal, pp. 324-325. 


\section{Book Chapters/Proceedings/Abstracts/Technical Papers/Web}

*0456. Lindsley WG, Jensen N, Kommineni C [2002]. A mouse model for hand-arm vibration syndrome. In: Proceedings of the Second Joint EMBS/BMES Conference. Houston, TX: pp. 448-449. NORA: Disease and Injury: Musculoskeletal Disorders; Research Tools and Approaches: Exposure Assessment Methods

*0457. Lineberry GT, Wiehagen WJ, Scharf T, McCann M [2002]. Progress toward a multi-use educational intervention for reducing injury risk in the setup and use of extension ladders. In: Proceedings of the Sixth International Conference of the Scientific Committee on Education and Training in Occupational Health. Baltimore, MD: p. 64.

*0458. Little AR, O'Callaghan JP [2002]. The astrocyte response to neural injury: a review and reconsideration of key features. In: Site-selective neurotoxicity. Vol. 3. London: Taylor and Francis Group, pp. 233-265.

*0459. Liu L, Keane M, Cui M, Ensell M, Miller W, Kashon K, Ong T, Wallace W [2002]. In vitro genotoxicity of gasoline and diesel engine vehicle exhaust particulate and semi-volatile organic compound materials. In: Proceedings of the 8th Diesel Engine Emissions Reduction (DEER) Conference. San Diego, CA: [http://www.orau.gov/deer2002].

*0460. Luster MI [2002]. Preface to occupational immunology. Int Immunopharmacol 2(2-3):161-162.

*0461. Ma JYC, Frazer D, Barger MW, Rengasamy A, Hubbs A, Kane E, Battelli L, Tomblyn S, Stone S, Castranova V [2002]. Induction of CYP1A1 and NADPH quinone oxidoreductase (QR) with concomitant attenuation of CYP2B1 in the lung: effects of paving asphalt fume exposure [Abstract]. FASEB J 16(5):A962.

NORA: Work Environment and Workforce: Mixed Exposures

*0462. Ma Q [2002]. Impact of AH receptor degradation on gene transcription [Abstract]. The Toxicologist 66(1-S):5.

*0463. Ma Q, Kinneer KL, Burdette H, Denison M [2002]. Interaction of AH receptor with phenolic antioxidant signal transduction [Abstract]. The Toxicologist 66(1-S):258.

*0464. Mallett LG, Brnich MJ Jr., Vaught C [2002]. A training strategy that involves all employees in workplace risk assessment [Abstract]. In: Proceedings of the Sixth International Conference of the Scientific Committee on Education and Training in Occupational Health. Baltimore, MD: pp. 83-84.

NORA: Research Tools and Approaches: Control Technology and Personal Protective Equipment 


\section{Book Chapters/Proceedings/Abstracts/Technical Papers/Web}

*0465. Mark C [2002]. The introduction of roof bolting to U.S. underground coal mines (1948-1960): a cautionary tale. In: Proceedings of the 21st International Conference on Ground Control in Mining. Morgantown, WV: West Virginia University, pp. 150-160.

*0466. Mark C, Compton CS, Oyler DC, Dolinar DR [2002]. Anchorage pull testing for fully grouted roof bolts. In: Proceedings of the 21st International Conference on Ground Control in Mining. Morgantown, WV: West Virginia University, pp. 105-113.

*0467. Mark C, Karabin GJ Jr., Zelanko JC, Hoch MT, Chase FE [2002]. Evaluation of pillar recovery in southern West Virginia. In: Proceedings of the 21st International Conference on Ground Control in Mining. Morgantown, WV: West Virginia University, pp. 81-89.

NORA: Research Tools and Approaches: Risk Assessment Methods; Control Technology and Personal Protective Equipment

*0468. Mark C, Molinda GM, Barton TM [2002]. New developments with the coal mine roof rating. In: Proceedings of the 21st International Conference on Ground Control in Mining. Morgantown, WV: West Virginia University, pp. 294-301.

NORA: Research Tools and Approaches: Control Technology and Personal Protective Equipment

*0469. Martin S, Moyer E, Jensen P [2002]. Powered air-purifying particulate respirator integrity testing with a DOP challenge aerosol. In: Abstracts of the 2002 American Industrial Hygiene Conference and Exposition. San Diego, CA: p. 97.

NORA: Research Tools and Approaches: Control Technology and Personal Protective Equipment

*0470. Martin SB, Coffey CC, Lawrence RB, Calvert CA, Berardinelli SP, Jensen PA, Jones WG [2002]. Used ventilation filters: what is that smell? In: Abstracts of the 2002 American Industrial Hygiene Conference and Exposition. San Diego, CA: p. 24.

NORA: Research Tools and Approaches: Control Technology and Personal Protective Equipment

*0471. Martin SB, Wigal TG, Moyer ES [2002]. The effects of organic vapors on the efficiency of electrostatic respirator filter media. In: Abstracts of the 2002 American Industrial Hygiene Conference and Exposition. San Diego, CA: pp. 97-98.

NORA: Research Tools and Approaches: Control Technology and Personal Protective Equipment

*0472. McCawley M, Martin S, Moyer E, Berakis M, Hornsby-Myers J, Kent M [2002].

Development of a filter assembly to match the deposition of ultrafine aerosol in the lung: a pilot study with beryllium. In: Proceedings of an International Symposium on Inhaled Particles organized by the British Occupational Hygiene Society. Oxford, NY: Oxford University Press, pp. 215-218.

NORA: Research Tools and Approaches: Exposure Assessment Methods 


\section{Book Chapters/Proceedings/Abstracts/Technical Papers/Web}

*0473. McGinn S, Grenier M, Bugarski A, Schnakenberg GH Jr., Petrie D [2002]. Performance evaluation of diesel particulate filter technology in the underground environment. In:

Proceedings of the North American/Ninth U.S. Mine Ventilation Symposium. Lisse, The Netherlands: Balkema, pp. 433-440.

NORA: Research Tools and Approaches: Exposure Assessment Methods

*0474. McHugh E, Girard J [2002]. Evaluating techniques for monitoring rock falls and slope stability. In: Proceedings 21st International Conference on Ground Control in Mining. Morgantown, WV: West Virginia University, pp. 335-343.

*0475. McKenzie EA Jr., Etherton JR [2002]. NIOSH AutoROPS latch and release mechanism: second generation. In: Proceedings of American Society of Mechanical Engineers (ASME), Congress and Exposition. New Orleans, LA: IMECE Vol. 3, 32458 [CD-ROM]. NORA: Research Tools and Approaches: Control Technology and Personal Protective Equipment; Disease and Injury: Traumatic Injuries

*0476. McKinney W, Goldsmith T, Frazer D [2002]. Computer controlled ozone inhalation exposure system. In: Proceedings of the 21st Biomedical Engineering: Recent Developments. Washington, DC: Medical and Engineering Publishers, Inc., pp. 319-320.

*0477. McMillian MH, Cui M, Gautam M, Keane M, Ong T, Wallace W, Robey E [2002]. Mutagenic potential of particulate matter from diesel engine operation on Fischer-Tropsch Fuel as a function of engine operating conditions and particle size. In: Society of Automotive Engineers Technical Paper 2002-01-1699, pp. 1-18.

NORA: Work Environment and Workforce: Mixed Exposures; Research Tools and Approaches: Exposure Assessment Methods

*0478. Mercer RR, Wang L, Antonini J, Scabilloni JF, Castranova V [2002]. Role of apoptosis induction in development of lung injury from high burdens of titanium dioxide [Abstract]. The Toxicologist $66(1-\mathrm{S}): 118$.

*0479. Mercer RR, Wang L, Antonini JM, Scabilloni JF, Vallyathan V, Castranova V [2002]. Induction of apoptosis from instillation of agricultural dust [Abstract]. FASEB J 16(4):A962.

*0480. Metzler R [2002]. Establishment of the NIOSH National Personal Protective Technology Laboratory. In: Abstracts of the Eleventh Conference of the International Society for Respiratory Protection. Edinburgh, Scotland. [http://isrp.com.au]

*0481. Metzler R [2002]. Personal protective equipment: lessons learned from terrorist attacks [keynote address]. In: Abstracts of the Eleventh Conference of the International Society for Respiratory Protection. Edinburgh, Scotland. [http://isrp.com.au] 


\section{Book Chapters/Proceedings/Abstracts/Technical Papers/Web}

*0482. Metzler R, Sacks HK, Zhuang Z [2002]. Setting the respirator research agenda. In: Abstracts of the 2002 American Industrial Hygiene Association Conference and Exposition. San Diego, CA: Forum 235.

*0483. Metzler R, Zhuang Z, Berry Ann R [2002]. Setting the respirator research agenda. In: Abstracts of the Eleventh Conference of the International Society for Respiratory Protection. Edinburgh, Scotland. [http://isrp.com.au]

*0484. Michael K, Byrne DC [2002]. Current state of insert-type hearing protector fit-testing: follow-on measurements in the steel industry and fit-testing in a mobile environment. NHCA Spectrum 19(1):14-16.

NORA: Research Tools and Approaches: Control Technology and Personal Protective Equipment

*0485. Middendorf P, Syamlal G, Wang ML, Linch K, Wood J [2002]. Data mining: a technique for discovering novel exposure and health outcome relationships. In: Abstracts of the 2002 American Industrial Hygiene Conference and Exposition. San Diego, CA: p. 102. NORA: Work Environment and Workforce: Emerging Technologies

*0486. Miller DB, Benkovic SA, O'Callaghan JP [2002]. In vivo stress activates jak-stat in liver but not brain [Abstract]. The Toxicologist 66(1-S):218.

*0487. Moyer E, Commodore M, Hayes J, Fotta S [2002]. Filter efficiency of selected HVAC filters. In: Abstracts of the 2002 American Industrial Hygiene Conference and Exposition. San Diego, CA: p. 25.

NORA: Research Tools and Approaches: Control Technology and Personal Protective Equipment

*0488. Moyer E, Commodore M, Hayes J, Fotta S [2002]. Filter efficiency of selected HVAC filters. In: Proceedings of the 9th International Conference on Indoor Air Quality and Climate. Santa Cruz, CA: p. 76.

NORA: Research Tools and Approaches: Control Technology and Personal Protective Equipment

*0489. Murphy LR [2002]. Chapter 25: Stress management at work: secondary prevention of stress. In: The Handbook of Work and Health Psychology. 2nd ed. New York, NY: John Wiley \& Sons, Ltd., pp. 533-548.

NORA: Work Environment and Workforce: Organization of Work; Research Tools and Approaches: Intervention Effectiveness Research

*0490. Murphy LR [2002]. Job stress research at NIOSH: 1972-2002. In: Historical and Current Perspectives on Stress and Health. Vol. 2. New York: Elsevier Science Ltd., pp. 1-5.

NORA: Work Environment and Workforce: Organization of Work 


\section{Book Chapters/Proceedings/Abstracts/Technical Papers/Web}

*0491. NIOSH [2002]. National Institute for Occupational Safety and Health recommendations to the U.S. Department of Labor for changes to Hazardous Orders. Report to the U.S. Department of Labor, Employment Standards Administration, Wage and Hour Division. Morgantown, WV: Department of Health and Human Services, Public Health Service, Centers for Disease Control and Prevention, National Institute for Occupational Safety and Health, May 3, 2002.

NORA: Work Environment and Workforce: Special Populations at Risk

*0492. O'Callaghan JP, Miller DB [2002]. Neurotoxic effects of substituted amphetamines in rats and mice. In: Handbook of Neurotoxicology, Vol 2, Totowa, NJ: Humana Press Inc., pp. 269-301.

*0493. O'Callaghan JP, Sriram K, Luster MI, Felschow DM [2002]. Gene expression and cellsignaling events associated with toxicant-induced gliosis [Abstract]. The Toxicologist 66(1-S):270.

*0494. Orr TJ, Girard JM [2002]. Mine escapeway multiuser training with desktop virtual reality. In: Application of Computers and Operations Research in the Mineral Industry: Proceedings of the 30th International Symposium (APCOM 2002). Littleton, CO: Society of Mining, Metallurgy, and Exploration, Inc., pp. 577-784.

*0495. Pan CS [2002]. Drywall ergonomics. In: Proceedings of the 12th Annual Construction Safety and Health Conference and Exposition. Chicago, IL: Construction Safety Council, p. 333.

NORA: Disease and Injury: Traumatic Injuries; Research Tools and Approaches: Control Technology and Personal Protective Equipment

*0496. Pappas DM, Barton TM, Weiss ES [2002]. Developments in sealant support systems for ground control. In: Proceedings of the 21st International Conference on Ground Control in Mining. Morgantown, WV: West Virginia University, pp. 344-353.

*0497. Park J, Schleiff PL, Kreiss K, Attfield MD, Cox-Ganser J [2002]. Semi-quantitative mold exposure index predicts building related respiratory [Abstract]. In: Proceedings of the 9th International Conference on Indoor Air Quality and Climate. Santa Cruz, CA: pp. 365-370.

NORA: Work Environment and Workforce: Indoor Environment

*0498. Park J, Szponar B, Larsson L, Gold D, Milton M [2002]. Characterization of lipopolysaccharides in settled house dust. In: Abstracts of the 2002 American Industrial Hygiene Conference and Exposition. San Diego, CA: p. 93.

NORA: Work Environment and Workforce: Indoor Environment

*0499. Piacitelli C, Jones W [2002]. On the nature of aerosols generated during flock production and coating. In: Abstracts of the 2002 American Industrial Hygiene Conference and Exposition. San Diego, CA: p. 95.

NORA: Research Tools and Approaches: Exposure Assessment Methods 


\section{Book Chapters/Proceedings/Abstracts/Technical Papers/Web}

*0500. Poirier M, Weston A [2002]. DNA damage, DNA repair, and mutagenesis. In: Encyclopedia of Cancer. Vol 2, 2nd ed. San Diego, CA: Academic Press, pp. 79-87. NORA: Research Tools and Approaches: Cancer Research Methods

*0501. Qian Y, Zhang Z, Flynn DC, Shi X [2002]. Arsenite modulation of the integrity of actin filaments and the increase in cell motility may be mediated through CDC42. In: Abstracts of Papers, Experimental Biology 2002 Annual Meeting, New Orleans, LA. Federation of American Societies for Experimental Biology, Bethesda, MD: April 20-24.

NORA: Research Tools and Approaches: Cancer Research Methods

*0502. Ramani JM, Mutmansky JM, He H, Marple VA, Olson BA, Luna PC, Volkwein JC [2002]. Evaluation of the respirable dust dosimeter for real-time assessment of airborne respirable coal mine dust exposures. In: Proceedings of the North American/Ninth U.S. Mine Ventilation Symposium. Lisse, The Netherlands: Balkema, pp. 579-586.

NORA: Research Tools and Approaches: Exposure Assessment Methods

*0503. Ramani RV, Flick J, Radomsky M, Russell G, Calhoun RA, Haggerty JJ, Kowalski KM, Rethi LL, Stephenson CM, Scharf T [2002]. Hazard recognition: fall prevention in construction [Abstract]. In: Proceedings of the Sixth International Conference of the Scientific Committee on Education and Training in Occupational Health. Baltimore, MD: p. 62.

NORA: Research Tools and Approaches: Control Technology and Personal Protective Equipment

*0504. Rao C, Cox-Ganser J [2002]. Correlations of particles, allergens, fungi and bacteria in air and chair dust in a hospital setting. In: Proceedings of Indoor Air. Monterey, CA: The International Academy of Indoor Air Sciences, pp. 365-370.

NORA: Work Environment and Workforce: Indoor Environment

*0505. Rao C, Martin S, Cocalis J [2002]. Airborne microbial ecology in an underground coal mine. In: Abstracts of the 2002 American Industrial Hygiene Conference and Exposition. San Diego, CA: p. 94.

NORA: Work Environment and Workforce: Special Populations at Risk

*0506. Rengasamy A, Barger MW, Kane E, Ma JK, Castranova V, Ma JY [2002]. Diesel exhaust particle-induced alterations of pulmonary phase I and phase II enzyme systems [Abstract]. The Toxicologist 66(1-S):126.

NORA: Work Environment and Workforce: Mixed Exposures

*0507. Rice FL [2002]. Perspectives: Harris Martin interview with Faye Rice, MPH. ColumnsSilica 1(2):2-3, 6 .

*0508. Rice FL [2002]. Health effects of respirable crystalline silica: unanswered questions [Abstract]. Med Lav (Suppl) 93:S44. 


\section{Book Chapters/Proceedings/Abstracts/Technical Papers/Web}

*0509. Rice FL [2002]. National and international reviews of crystalline silica [Abstract]. Med Lav (Suppl) 93:S62-S63.

*0510. Robertson SB, Hinshaw GE [2002]. Roof screening: best practices and roof bolting machines. In: Proceedings of the 21st International Conference on Ground Control in Mining. Morgantown, WV: West Virginia University, pp. 189-194.

*0511. Rodriguez R, Rodriguez H, Lhamon M, Johnson J, Iverson S [2002]. Field-scale void detection in coal piles using resistivity imaging. In: NARMS-TAC: Mining and Tunneling Innovation and Opportunity. Toronto, Ontario, Canada: University of Toronto, pp. 415-419.

*0512. Sammarco JJ [2002]. A complexity assessment methodology for programmable electronic mining systems. In: Proceedings of the 20th International System Safety Conference. Unionville, VA: pp. 177-186.

NORA: Work Environment and Workforce: Emerging Technologies

*0513. Sammarco JJ [2002]. Addressing the safety of programmable electronic mining systems: lessons learned. In: Proceedings of the Institute of Electrical and Electronics Engineers, Inc. (IEEE) IAS 37th Annual Meeting. Pittsburgh, PA: pp. 692-698.

NORA: Work Environment and Workforce: Emerging Technologies

*0514. Sapko MJ, Rowland JH III, Mainiero RJ, Zlochower IA [2002]. Chemical and physical factors that influence $\mathrm{NO}_{2}$ production during blasting: exploratory study. In: Proceedings of the 28th Annual Conference on Explosives and Blasting Technique. Cleveland, OH: International Society of Explosives Engineers, pp. 317-329.

NORA: Research Tools and Approaches: Control Technology and Personal Protective Equipment

*0515. Sargent LM, Ensell MX, Senft JR, Lowry DT, Jefferson AM, Kashon ML, Tyson FL, Reynolds SH [2002]. Comparative cytogenetics of mouse and human lung adenocarcinoma. In: Program from 7th World Congress on Advances in Oncology and 5th International Symposium on Molecular Medicine. Crete, Greece: Hersonissos, Abstract 409.

*0516. Schleiff PL, Park JH, Attfield MD, Kreiss K [2002]. Building-related respiratory disease in college faculty and staff [Abstract]. Med Lav 93(5):377-378.

NORA: Work Environment and Workforce: Indoor Environment

*0517. Schubauer-Berigan M, Elliott LJ, Katz T, Neton J [2002]. Guidelines for determining the probability of causation under the U.S. Energy Employees Occupational Illness Compensation Program Act of 2000. In: Proceedings of the International Conference on Occupational Radiation Protection: Protecting Workers Against Exposure to Ionizing Radiation. International Atomic Energy Agency (IAEA). Geneva, Switzerland: CN-91, pp. 581-584. 


\section{Book Chapters/Proceedings/Abstracts/Technical Papers/Web}

*0518. Schuler C, Deubner D, McCawley M, Berakis M, Henneberger P, Kreiss K, Kent M [2002]. Job-related risk of beryllium disease at a beryllium copper alloy facility. In: Abstracts of the International Conference of the American Thoracic Society. Atlanta, GA: p. A49.

NORA: Research Tools and Approaches: Exposure Assessment Methods

*0519. Schulte PA, Ward E, Toraason M, Blair A, Brandt-Rauf P, Melnick R, Rothman N, Tennant R, Weston A, Meirer F, Bonassi S [2002]. Criteria for utilizing high output technologies for occupational cancer research and prevention [Abstract]. Cancer Epidemiol Biomarkers Prev $11: 1176 \mathrm{~s}$.

NORA: Research Tools and Approaches: Cancer Research Methods

*0520. Shulman SA, Mead KR, Mickelsen RL [2002]. Modeling performance of engineering controls when reductions are largest at the highest environmental concentrations of the hazardous contaminant. In: Proceedings of the American Statistical Association, Section on Physical and Engineering Sciences. Alexandria, VA: [CD-ROM].

*0521. Sieber WK, Williams LA, Catlett LR, Wilkins JR III [2002]. Agreement between selfreported use and observed presence of pesticides and its relationship to the odds ratio. In: Proceedings of the American Statistical Association. Alexandria, VA: [CD-ROM]. NORA: Research Tools and Approaches: Surveillance Research Methods

*0522. Simeonov P, Hsiao H, Dotson B, Ammons D [2002]. Comparing standing balance at real and virtual elevated environments. In: Proceedings of the 46th Human Factors and Ergonomics Society Annual Meeting. Baltimore, MD: pp. 2169-2173.

NORA: Disease and Injury: Traumatic Injuries

*0523. Singh H, Demchuk E, Hnizdo V, Sharp DS [2002]. Stochastic modeling of rotational degrees of freedom in molecules. In: Proceedings of the Hawaii International Conference on Statistics, Honolulu, HI: University of Hawaii-West Oahu [CD-ROM].

*0524. Snawder JE, Butler MA, Clark JC, Knecht EA, Krieg EF Jr. [2002]. Sensitive early indicators of hepatic and kidney damage in workers exposed to jet fuel (JP-8) [Abstract]. The Toxicologist 66(1-S):284.

NORA: Research Tools and Approaches: Exposure Assessment Methods

*0525. Stayner L, Toraason M, Hattis D [2002]. Of mice, men, and models: future research for improving risk assessment methods. Human Ecol Risk Assess 8(6):1195-1487.

NORA: Research Tools and Approaches: Risk Assessment Methods

*0526. Steenland K, Attfield M, Mannetje A [2002]. Pooled analyses of renal disease mortality and crystalline silica exposure in three cohorts. In: Proceedings of an International Symposium 


\section{Book Chapters/Proceedings/Abstracts/Technical Papers/Web}

on Inhaled Particles organized by the British Occupational Hygiene Society. Oxford, NY: Oxford University Press, pp. 4-9.

NORA: Research Tools and Approaches: Exposure Assessment Methods

*0527. Stemple KJ, Tift B, Reynolds JS, Weissman DN [2002]. Test performance of electronic recording peak flow meters [Abstract]. Am J Respir Crit Care Med 165(8):A497.

*0529. Stephenson M, Stephenson CM [2002]. Hearing protectors: only as good as the fit. Hearing conservation training program [CD-ROM]. NORA: Disease and Injury: Hearing Loss; Work Environment and Workforce: Special Populations at Risk; Research Tools and Approaches: Intervention Effectiveness Research

*0530. Stewart BM, Patton PW, Clark CC [2002]. Methods to minimize injuries in materialshandling and processes in underground mines. SME preprint 02-103. Society for Mining, Metallurgy, and Exploration, Inc. [CD-ROM].

*0531. Stone S, Goldsmith T, Afshari A, Frazer D [2002]. A system for asphalt fume generation. In: Proceedings of the 21st Biomedical Engineering: Recent Developments. Washington, DC: Medical and Engineering Publishers, Inc., pp. 321-322.

*0532. Swanson P [2002]. Feasibility of using laser-based vibration measurements to detect roof fall hazards in underground mines. In: Proceedings of the Fifth International Conference on Vibration Measurement by Laser Techniques: Advances and Applications. Bellingham, WA: International Society for Optical Engineering (SPIE), Vol. 4827, pp. 541-552.

*0533. Swanson P, Kenner B, Krahenbuhl T [2002]. Seismic event data acquisition and processing: distribution and coordination across PC based networks. In: Application of computers and operations research in the mineral industry: Proceedings of the 30th International Symposium (APCOM 2002). Littleton, CO: Society of Mining, Metallurgy, and Exploration, Inc., pp. 637-647.

*0534. Taylor CD, Chilton JE, Mal T [2002]. Evaluating performance characteristics of machinemounted methane monitors by measuring response time. In: Proceedings of the North American/ Ninth U.S. Mine Ventilation Symposium. Lisse, The Netherlands: Balkema, pp. 315-321. NORA: Research Tools and Approaches: Control Technology and Personal Protective Equipment

*0535. Taylor CD, Timko RJ, Thimons ED, Zimmer JA [2002]. Safety concerns associated with the use of electrically powered haulage to remove workers from mines during main fan stoppages. In: Proceedings of the North American/Ninth U.S. Mine Ventilation Symposium. Lisse, The Netherlands: Balkema, pp. 649-653. NORA: Research Tools and Approaches: Control Technology and Personal Protective Equipment 


\section{Book Chapters/Proceedings/Abstracts/Technical Papers/Web}

*0536. Taylor MD, Lewis AB, Roberts JR, Leonard SS, Shi X, Antonini JM [2002]. Effects of welding fumes on lung injury and inflammation: the possible role of free radical production [Abstract]. The Toxicologist 66(1-S):193.

NORA: Work Environment and Workforce: Mixed Exposures

*0537. Tesarik D, Johnson J, Zipf RK Jr., Lande K [2002]. Initial stability study of large openings for the National Underground Science Laboratory at the Homestake Mine, Lead, SD. In: NARMS TAC: Mining and Tunneling Innovation and Opportunity. Toronto, Ontario, Canada: University of Toronto, pp. 157-163.

*0538. Trevits MA, Monaghan WD, Mowrey GL, Sapko MJ, Thomas RA [2002]. Use of ground-penetrating radar and Schmidt Hammer tests to determine the structural integrity of a mine seal. In: Proceedings of the Symposium on the Application of Geophysics to Environmental and Engineering Problems (SAGEEP). Denver, CO: Environmental and Engineering Geophysical Society, Paper No. 12MMM5.

*0539. Trevits MA, Urosek JE [2002]. Technology for remote mine seal construction. SME preprint 02-185. Littleton, CO: Society for Mining, Metallurgy, and Exploration, Inc., pp. 1-4.

*0540. Trutt FC, Kohler JL, Sottile J [2002]. An experimental study of the relationship between bearing vibrations and deterioration of induction machine stator windings. In: Proceedings of the 26th National Technical Training Symposium of the Vibration Institute. Willowbrook, IL: pp. 135-141.

*0541. Turner N, Sinkule E, Hota S [2002]. Development of air-purifying respirator $\mathrm{CO}_{2}$ test using ABMS. In: Abstracts of the 2002 American Industrial Hygiene Association Conference and Exposition. San Diego, CA: p. 34.

NORA: Research Tools and Approaches: Control Technology and Personal Protective Equipment

*0542. Turner N, Sinkule E, Hota S [2002]. Performance of self-contained self-rescuers during a man test 4 protocol for the automated breathing and metabolic simulator. In: Abstracts of the 2002 American Industrial Hygiene Association Conference and Exposition. San Diego, CA: p. 47. NORA: Research Tools and Approaches: Control Technology and Personal Protective Equipment

*0543. Tyurina YY, Tyurin VA, Liu SX, Smith CA, Shvedova AA, Schor NF, Kagan VE [2002]. Phosphatidylserine peroxidation during apoptosis. In: Subcellular Biochemistry: Phospholipid Metabolism in Apoptosis. New York, NY: Kluwer Academic/Plenum Publishers, Vol 36. pp. 79-96.

*0544. Vallyathan V, Hnizdo E [2002]. Mechanisms of crystalline silica and coal-induced emphysema development [Abstract]. Med Lav (Suppl) 93:S66.

NORA: Work Environment and Workforce: Mixed Exposures 


\section{Book Chapters/Proceedings/Abstracts/Technical Papers/Web}

*0545. Vo E [2002]. Development of colorimetric indicators: a new technique to determine glutaraldehyde and alkaline glutaraldehyde contamination. In: Proceedings of the International Conference on Occupational and Environmental Exposures of Skin to Chemicals: Science and Policy. Washington, DC: National Institute for Occupational Safety and Health (NIOSH), p. 5. NORA: Disease and Injury: Allergic and Irritant Dermatitis; Research Tools and Approaches: Control Technology and Personal Protective Equipment

*0546. Vo E, Klingner T, Zhuang ZZ [2002]. Development of a glove end of service life indicator (ESLI) for weak organic and inorganic acids. In: Proceedings of the International Conference on Occupational and Environmental Exposures of Skin to Chemicals: Science and Policy. Washington, DC: National Institute of Occupational Safety and Health (NIOSH), p. 17. NORA: Disease and Injury: Allergic and Irritant Dermatitis; Research Tools and Approaches: Control Technology and Personal Protective Equipment

*0547. Volberg O, Ambrose DH [2002]. Motion editing and reuse techniques and their role in studying events between a machine and its operator. In: Proceedings of the Society of Computer Simulation International Advanced Simulation Technologies Conference. San Diego, CA: 34(4):181-186.

NORA: Disease and Injury: Low Back Disorders; Research Tools and Approaches: Control Technology and Personal Protective Equipment

*0548. Volkwein JC, Tuchman DP, Vinson RP [2002]. Performance of a prototype personal dust monitor for coal mine use. In: Proceedings of the North American/Ninth U.S. Mine Ventilation Symposium. Lisse, The Netherlands: Balkema, pp. 633-639.

NORA: Research Tools and Approaches: Exposure Assessment Methods

*0548a. Wallace WE, Chen J, Harrison J, Hnizdo V, Chen W, Nelson J, Chisholm W, Hnizdo E, Keane MJ, Miller WE [2002]. Respirable silica particle occlusion by alumino-silicate: surface properties of dusts with disease risk anomalies. [Abstract]. Med Lav (Suppl) 93:S24.

NORA: Work Environment and Workforce: Mixed Exposures; Research Tools and Approaches: Exposure Assessment Methods

*0548b. Wallace WE, Gupta NC, Hubbs AF, Mazza SM, Bishop HA, Keane MJ, Battelli LA, Ma JYC, Schleiff P [2002]. Positron emission tomographic (PET) imaging of silicosis in a rabbit model using 18F-fluorinated proline amino acid analog tracer. [Abstract]. Med Lav (Suppl) 93:S66-S67.

NORA: Research Tools and Approaches: Exposure Assessment Methods

*0549. Wang JJ, Lewis DM, Law B, Frazer DG, Stone S, Goldsmith T, Mosley A, Simpson J, Siegel PD [2002]. Biomarker characterization of asphalt fume exposure [Abstract]. The Toxicologist $66(1-\mathrm{S}): 284$.

NORA: Work Environment and Workforce: Mixed Exposures 


\section{Book Chapters/Proceedings/Abstracts/Technical Papers/Web}

*0550. Wang L, Medan D, Huang C, Shi X, Mercer RR, Millecchia L, Castranova V, Rojanasakul Y [2002]. Vanadium-induced pulmonary inflammation and apoptosis in mice [Abstract]. The Toxicologist 66(1-S):354.

NORA: Work Environment and Workforce: Mixed Exposures

*0551. Wang L, Scabilloni J, Rojanasakul Y, Antonini J, Zhang Z, Castranova V, Mercer RR [2002]. Role of lung surfactant in phagocytic clearance of apoptotic cells by macrophages during the development of pulmonary inflammation and fibrosis [Abstract]. FASEB J 16(4):A1151.

*0552. Wang M, Petsonk E, Castellan R, Wagner G [2002]. Film quality in chest x-ray screening for pneumoconiosis. In: Abstracts of the 2002 International Conference of the American Thoracic Society. Atlanta, GA: p. 528.

NORA: Research Tools and Approaches: Risk Assessment Methods

*0553. Wassell JT [2002]. Causal analysis of back belts to prevent low-back pain. In: Proceedings of the American Statistical Association, Section on Statistics in Epidemiology. Alexandria, VA: [CD-ROM].

NORA: Disease and Injury: Low Back Disorders; Research Tools and Approaches: Intervention Effectiveness Research

*0554. Wassell JT [2002]. Numerical methods of statistics [book review]. Technometrics 44(1):91-92.

*0555. Waters MA, Bloom TF, Grajewski B, Deddens J [2002]. Measurements of indoor air quality on commercial transport aircraft. In: Proceedings of the 9th International Conference on Indoor Air Quality and Climate. Santa Cruz, CA: pp. 782-787.

NORA: Work Environment and Workforce: Indoor Environment

*0556. White B [2002]. Shear mechanism for mining-induced fractures applied to rock mechanics of coal mines. In: Proceedings of the 21st International Conference on Ground Control in Mining. Morgantown, WV: West Virginia University, pp. 328-334.

*0557. White BG, Williams TJ, Whyatt JK [2002]. Mechanics of a large, strain-type rock burst and design for prevention. In: NARMS-TAC 2002: Mining and Tunneling Innovation and Opportunity. Toronto, Ontario, Canada: University of Toronto, Vol. 2. pp. 1095-1100.

*0558. Whyatt J, Blake W, Williams TJ, White B [2002]. 60 years of rockbursting in the Coeur d'Alene District of northern Idaho, USA: lessons learned and remaining issues. SME preprint 02-164. Society for Mining, Metallurgy, and Exploration, Inc. [CD ROM].

*0559. Wiehagen WJ, Ramani RV, Calhoun RA, Flick J, Radomsky M, Russell G, Haggerty JJ, Kowalski KM, Rethi LL, Stephenson CM, Scharf T [2002]. Ladder simulation exercise for 


\section{Book Chapters/Proceedings/Abstracts/Technical Papers/Web}

construction, mining, and other industries. In: Proceedings of the Sixth International Conference of the Scientific Committee on Education and Training in Occupational Health, Baltimore, MD: p. 63.

*0559a. Williams AA, Parashar UD, Stoica A, Ridzon R, Kirschke DL, Meyer RF, McClellan J, Fischer M, Nelson R, Cartter M, Hadler JL, Jernigan JA, Mast EE, Swerdlow DL. Connecticut Anthrax Investigation Team [2002]. Bioterrorism-related anthrax surveillance, Connecticut, September-December, 2001. Emerg Infect Dis [serial online]. Available from: URL: http://www.cdc.gov/ncidod/EID/vol8no10/02-0399.htm

*0560. Witte K, Vaught C, Stephenson M [2002]. A project to evaluate the role positive and negative emotion plays in promoting hearing conservation behaviors among coal miners. In: Proceedings of the Sixth International Conference of the Scientific Committee on Education and Training in Occupational Health. Baltimore, MD: pp. 81-82.

NORA: Research Tools and Approaches: Control Technology and Personal Protective Equipment

*0561. Wu DXY, Johnston RA, Van Scott MR, Fedan JS [2002]. Bioelectric responses of guinea-pig tracheal epithelium to hyperosmolar and isosmolar challenges [Abstract]. Am J Respir Crit Care Med 165(8):A66.

*0562. Wu JZ, Dong RG, Schopper AW, Smutz WP [2002]. Modeling of biomechanics of tactile sensation on fingertips. In: Proceedings of the IV World Congress Biomechanics. Calgary, Canada: August 4-9. [CD-ROM].

NORA: Disease and Injury: Musculoskeletal Disorders; Research Tools and Approaches: Control Technology and Personal Protective Equipment

*0563. Wu JZ, Dong RG, Schopper AW, Smutz WP [2002]. Modeling of force response of fingertips in keyboard strikes. In: Proceedings of the IV World Congress Biomechanics. Calgary, Canada: August 4-9. [CD-ROM].

NORA: Disease and Injury: Musculoskeletal Disorders; Research Tools and Approaches: Control Technology and Personal Protective Equipment

*0564. Wu JZ, Dong RG, Smutz WP [2002]. Characterization of nonlinear and time-dependent behavior of skin under compression. In: Proceedings of the 21st Biomedical Engineering: Recent Developments. Washington, DC: Medical and Engineering Publishers, Inc., pp. 187-188. NORA: Disease and Injury: Musculoskeletal Disorders; Research Tools and Approaches: Control Technology and Personal Protective Equipment

*0564a. Wu ZX, Satterfield BE, Fedan JS, Dey RD [2002]. Ozone-enhanced airway hyperresponsiveness involves intrinsic airway neurons in ferret trachea [Abstract]. Am J Respir Crit Care Med 165:A718. 


\section{Book Chapters/Proceedings/Abstracts/Technical Papers/Web}

*0565. Yin XJ, Schafer R, Antonini JM, Barger MW, Dong C-Z, Roberts JR, de la Rosa P, Ma JYC, Ma JKH [2002]. Alternation of innate and cell-mediated immunity to listeria monocytogenes by short-term exposure to diesel exhaust particles [Abstract]. FASEB J 16(5):A962.

NORA: Work Environment and Workforce: Mixed Exposures

*0566. Young S, Robinson VA, Barger M, Frazer DG, Castranova V [2002]. Particulate 1 $\rightarrow 3-\beta$ glucan is the more potent form for inducing pulmonary inflammation in rats [Abstract]. The Toxicologist 66(1-S):354.

NORA: Work Environment and Workforce: Mixed Exposures

*0567. Zahl E, Dunford J, Larson M, Brady T, Chen J [2002]. Stress measurements for safety decisions in longwall coal. In: Proceedings of the 21st International Conference on Ground Control in Mining. Morgantown, WV: West Virginia University, pp. 45-52.

*0568. Zhao H, Yin X, Frazer D, Barger M, Tomblyn S, Stone S, Ma J, Castranova V, Ma J [2002]. Effects of paving asphalt fume exposure on genotoxic and mutagenic activities in the lung [Abstract]. FASEB J 16(5):A962.

NORA: Work Environment and Workforce: Mixed Exposures

*0569. Zhuang Z [2002]. Correlation between quantitative fit factors and protection factors measured under actual workplace environments at a steel foundry. In: Abstracts of the Eleventh Conference of the International Society for Respiratory Protection. Edinburgh, Scotland: Abstract 16. [http://isrp.com.au]

NORA: Research Tools and Approaches: Control Technology and Personal Protective Equipment

*0570. Zhuang Z, BerryAnn R [2002]. Recent NIOSH research on fit-test. In: Abstracts of the Eleventh Conference of the International Society for Respiratory Protection. Edinburgh, Scotland: Abstract 18 [http://www.isrp.com.au]

NORA: Research Tools and Approaches: Control Technology and Personal Protective Equipment

*0571. Zhuang Z, Guan J, Hsiao H [2002]. Recapturing the sizing issues of respirator fit-test panels for emergency response. Book of Abstracts of the Eleventh Conference of the International Society for Respiratory Protection. Edinburgh, Scotland: Abstract 17 [http://www.isrp.com.au]

NORA: Research Tools and Approaches: Control Technology and Personal Protective Equipment

*0572. Zhuang Z, Jensen PA, Berardinelli S, Coffey C, Hewett P, Viscusi D [2002]. Characterization of foundry particle sizes and selection of agents for WPF measurement. In: Abstracts of the 2002 American Industrial Hygiene Conference and Exposition. San Diego, CA: p. 98. NORA: Research Tools and Approaches: Exposure Assessment Methods 
*0573. Zhuang Z, Odencrantz J, Jensen PA, Coffey CC, Guan J, Hsiao H [2002]. Two new approaches for developing respirator fit-test panels representative of US workers. In: Abstracts of the 2002 American Industrial Hygiene Conference and Exposition. San Diego, CA: p. 48. NORA: Research Tools and Approaches: Control Technology and Personal Protective Equipment

*0574. Zipf RK Jr. [2002]. Mathematics, statistics, and probability, Chapter 5. In: SME Mining Reference Handbook. Littleton, CO: Society for Mining, Metallurgy, and Exploration, pp. $103-126$.

*0575. Zipf RK Jr. [2002]. Physical science and engineering, Chapter 4. In: SME Mining Reference Handbook. Littleton, CO: Society for Mining, Metallurgy, and Exploration, pp. 69-102.

*0576. Zipf RK Jr., Tesarik D, Johnson J [2002]. Empirical and analytical design of large openings at a proposed National Underground Science Laboratory. Proceedings of the 21st International Conference on Ground Control in Mining. Morgantown, WV: West Virginia University, pp. 318-327. 


\section{HAZARD EVALUATION AND TECHNICAL ASSISTANCE REPORTS}

*0577. NIOSH [2002]. Hazard evaluation and technical assistance report: Crumb-rubber modified asphalt paving: occupational exposures and acute health effects. Cincinnati, $\mathrm{OH}$ : Department of Health and Human Services, Public Health Service, Centers for Disease Control and Prevention, National Institute for Occupational Safety and Health, NIOSH HETA Report No. 2001-0536-2864.

*0578. NIOSH [2002]. Hazard evaluation and technical assistance report: 26 Federal Plaza, New York, NY. Cincinnati, OH: Department of Health and Human Services, Public Health Service, Centers for Disease Control and Prevention, National Institute for Occupational Safety and Health, NIOSH HETA Report No. 2002-0038-2870.

*0579. NIOSH [2002]. Hazard evaluation and technical assistance report: City of Cincinnati Sewers, Water Works, and Public Services, Cincinnati, OH. Cincinnati, OH: Department of Health and Human Services, Public Health Service, Centers for Disease Control and Prevention, National Institute for Occupational Safety and Health, NIOSH HETA Report No. 2001-0073-2869.

*0580. NIOSH [2002]. Hazard evaluation and technical assistance report: Custom Products, Inc., Mooresville, NC. Cincinnati, OH: Department of Health and Human Services, Public Health Service, Centers for Disease Control and Prevention, National Institute for Occupational Safety and Health, NIOSH HETA Report No. 98-0153-2883.

*0581. NIOSH [2002]. Hazard evaluation and technical assistance report: Glass Masters Neon, Savannah, GA. Cincinnati, OH: Department of Health and Human Services, Public Health Service, Centers for Disease Control and Prevention, National Institute for Occupational Safety and Health, NIOSH HETA Report No. 2001-0081-2877.

*0582. NIOSH [2002]. Hazard evaluation and technical assistance report: Human Performance International, Inc., Charlotte, NC. Cincinnati, OH: Department of Health and Human Services, Public Health Service, Centers for Disease Control and Prevention, National Institute for Occupational Safety and Health, NIOSH HETA Report No. 2000-0110-2849.

*0583. NIOSH [2002]. Hazard evaluation and technical assistance report: Immigration and Naturalization Service, San Diego, CA. Cincinnati, OH: Department of Health and Human Services, Public Health Service, Centers for Disease Control and Prevention, National Institute for Occupational Safety and Health, NIOSH HETA Report No. 2001-0483-2884. 


\section{Hazard Evaluation and Technical Assistance Reports}

*0584. NIOSH [2002]. Hazard evaluation and technical assistance report: Indiana Transmission Plant, Kokomo, IN. Cincinnati, OH: Department of Health and Human Services, Public Health Service, Centers for Disease Control and Prevention, National Institute for Occupational Safety and Health, NIOSH HETA Report No. 2002-0155-2886.

*0585. NIOSH [2002]. Hazard evaluation and technical assistance report: Jergens Road Adult Services Center, Dayton, OH. Cincinnati, OH: Department of Health and Human Services, Public Health Service, Centers for Disease Control and Prevention, National Institute for Occupational Safety and Health, NIOSH HETA Report No. 2002-0218-2881.

*0586. NIOSH [2002]. Hazard evaluation and technical assistance report: Lead Safe Services, Inc., Neenah, WI. Cincinnati, OH: Department of Health and Human Services, Public Health Service, Centers for Disease Control and Prevention, National Institute for Occupational Safety and Health, NIOSH HETA Report No. 99-0305-2878.

*0587. NIOSH [2002]. Hazard evaluation and technical assistance report: Mueller Company, Chattanooga, TN. Cincinnati, OH: Department of Health and Human Services, Public Health Service, Centers for Disease Control and Prevention, National Institute for Occupational Safety and Health, NIOSH HETA Report No. 98-0237-2872.

*0588. NIOSH [2002]. Hazard evaluation and technical assistance report: STN Cushion Company, Thomasville, NC. Cincinnati, OH: Department of Health and Human Services, Public Health Service, Centers for Disease Control and Prevention, National Institute for Occupational Safety and Health, NIOSH HETA Report No. 2000-0410-2891.

*0589. NIOSH [2002]. Hazard evaluation and technical assistance report: Superior Label Systems, Mason, OH. Cincinnati, OH: Department of Health and Human Services, Public Health Service, Centers for Disease Control and Prevention, National Institute for Occupational Safety and Health, NIOSH HETA Report No. 2001-0144-2867.

*0590. NIOSH [2002]. Hazard evaluation and technical assistance report: TRW Automotive, Mt. Vernon, OH. Cincinnati, OH: Department of Health and Human Services, Public Health Service, Centers for Disease Control and Prevention, National Institute for Occupational Safety and Health, NIOSH HETA Report No. 2001-0303-2893.

*0591. NIOSH [2002]. Hazard evaluation and technical assistance report: Tenneco Automotive, Milan, OH. Cincinnati, OH: Department of Health and Human Services, Public Health Service, Centers for Disease Control and Prevention, National Institute for Occupational Safety and Health, NIOSH HETA Report No. 2000-0124-2875.

*0592. NIOSH [2002]. Hazard evaluation and technical assistance report: Thomas Steel Strip Corporation, Warren, OH. Cincinnati, OH: Department of Health and Human Services, Public 


\section{Hazard Evaluation and Technical Assistance Reports}

Health Service, Centers for Disease Control and Prevention, National Institute for Occupational Safety and Health, NIOSH HETA Report No. 99-0343-2882.

*0593. NIOSH [2002]. Hazard evaluation and technical assistance report: Department of the Interior, Grand Canyon National Park, Grand Canyon, AZ. Cincinnati, OH: Department of Health and Human Services, Public Health Service, Centers for Disease Control and Prevention, National Institute for Occupational Safety and Health, NIOSH HETA Report No. 99-0321-2873.

*0594. NIOSH [2002]. Hazard evaluation and technical assistance report: United States Air Force, Davis-Monthan Air Force Base, Tucson, AZ. Cincinnati, OH: Department of Health and Human Services, Public Health Service, Centers for Disease Control and Prevention, National Institute for Occupational Safety and Health, NIOSH HETA Report No. 2000-0066-2892.

*0595. NIOSH [2002]. Hazard evaluation and technical assistance report: United States Air Force, Seymour Johnson Air Force Base, Goldsboro, NC. Cincinnati, OH: Department of Health and Human Services, Public Health Service, Centers for Disease Control and Prevention, National Institute for Occupational Safety and Health, NIOSH HETA Report No. 2000-0061-2885.

*0596. NIOSH [2002]. Hazard evaluation and technical assistance report: United States Senate and House of Representatives, Washington, DC. Cincinnati, OH: Department of Health and Human Services, Public Health Service, Centers for Disease Control and Prevention, National Institute for Occupational Safety and Health, NIOSH HETA Report No. 2002-0136-2880.

*0597. NIOSH [2002]. Hazard evaluation and technical assistance report: Benefis Healthcare, Great Falls, Montana. Cincinnati, OH: Department of Health and Human Services, Public Health Service, Centers for Disease Control and Prevention, National Institute for Occupational Safety and Health, NIOSH HETA Report No. 2000-0255-2868.

NORA: Work Environment and Workforce: Indoor Environment

*0598. NIOSH [2002]. Hazard evaluation and technical assistance report: Nassau Community College, Garden City, New York. Cincinnati, OH: Department of Health and Human Services, Public Health Service, Centers for Disease Control and Prevention, National Institute for Occupational Safety and Health, NIOSH HETA Report No. 2000-0168-2871.

NORA: Work Environment and Workforce: Indoor Environment 


\section{NIOSH NUMBERED PUBLICATIONS}

*0599. NIOSH [2002]. Violence: occupational hazards in hospitals. Cincinnati, OH: Department of Health and Human Services, Public Health Service, Centers for Disease Control and Prevention, National Institute for Occupational Safety and Health, DHHS (NIOSH) Publication No. 2002-101.

*0600. NIOSH [2002]. The faces of mining: a tribute to miners and mine safety, Spokane Research Laboratory 2002 calendar. Spokane, WA: Department of Health and Human Services, Public Health Service, Centers for Disease Control and Prevention, National Institute for Occupational Safety and Health, DHHS (NIOSH) Publication No. 2002-103.

*0601. NIOSH [2002]. Certified equipment list as of September 30, 2001. Morgantown, WV: Department of Health and Human Services, Public Health Service, Centers for Disease Control and Prevention, National Institute for Occupational Safety and Health, DHHS (NIOSH) Publication No. 2002-104.

*0602. NIOSH [2002]. Silicosis in sandblasters: a case study adapted for use in U.S. high schools. Cincinnati, OH: Department of Health and Human Services, Public Health Service, Centers for Disease Control and Prevention, National Institute for Occupational Safety and Health, DHHS (NIOSH) Publication No. 2002-105.

*0603. NIOSH [2002]. NIOSH bibliography of communication and research products. Cincinnati, OH: Department of Health and Human Services, Public Health Service, Centers for Disease Control and Prevention, National Institute for Occupational Safety and Health, DHHS (NIOSH) Publication No. 2002-106.

*0604. NIOSH [2002]. Traumatic incident stress: information for emergency response workers. Cincinnati, OH: Department of Health and Human Services, Public Health Service, Centers for Disease Control and Prevention, National Institute for Occupational Safety and Health, DHHS (NIOSH) Publication No. 2002-107.

*0605. NIOSH [2002]. Interim recommendations for firefighters and other first responders for the selection and use of protective clothing and respirators against biological agents. Cincinnati, $\mathrm{OH}$ : Department of Health and Human Services, Public Health Service, Centers for Disease Control and Prevention, National Institute for Occupational Safety and Health, DHHS (NIOSH) Publication No. 2002-109. 
*0606. NIOSH [2002]. HID 15. Fire fighters exposed to electrical hazards during wildland fire operations. Cincinnati, OH: Department of Health and Human Services, Public Health Service, Centers for Disease Control and Prevention, National Institute for Occupational Safety and Health, DHHS (NIOSH) Publication No. 2002-112.

*0607. NIOSH [2002]. Protecting workers' families: a research agenda. Report of the workers' family protection task force. Cincinnati, OH: Department of Health and Human Services, Public Health Service, Centers for Disease Control and Prevention, National Institute for Occupational Safety and Health, DHHS (NIOSH) Publication No. 2002-113.

*0608. NIOSH [2002]. Respirators: your TB defense and TB respiratory protection — administrators review, hosted by Loretta Swit [DVD]. Cincinnati, OH: Department of Health and Human Services, Public Health Service, Centers for Disease Control and Prevention, National Institute for Occupational Safety and Health, DHHS (NIOSH) Publication No. 2002-114D.

*0609. NIOSH [2002]. Surveillance and prevention of occupational injuries in Alaska. A decade of progress, 1990-1999. Cincinnati, OH: Department of Health and Human Services, Public Health Service, Centers for Disease Control and Prevention, National Institute for Occupational Safety and Health, DHHS (NIOSH) Publication No. 2002-115.

*0610. NIOSH [2002]. The changing organization of work safety and health of working people: knowledge gaps and research directions. Cincinnati, OH: Department of Health and Human Services, Public Health Service, Centers for Disease Control and Prevention, National Institute for Occupational Safety and Health, DHHS (NIOSH) Publication No. 2002-116.

NORA: Work Environment and Workforce: Organization of Work

*0610a. NIOSH [2002]. Worker health chartbook, 2000: fatal injury. Washington, DC: Department of Health and Human Services, Public Health Service, Centers for Disease Control and Prevention, National Institute for Occupational Safety and Health, DHHS (NIOSH) Publication No. 2002-117.

*0611. [NIOSH [2002]. Worker health chartbook, 2000: fatal illness. Washington, DC: Department of Health and Human Services, Public Health Service, Centers for Disease Control and Prevention, National Institute for Occupational Safety and Health, DHHS (NIOSH) Publication No. 2002-118.

*0612. NIOSH [2002]. Worker health chartbook, 2000: nonfatal injury. Washington, DC: Department of Health and Human Services, Public Health Service, Centers for Disease Control and Prevention, National Institute for Occupational Safety and Health, DHHS (NIOSH) Publication No. 2002-119.

*0613. NIOSH [2002]. Worker health chartbook, 2000: nonfatal illness. Washington, DC: Department of Health and Human Services, Public Health Service, Centers for Disease Control 
and Prevention, National Institute for Occupational Safety and Health, DHHS (NIOSH) Publication No. 2002-120.

*0614. NIOSH [2002]. Worker health chartbook, 2000: focus on mining. Washington, DC: Department of Health and Human Services, Public Health Service, Centers for Disease Control and Prevention, National Institute for Occupational Safety and Health, DHHS (NIOSH) Publication No. 2002-121.

*0615. NIOSH [2002]. Coal worker's X-ray surveillance program: frequently asked questions and resource list. Morgantown, WV: Department of Health and Human Services, Public Health Service, Centers for Disease Control and Prevention, National Institute for Occupational Safety and Health, DHHS (NIOSH) Publication No. 2002-122.

NORA: Research Tools and Approaches: Surveillance Research Methods

*0616. NIOSH [2002]. Electrical safety: safety and health for electrical trades student manual. Cincinnati, OH: Department of Health and Human Services, Public Health Service, Centers for Disease Control and Prevention, National Institute for Occupational Safety and Health, DHHS (NIOSH) Publication No. 2002-123.

NORA: Work Environment and Workforce: Special Populations at Risk; Research Tools and Approaches: Intervention Effectiveness Research

*0617. NIOSH [2002]. Exposure assessment methods research needs and priorities. Cincinnati, $\mathrm{OH}$ : Department of Health and Human Services, Public Health Service, Centers for Disease Control and Prevention, National Institute for Occupational Safety and Health, DHHS (NIOSH) Publication No. 2002-126.

NORA: Research Tools and Approaches: Exposure Assessment Methods

*0618. NIOSH [2002]. Self-contained self-rescuer field evaluation. Seventh-phase results— NIOSH Report of Investigation (RI) 9656. Pittsburgh, PA: Department of Health and Human Services, Public Health Service, Centers for Disease Control and Prevention, National Institute for Occupational Safety and Health, DHHS (NIOSH) Publication No. 2002-127. NORA: Research Tools and Approaches: Control Technology and Personal Protective Equipment

*0619. NIOSH [2002]. NIOSH evaluates worker exposures at a popcorn plant in Missouri. Cincinnati, OH: Department of Health and Human Services, Public Health Service, Centers for Disease Control and Prevention, National Institute for Occupational Safety and Health, DHHS (NIOSH) Publication No. 2002-128.

NORA: Disease and Injury: Asthma and Chronic Obstructive Pulmonary Disease

*0620. NIOSH [2002]. NIOSH hazard review: health effects of occupational exposure to respirable crystalline silica. Cincinnati, OH: Department of Health and Human Services, Public 


\section{NIOSH Numbered Publications}

Health Service, Centers for Disease Control and Prevention, National Institute for Occupational Safety and Health, DHHS (NIOSH) Publication No. 2002-129.

*0621. NIOSH [2002]. Zen and the art of bolting [VHS]. Spokane, WA: Department of Health and Human Services, Public Health Service, Centers for Disease Control and Prevention, National Institute for Occupational Safety and Health, DHHS (NIOSH) Publication No. 2002-131.

*0622. NIOSH [2002]. Programmable electronic mining systems: best practice recommendations (in nine parts) Part 4: 3.0 Safety file-NIOSH Information Circular (IC) 9461. Pittsburgh, PA: Department of Health and Human Services, Public Health Service, Centers for Disease Control and Prevention, National Institute for Occupational Safety and Health, DHHS (NIOSH) Publication No. 2002-134.

*0622a. NIOSH [2002] Recommendations for testing radar-based collision warning systems on heavy equipment-NIOSH Report of Investigations (RI) 9657. Pittsburgh, PA: Department of Health and Human Services, Public Health Service, Centers for Disease Control and Prevention, National Institute for Occupational Safety and Health, DHHS (NIOSH) Publication No. 2002-135.

*0623. NIOSH [2002]. Fire fighter fatality/injury reports and other related publications [CDROM]. Morgantown, WV: Department of Health and Human Services, Public Health Service, Centers for Disease Control and Prevention, National Institute for Occupational Safety and Health, NIOSH Publication No. 2002-136.

*0624. NIOSH [2002]. Office of compensation analysis and support (OCAS) [brochure]. Cincinnati, OH: Department of Health and Human Services, Public Health Service, Centers for Disease Control and Prevention, National Institute for Occupational Safety and Health, DHHS (NIOSH) Publication No. 2002-137.

*0624a. NIOSH [2002]. What a claimant should know about radiation dose reconstruction [fact sheet]. Cincinnati, OH: Department of Health and Human Services, Public Health Service, Centers for Disease Control and Prevention, National Institute for Occupational Safety and Health, DHHS (NIOSH) Publication No. 2002-138.

*0625. NIOSH [2002]. Guidance for protecting building environments from airborne chemical, biological, or radiological attacks. Cincinnati, OH: Department of Health and Human Services, Public Health Service, Centers for Disease Control and Prevention, National Institute for Occupational Safety and Health, DHHS (NIOSH) Publication No. 2002-139.

*0626. NIOSH [2002]. NIOSH pocket guide to chemical hazards and other databases [CD-ROM]. Cincinnati, OH: Department of Health and Human Services, Public Health Service, Centers for 
Disease Control and Prevention, National Institute for Occupational Safety and Health, DHHS (NIOSH) Publication No. 2002-140.

*0626a. NIOSH [2002] Drill monitor with strata strength classification in near-real timeNIOSH Report of Investigations (RI) 9658. Pittsburgh, PA: Department of Health and Human Services, Public Health Service, Centers for Disease Control and Prevention, National Institute for Occupational Safety and Health, DHHS (NIOSH) Publication No. 2002-141.

*0627. NIOSH [2002]. Protecting workers from anthrax infection. Cincinnati, OH: Department of Health and Human Services, Public Health Service, Centers for Disease Control and Prevention, National Institute for Occupational Safety and Health, DHHS (NIOSH) Publication No. 2002-142.

*0627a. NIOSH [2002]. NIOSH fact sheet: protecting workers at the World Trade Center site - response from the National Institute for Occupational Safety and Health. Cincinnati, OH: Department of Health and Human Services, Public Health Service, Centers for Disease Control and Prevention, National Institute for Occupational Safety and Health, DHHS (NIOSH) Publication No. 2002-143.

*0628. NIOSH [2002]. Certified equipment list as of March 31, 2002. Morgantown, WV: Department of Health and Human Services, Public Health Service, Centers for Disease Control and Prevention, National Institute for Occupational Safety and Health, DHHS (NIOSH) Publication No. 2002-144.

*0629. NIOSH [2002]. Mining facts for 2000 [fact sheet]. Pittsburgh, PA: Department of Health and Human Services, Public Health Service, Centers for Disease Control and Prevention, National Institute for Occupational Safety and Health, DHHS (NIOSH) Publication No. 2002-145.

*0630. NIOSH [2002]. Work, smoking, and health: a NIOSH scientific workshop. Washington, DC: Department of Health and Human Services, Public Health Service, Centers for Disease Control and Prevention, National Institute for Occupational Safety and Health, DHHS (NIOSH) Publication No. 2002-148.

NORA: Disease and Injury: Asthma and Chronic Obstructive Pulmonary Disease

*0631. NIOSH [2002]. Guidance for controlling potential risks to workers exposed to Class B biosolids. Morgantown, WV: Department of Health and Human Services, Public Health Service, Centers for Disease Control and Prevention, National Institute for Occupational Safety and Health, DHHS (NIOSH) Publication No. 2002-149.

NORA: Research Tools and Approaches: Control Technology and Personal Protective Equipment

*0632. NIOSH [2002]. Reproductive health: developing partnerships in the study of reproductive hazards in the workplace. Cincinnati, OH: Department of Health and Human Services, Public 
Health Service, Centers for Disease Control and Prevention, National Institute for Occupational Safety and Health, DHHS (NIOSH) Publication No. 2002-152.

NORA: Disease and Injury: Fertility and Pregnancy Abnormalities

*0633. NIOSH [2002]. Review of technology available to the underground mining industry for control of diesel emissions-NIOSH Information Circular (IC) 9462. Pittsburgh, PA:

Department of Health and Human Services, Public Health Service, Centers for Disease Control and Prevention, National Institute for Occupational Safety and Health, DHHS (NIOSH) Publication No. 2002-154.

NORA: Research Tools and Approaches: Control Technology and Personal Protective Equipment; Exposure Assessment Methods

*0634. NIOSH [2002]. Strategies for improving miners' training-NIOSH Information Circular (IC) 9463. Pittsburgh, PA: Department of Health and Human Services, Public Health Service, Centers for Disease Control and Prevention, National Institute for Occupational Safety and Health, DHHS (NIOSH) Publication No. 2002-156.

*0635. NIOSH [2002]. The NIOSH fire fighter fatality investigation and prevention program [brochure]. Morgantown, WV: Department of Health and Human Services, Public Health Service, Centers for Disease Control and Prevention, National Institute for Occupational Safety and Health, DHHS (NIOSH) Publication No. 2002-158.

*0636. NIOSH [2002]. Safety and health resource guide for small businesses. Cincinnati, OH: Department of Health and Human Services, Public Health Service, Centers for Disease Control and Prevention, National Institute for Occupational Safety and Health, DHHS (NIOSH) Publication No. 2003-100.

*0637. NIOSH [2002]. Proceedings of the international fishing industry safety and health conference (October 23-25, 2000-Woods Hole, MA). Morgantown, WV: Department of Health and Human Services, Public Health Service, Centers for Disease Control and Prevention, National Institute for Occupational Safety and Health, DHHS (NIOSH) Publication No. 2003-102.

*0640. NIOSH [2002]. Working with stress: a NIOSH TV production (DVD). Cincinnati, OH: Department of Health and Human Services, Public Health Service, Centers for Disease Control and Prevention, National Institute for Occupational Safety and Health, DHHS (NIOSH) Publication No. 2003-114D.

*0641. NIOSH [2002]. Working with stress: a NIOSH TV production (VHS). Cincinnati, OH: Department of Health and Human Services, Public Health Service, Centers for Disease Control and Prevention, National Institute for Occupational Safety and Health, DHHS (NIOSH) Publication No. 2003-114V. 
*0641a. NIOSH [2000]. Programa de evaluación de los peligros para la salud. Cincinnati, OH: Departamento de Salud y Servicios Humanos, Centros para el Control y la Prevención de Enfermedades, Instituto Nacional de Salud y Seguridad Ocupacional, DHHS (NIOSH) Número de Publicación 2000-132(Sp2002). Traducción en español: 2002.

*0642. NIOSH [2000]. Programa de evaluación de los peligros para la salud. Cincinnati, OH: Departamento de Salud y Servicios Humanos, Centros para el Control y la Prevención de Enfermedades, Instituto Nacional de Salud y Seguridad Ocupacional, DHHS (NIOSH) Número de Publicación 2000-133(Sp2002). Traducción en español: 2002.

*0642a. NIOSH [2001]. Soluciones simples: ergonomía para trabajadores agrícolas. Cincinnati, OH: Departamento de Salud y Servicios Humanos, Centros para el Control y la Prevención de Enfermedades, Instituto Nacional de Salud y Seguridad Ocupacional, DHHS (NIOSH) Número de Publicación 2001-111(Sp2002). Traducción en español: 2002.

NORA: Disease and Injury: Musculoskeletal Disorders; Work Environment and Workforce: Special Populations at Risk 


\section{FATALITY ASSESSMENT AND CONTROL EVALUATION REPORTS}

*0644. NIOSH [2002]. Three ironworkers die after heavy-lift crane tips over-Wisconsin. Morgantown, WV: Department of Health and Human Services, Public Health Service, Centers for Disease Control and Prevention, National Institute for Occupational Safety and Health, Fatality Assessment and Control Evaluation (FACE) Report No. 1999-11.

*0645. NIOSH [2002]. A 14-year-old laborer dies after a stored piece of hoisting apparatus fell on him at an automobile repossession yard-Pennsylvania. Morgantown, WV: Department of

Health and Human Services, Public Health Service, Centers for Disease Control and Prevention, National Institute for Occupational Safety and Health, Fatality Assessment and Control Evaluation (FACE) Report No. 2000-04.

*0646. NIOSH [2002]. A 17-year-old window washer dies after falling 180 feet due to a rigging anchor failure-Pennsylvania. Morgantown, WV: Department of Health and Human Services, Public Health Service, Centers for Disease Control and Prevention, National Institute for Occupational Safety and Health, Fatality Assessment and Control Evaluation (FACE) Report No. 2000-08.

*0647. NIOSH [2002]. A 15-year-old male farm laborer dies after the tractor he was operating overturned into a manure pit-Pennsylvania. Morgantown, WV: Department of Health and Human Services, Public Health Service, Centers for Disease Control and Prevention, National Institute for Occupational Safety and Health, Fatality Assessment and Control Evaluation (FACE) Report No. 2000-18.

*0648. NIOSH [2002]. A 16-year-old roofer helper dies after 28-foot fall down an unguarded elevator shaft opening-Pennsylvania. Morgantown, WV: Department of Health and Human Services, Public Health Service, Centers for Disease Control and Prevention, National Institute for Occupational Safety and Health, Fatality Assessment and Control Evaluation (FACE) Report No. 2000-23.

*0649. NIOSH [2002]. A 33-year-old textile worker dies after being pinned by a bobbin lift/dump - North Carolina. Morgantown, WV: Department of Health and Human Services, Public Health Service, Centers for Disease Control and Prevention, National Institute for Occupational Safety and Health, Fatality Assessment and Control Evaluation (FACE) Report No. 2000-24. 


\section{Fatality Assessment and Control Evaluation Reports}

*0650. NIOSH [2002]. Temporary service worker dies after mower rolls over on him - North Carolina. Morgantown, WV: Department of Health and Human Services, Public Health Service, Centers for Disease Control and Prevention, National Institute for Occupational Safety and Health, Fatality Assessment and Control Evaluation (FACE) Report No. 2000-25.

*0651. NIOSH [2002]. Construction laborer dies after being struck in the head by a backhoe bucket - North Carolina. Morgantown, WV: Department of Health and Human Services, Public Health Service, Centers for Disease Control and Prevention, National Institute for Occupational Safety and Health, Fatality Assessment and Control Evaluation (FACE) Report No. 2000-26.

*0652. NIOSH [2002]. A 36-year-old paper factory worker dies from crushing injuries after being caught in a horizontal baler-Pennsylvania. Morgantown, WV: Department of Health and Human Services, Public Health Service, Centers for Disease Control and Prevention, National Institute for Occupational Safety and Health, Fatality Assessment and Control Evaluation (FACE) Report No. 2001-08.

*0653. NIOSH [2002]. A 28-year-old laborer dies after being struck by excavator bucket—North Carolina. Morgantown, WV: Department of Health and Human Services, Public Health Service, Centers for Disease Control and Prevention, National Institute for Occupational Safety and Health, Fatality Assessment and Control Evaluation (FACE) Report No. 2001-09.

*0654. NIOSH [2002]. A 26-year-old emergency medical technician dies in multiple fatality ambulance crash-Kentucky. Morgantown, WV: Department of Health and Human Services, Public Health Service, Centers for Disease Control and Prevention, National Institute for Occupational Safety and Health, Fatality Assessment and Control Evaluation (FACE) Report No. 2001-11.

*0655. NIOSH [2002]. A 14-year-old rental equipment worker dies from asphyxiation after becoming entangled in an electric chain hoist-Colorado. Morgantown, WV: Department of Health and Human Services, Public Health Service, Centers for Disease Control and Prevention, National Institute for Occupational Safety and Health, Fatality Assessment and Control Evaluation (FACE) Report No. 2001-13.

*0656. NIOSH [2002]. A 17-year-old warehouse laborer dies after the forklift he was operating tipped over and crushed him-Arizona. Morgantown, WV: Department of Health and Human Services, Public Health Service, Centers for Disease Control and Prevention, National Institute for Occupational Safety and Health, Fatality Assessment and Control Evaluation (FACE) Report No. 2002-02.

*0657. NIOSH [2002]. Construction laborer dies after being run over and crushed by a grader at a road construction site-North Carolina. Morgantown, WV: Department of Health and Human 
Services, Public Health Service, Centers for Disease Control and Prevention, National Institute for Occupational Safety and Health, Fatality Assessment and Control Evaluation (FACE) Report No. 2002-03.

*0658. NIOSH [2002]. Plumber dies after being crushed between a tandem scissors lift platform and the I-beam frame of a mobile home-Tennessee. Morgantown, WV: Department of Health and Human Services, Public Health Service, Centers for Disease Control and Prevention, National Institute for Occupational Safety and Health, Fatality Assessment and Control Evaluation (FACE) Report No. 2002-04.

*0659. NIOSH [2002]. Truck driver crushed between truck bed and truck frame while greasing universal joints-Tennessee. Morgantown, WV: Department of Health and Human Services, Public Health Service, Centers for Disease Control and Prevention, National Institute for Occupational Safety and Health, Fatality Assessment and Control Evaluation (FACE) Report No. 2002-08. 


\section{FIRE FIGHTER FATALITY INVESTIGATION AND PREVENTION REPORTS}

*0660. NIOSH [2002]. Residential house fire claims the life of one career fire fighter-Florida. Morgantown, WV: Department of Health and Human Services, Public Health Service, Centers for Disease Control and Prevention, National Institute for Occupational Safety and Health, Fire Fighter Fatality Investigation and Prevention Report No. F2000-44.

*0661. NIOSH [2002]. Volunteer fire fighter dies and junior fire fighter is injured after tanker rollover during water shuttle training exercise-Kentucky. Morgantown, WV: Department of

Health and Human Services, Public Health Service, Centers for Disease Control and Prevention, National Institute for Occupational Safety and Health, Fire Fighter Fatality Investigation and Prevention Report No. F2001-01.

*0662. NIOSH [2002]. A fire fighter drowns after attempting to rescue a civilian stranded in flood water - Colorado. Morgantown, WV: Department of Health and Human Services, Public Health Service, Centers for Disease Control and Prevention, National Institute for Occupational Safety and Health, Fire Fighter Fatality Investigation and Prevention Report No. F2001-02.

*0663. NIOSH [2002]. Roof collapse injures four career fire fighters at a church fire-Arkansas. Morgantown, WV: Department of Health and Human Services, Public Health Service, Centers for Disease Control and Prevention, National Institute for Occupational Safety and Health, Fire Fighter Fatality Investigation and Prevention Report No. F2001-03.

*0664. NIOSH [2002]. Two volunteer fire fighters die fighting a basement fire-Illinois. Morgantown, WV: Department of Health and Human Services, Public Health Service, Centers for Disease Control and Prevention, National Institute for Occupational Safety and Health, Fire Fighter Fatality Investigation and Prevention Report No. F2001-08.

*0665. NIOSH [2002]. Supermarket fire claims the life of one career fire fighter and critically injures another career fire fighter-Arizona. Morgantown, WV: Department of Health and Human Services, Public Health Service, Centers for Disease Control and Prevention, National Institute for Occupational Safety and Health, Fire Fighter Fatality Investigation and Prevention Report No. F2001-13.

*0666. NIOSH [2002]. Career fire fighter dies after falling through the floor fighting a structure fire at a local residence - Ohio. Morgantown, WV: Department of Health and Human Services, Public Health Service, Centers for Disease Control and Prevention, National Institute for 


\section{Fire Fighter Fatality Investigation and Prevention Reports}

Occupational Safety and Health, Fire Fighter Fatality Investigation and Prevention Report No. F2001-16.

*0667. NIOSH [2002]. Career fire fighter dies after becoming trapped by fire in apartment building-New Jersey. Morgantown, WV: Department of Health and Human Services, Public Health Service, Centers for Disease Control and Prevention, National Institute for Occupational Safety and Health, Fire Fighter Fatality Investigation and Prevention Report No. F2001-18.

*0668. NIOSH [2002]. Fire fighter dies after completing job task evaluation-Alabama. Morgantown, WV: Department of Health and Human Services, Public Health Service, Centers for Disease Control and Prevention, National Institute for Occupational Safety and Health, Fire Fighter Fatality Investigation and Prevention Report No. F2001-25.

*0669. NIOSH [2002]. Career fire fighter dies from injuries when stationary fill tank becomes over pressurized and suffers catastrophic failure - California. Morgantown, WV: Department of Health and Human Services, Public Health Service, Centers for Disease Control and Prevention, National Institute for Occupational Safety and Health, Fire Fighter Fatality Investigation and Prevention Report No. F2001-26.

*0670. NIOSH [2002]. Fire fighter receives severe electrical shock causing cardiac complications, forcing his retirement, and eventually causing his death-Massachusetts. Morgantown, WV: Department of Health and Human Services, Public Health Service, Centers for Disease Control and Prevention, National Institute for Occupational Safety and Health, Fire Fighter Fatality Investigation and Prevention Program Report No. F2001-28.

*0671. NIOSH [2002]. Fire fighter suffers fatal heart attack after returning home from fire- Iowa. Morgantown, WV: Department of Health and Human Services, Public Health Service, Centers for Disease Control and Prevention, National Institute for Occupational Safety and Health, Fire Fighter Fatality Investigation and Prevention Program Report No. F2001-30.

*0672. NIOSH [2002]. Fire fighter suffers a fatal heart attack during a training exercise - Michigan. Morgantown, WV: Department of Health and Human Services, Public Health Service, Centers for Disease Control and Prevention, National Institute for Occupational Safety and Health, Fire Fighter Fatality Investigation and Prevention Program Report No. F2001-31.

*0673. NIOSH [2002]. Fire fighter dies at three-alarm structure fire-New York. Morgantown, WV: Department of Health and Human Services, Public Health Service, Centers for Disease Control and Prevention, National Institute for Occupational Safety and Health, Fire Fighter Fatality Investigation and Prevention Program Report No. F2001-32.

*0673a. NIOSH [2002]. High-rise apartment fire claims the life of one career fire fighter (captain) and injures another career fire fighter (captain)—-Texas. Morgantown, WV: Department 


\section{Fire Fighter Fatality Investigation and Prevention Reports}

of Health and Human Services, Public Health Service, Centers for Disease Control and Prevention, National Institute for Occupational Safety and Health, Fire Fighter Fatality Investigation and Prevention Report No. F2001-33.

*0674. NIOSH [2002]. Fire fighter suffers probable heart attack at fire station-Kentucky. Morgantown, WV: Department of Health and Human Services, Public Health Service, Centers for Disease Control and Prevention, National Institute for Occupational Safety and Health, Fire Fighter Fatality Investigation and Prevention Program Report No. F2001-34.

*0675. NIOSH [2002]. Volunteer fire fighter drowns during multi-agency dive-rescue exercise-Illinois. Morgantown, WV: Department of Health and Human Services, Public Health Service, Centers for Disease Control and Prevention, National Institute for Occupational Safety and Health, Fire Fighter Fatality Investigation and Prevention Report No. F2001-35.

*0676. NIOSH [2002]. Volunteer fire fighter dies when tanker crashes into boulder and treeOregon. Morgantown, WV: Department of Health and Human Services, Public Health Service, Centers for Disease Control and Prevention, National Institute for Occupational Safety and Health, Fire Fighter Fatality Investigation and Prevention Report No. F2001-36.

*0677. NIOSH [2002]. Fire fighter suffers heart arrhythmia and dies at wild land fireWashington. Morgantown, WV: Department of Health and Human Services, Public Health Service, Centers for Disease Control and Prevention, National Institute for Occupational Safety and Health, Fire Fighter Fatality Investigation and Prevention Program Report No. F2001-37.

*0678. NIOSH [2002]. Volunteer fire fighter dies and two others are injured during live-burn training-New York. Morgantown, WV: Department of Health and Human Services, Public Health Service, Centers for Disease Control and Prevention, National Institute for Occupational Safety and Health, Fire Fighter Fatality Investigation and Prevention Report No. F2001-38.

*0679. NIOSH [2002]. Volunteer fire fighter killed and an assistant chief injured in tanker truck crash-West Virginia. Morgantown, WV: Department of Health and Human Services, Public Health Service, Centers for Disease Control and Prevention, National Institute for Occupational Safety and Health, Fire Fighter Fatality Investigation and Prevention Report No. F2001-39.

*0680. NIOSH [2002]. Fire fighter suffers cardiac arrest at structure fire-Illinois. Morgantown, WV: Department of Health and Human Services, Public Health Service, Centers for Disease Control and Prevention, National Institute for Occupational Safety and Health, Fire Fighter Fatality Investigation and Prevention Program Report No. F2001-40.

*0681. NIOSH [2002]. Fire fighter dies during fire department standby-Arizona. Morgantown, WV: Department of Health and Human Services, Public Health Service, Centers for Disease 


\section{Fire Fighter Fatality Investigation and Prevention Reports}

Control and Prevention, National Institute for Occupational Safety and Health, Fire Fighter Fatality Investigation and Prevention Program Report No. F2002-02.

*0682. NIOSH [2002]. Fire fighter suffers cardiac arrest while responding to a structure fireTexas. Morgantown, WV: Department of Health and Human Services, Public Health Service, Centers for Disease Control and Prevention, National Institute for Occupational Safety and Health, Fire Fighter Fatality Investigation and Prevention Program Report No. F2002-03.

*0683. NIOSH [2002]. Motor-vehicle incident claims life of volunteer fire fighter-Ohio. Morgantown, WV: Department of Health and Human Services, Public Health Service, Centers for Disease Control and Prevention, National Institute for Occupational Safety and Health, Fire Fighter Fatality Investigation and Prevention Report No. F2002-04.

*0684. NIOSH [2002]. Fire fighter dies at kitchen fire-North Carolina. Morgantown, WV: Department of Health and Human Services, Public Health Service, Centers for Disease Control and Prevention, National Institute for Occupational Safety and Health, Fire Fighter Fatality Investigation and Prevention Program Report No. F2002-08.

*0685. NIOSH [2002]. Fire fighter dies while exercising-Florida. Morgantown, WV: Department of Health and Human Services, Public Health Service, Centers for Disease Control and Prevention, National Institute for Occupational Safety and Health, Fire Fighter Fatality Investigation and Prevention Program Report No. F2002-09.

*0686. NIOSH [2002]. Volunteer fire fighter dies after tanker truck is struck by freight trainKentucky. Morgantown, WV: Department of Health and Human Services, Public Health Service, Centers for Disease Control and Prevention, National Institute for Occupational Safety and Health, Fire Fighter Fatality Investigation and Prevention Report No. F2002-10.

*0687. NIOSH [2002]. Volunteer fire fighter killed and career chief injured during residential house fire-Tennessee. Morgantown, WV: Department of Health and Human Services, Public Health Service, Centers for Disease Control and Prevention, National Institute for Occupational Safety and Health, Fire Fighter Fatality Investigation and Prevention Report No. F2002-12.

*0688. NIOSH [2002]. Career fire fighter dies of injuries he received while working on fireground-Michigan. Morgantown, WV: Department of Health and Human Services, Public Health Service, Centers for Disease Control and Prevention, National Institute for Occupational Safety and Health, Fire Fighter Fatality Investigation and Prevention Report No. F2002-14.

*0689. NIOSH [2002]. Volunteer fire fighter dies and two are injured in engine rollover- Alabama. Morgantown, WV: Department of Health and Human Services, Public Health Service, Centers for Disease Control and Prevention, National Institute for Occupational Safety and Health, Fire Fighter Fatality Investigation and Prevention Report No. F2002-16. 


\section{Fire Fighter Fatality Investigation and Prevention Reports}

*0690. NIOSH [2002]. Fire fighter dies during the night at fire station-Kansas. Morgantown, WV: Department of Health and Human Services, Public Health Service, Centers for Disease Control and Prevention, National Institute for Occupational Safety and Health, Fire Fighter Fatality Investigation and Prevention Program Report No. F2002-17.

*0691. NIOSH [2002]. Fire fighter dies during live fire training - North Carolina. Morgantown, WV: Department of Health and Human Services, Public Health Service, Centers for Disease Control and Prevention, National Institute for Occupational Safety and Health, Fire Fighter Fatality Investigation and Prevention Program Report No. F2002-19.

*0692. NIOSH [2002]. Junior fire fighter killed while responding to fire alarm on his bicyclePennsylvania. Morgantown, WV: Department of Health and Human Services, Public Health Service, Centers for Disease Control and Prevention, National Institute for Occupational Safety and Health, Fire Fighter Fatality Investigation and Prevention Report No. F2002-21.

*0693. NIOSH [2002]. Fire fighter dies during the night at fire station-Missouri. Morgantown, WV: Department of Health and Human Services, Public Health Service, Centers for Disease Control and Prevention, National Institute for Occupational Safety and Health, Fire Fighter Fatality Investigation and Prevention Program Report No. F2002-27.

*0694. NIOSH [2002]. Fire fighter suffers probable heart attack at condominium fire-South Carolina. Morgantown, WV: Department of Health and Human Services, Public Health Service, Centers for Disease Control and Prevention, National Institute for Occupational Safety and Health, Fire Fighter Fatality Investigation and Prevention Program Report No. F2002-30.

*0694a. NIOSH [2002]. Fire fighter dies during night at fire station-North Carolina. Cincinnati, OH: Department of Health and Human Services, Public Health Service, Centers for Disease Control and Prevention, National Institute for Occupational Safety and Health, Fire Fighter Fatality Investigation and Prevention Program Report No. F2002-33. 


\section{TECHNOLOGY NEWS}

*0695. NIOSH [2002]. Technology news 494. NIOSH releases new expert miner training video. Pittsburgh, PA: Department of Health and Human Services, Public Health Service, Centers for Disease Control and Prevention, National Institute for Occupational Safety and Health.

*0696. NIOSH [2002]. Technology news 495. NIOSH releases new educational video. Recovery of Farmington No. 9-an interview with Danny Kuhn. Pittsburgh, PA: Department of Health and Human Services, Public Health Service, Centers for Disease Control and Prevention, National Institute for Occupational Safety and Health. NORA: Research Tools and Approaches: Intervention Effectiveness Research

*0697. NIOSH [2002]. Technology news 496. NIOSH releases a new computer-based training exercise called MERITS. Pittsburgh, PA: Department of Health and Human Services, Public Health Service, Centers for Disease Control and Prevention, National Institute for Occupational Safety and Health.

*0698. NIOSH [2002]. Technology news 497. You are my sunshine. NIOSH releases video on the Sunshine Mine fire. Pittsburgh, PA: Department of Health and Human Services, Public Health Service, Centers for Disease Control and Prevention, National Institute for Occupational Safety and Health.

*0699. NIOSH [2002]. Technology news 498. Multiple fire sensors for mine fire detection and nuisance discrimination. Pittsburgh, PA: Department of Health and Human Services, Public Health Service, Centers for Disease Control and Prevention, National Institute for Occupational Safety and Health.

NORA: Work Environment Workforce: Emerging Technologies

*0700. NIOSH [2002]. Technology news 499. Using propeller fans to improve ventilation in large-entry stone mines. Pittsburgh, PA: Department of Health and Human Services, Public Health Service, Centers for Disease Control and Prevention, National Institute for Occupational Safety and Health.

NORA: Research Tools and Approaches: Control Technology and Personal Protective Equipment

*0701. NIOSH [2002]. Technology news 500. Using in-place stone stoppings to direct air in underground stone mines. Pittsburgh, PA: Department of Health and Human Services, Public Health Service, Centers for Disease Control and Prevention, National Institute for Occupational Safety and Health.

NORA: Research Tools and Approaches: Control Technology and Personal Protective Equipment 


\section{KEYWORD INDEX}

\begin{tabular}{|c|c|}
\hline Keyword & Citation Number(s) \\
\hline Abatement & $* 0586$ \\
\hline Abrasives & $* 0399$ \\
\hline Accident & $* 0142 * 0333 * 0354$ \\
\hline Acetylation & $* 0351$ \\
\hline Acid & $* 0158 * 0233 * 0289 * 0319 * 0431 \mathrm{a} * 0546 * 0548 \mathrm{~b}$ \\
\hline Adenocarcinoma & $* 0237 * 0381 * 0515$ \\
\hline Aerosol & $\begin{array}{l}* 0007 * 0008 * 0010 * 0094 * 0105 * 0173 * 0179 * 0180 * 0181 * 0203 \\
* 0260 * 0323 * 0324 * 0324 \mathrm{a} * 0325 * 0341 * 0469 * 0472 * 0499\end{array}$ \\
\hline Agrícolas & $* 0642 \mathrm{a}$ \\
\hline Agricultural & $* 0204 * 0229 * 0442 * 0454 * 0479$ \\
\hline Agriculture & $* 0073 * 0106$ \\
\hline Air & $* 0029 * 0082 * 0275 * 0397 * 0398 * 0701$ \\
\hline Air Force & $* 0594 * 0595$ \\
\hline Air-purifying & $* 0469 * 0541$ \\
\hline Airborne & $\begin{array}{l}* 0150 * 0172 * 0173 * 0185 * 0203 * 0346 * 0376 * 0450 * 0451 * 0452 \\
* 0502 * 0505 * 0625\end{array}$ \\
\hline Aircraft & $* 0030 * 0555 * 0594 * 0595$ \\
\hline Airflow & $* 0389 * 0413$ \\
\hline Airport & $* 0583$ \\
\hline Alachlor & $* 0316$ \\
\hline Aliphatic & $* 0014 * 0015$ \\
\hline $\begin{array}{l}\text { Allergic and Irritant Dermatitis } \\
\text { [NORA] }\end{array}$ & $\begin{array}{l}* 0051 * 0130 * 0191 * 0246 * 0248 * 0249 * 0250 * 0251 * 0316 * 0545 \\
* 0546\end{array}$ \\
\hline Allergy & $\begin{array}{l}* 0003 * 0041 * 0051 * 0130 * 0191 * 0200 * 0246 * 0248 * 0249 * 0250 \\
* 0251 * 0289 * 0301 * 0316 * 0318 * 0504 * 0545 * 0546\end{array}$ \\
\hline Alumino-silicate & $* 0392 \mathrm{a} * 0548 \mathrm{a}$ \\
\hline Aluminum & $* 0114$ \\
\hline Alveolar & $* 0002 * 0181 * 0224 * 0310$ \\
\hline Alzheimer & $* 0100$ \\
\hline Amines & $* 0202 * 0589$ \\
\hline Ammonia & $* 0587$ \\
\hline Amphetamines & $* 0492$ \\
\hline Anhydride & $* 0318 * 0319$ \\
\hline Anthracis Bacillus & $* 0032 * 0236 * 0259 * 0281 * 0417 \mathrm{a}$ \\
\hline Anthrax & $* 0033 * 0037 * 0281 * 0372 a * 0428 a * 0559 a * 0627$ \\
\hline Antioxidant & $* 0130 * 0158 * 0171 * 0191 * 0250 * 0439 * 0463$ \\
\hline Apoptosis & $* 0093 * 0166 * 0295 * 0392 \mathrm{a} * 0418 * 0432 * 0478 * 0479 * 0543 * 0550$ \\
\hline Arginine & $* 0310$ \\
\hline Arrest & $* 0320 * 0321 * 0322 * 0680 * 0682$ \\
\hline Arsenic & $* 0254 * 0255$ \\
\hline Arsenite-induced & $* 0362$ \\
\hline Arthritis & $* 0057 * 0208$ \\
\hline Asbestos & $* 0025 * 0159 * 0162 * 0409$ \\
\hline Ascorbic & $* 0158$ \\
\hline
\end{tabular}


VIII. Keyword Index

\begin{tabular}{|c|c|}
\hline Keyword & Citation Number(s) \\
\hline Aspergillus & $* 0095$ \\
\hline Asphalt & $* 0168 * 0461 * 0531 * 0549 * 0568 * 0577$ \\
\hline Asphyxiants & *0192 \\
\hline Asphyxiation & $* 0655$ \\
\hline Asthma & $\begin{array}{l}* 0025 * 0031 * 0056 * 0108 * 0109 * 0112 * 0144 * 0145 * 0154 * 0156 \\
* 0174 * 0176 * 0199 * 0200 * 0205 * 0210 * 0300 * 0301 * 0318 * 0319 \\
* 0325 * 0327 * 0328 * 0334 * 0370 * 0386 * 0389 * 0394 * 0395 * 0405 \\
* 0406 * 0412 * 0413 * 0446 * 0447 * 0448 * 0590 * 0597 * 0598 * 0619 \\
* 0630\end{array}$ \\
\hline $\begin{array}{l}\text { Asthma and Chronic Obstructive } \\
\text { Pulmonary Disease [NORA] }\end{array}$ & $\begin{array}{l}* 0025 * 0031 * 0056 * 0109 * 0112 * 0144 * 0145 * 0154 * 0156 * 0174 \\
* 0199 * 0200 * 0205 * 0210 * 0300 * 0301 * 0318 * 0319 * 0325 * 0327 \\
* 0328 * 0334 * 0370 * 0386 * 0389 * 0394 * 0395 * 0405 * 0406 * 0412 \\
* 0413 * 0446 * 0447 * 0448 * 0619 * 0630\end{array}$ \\
\hline Astrocyte & $* 0458$ \\
\hline Atomic & $* 0380 * 0517$ \\
\hline Attacks & $* 0185 * 0481 * 0625$ \\
\hline Audiometric & $* 0194$ \\
\hline Auditory & $* 0123 * 0279$ \\
\hline Automobile & $* 0645$ \\
\hline Automotive & $* 0477 * 0590 * 0591$ \\
\hline Autorops & $* 0475$ \\
\hline Bacillus Calmette-Guerin & $* 0238$ \\
\hline Backbelts & $* 0553$ \\
\hline Backhoe & $* 0651$ \\
\hline Benzene & $* 0230$ \\
\hline Benzidine & $* 0351$ \\
\hline Beryllium & $* 0243 * 0302 * 0407 * 0408 * 0417 * 0518$ \\
\hline Bicycling & $* 0241$ \\
\hline Bioengineering & $* 0326$ \\
\hline Biological & $* 0185 * 0400 * 0605 * 0625$ \\
\hline Biomarker & $* 0134 * 0519 * 0549$ \\
\hline Biomonitoring & $* 0017 * 0303$ \\
\hline Biosolids & $* 0631$ \\
\hline Birth Defects & $* 0592$ \\
\hline Bites & $* 0585$ \\
\hline Bituminous & $* 0203$ \\
\hline Bladder & $* 0351$ \\
\hline Blasting & $* 0214 * 0333 * 0399 * 0514$ \\
\hline Blood & $* 0036 * 0201 * 0277 * 0326 * 0330 * 0585$ \\
\hline Bloodborne Pathogens & $* 0585$ \\
\hline Boiler & $* 0108 * 0290$ \\
\hline Boilermaker & $* 0108$ \\
\hline Bolters & $* 0396$ \\
\hline Bolting & $* 0465 * 0510 * 0621$ \\
\hline Bolts & $* 0466$ \\
\hline Brain & $* 0126 * 0127 * 0305 * 0486$ \\
\hline 1-Bromopropane & $* 0580 * 0588$ \\
\hline 2-Bromopropane & $* 0580 * 0588$ \\
\hline Bronchiolitis & $* 0144 * 0145 * 0328 * 0447$ \\
\hline
\end{tabular}


VIII. Keyword Index

\begin{tabular}{|c|c|}
\hline Keyword & Citation Number(s) \\
\hline Bronchitis & $* 0108$ \\
\hline Burns & $* 0114$ \\
\hline Burst & $* 0557$ \\
\hline Butter & $* 0120 * 0419 * 0420$ \\
\hline Cadmium & $* 0128 * 0129 * 0263 * 0430 * 0431 * 0581$ \\
\hline Calcium & $* 0143$ \\
\hline Cancer & $\begin{array}{l}* 0025 * 0040 * 0041 * 0042 * 0043 * 0060 * 0090 * 0091 * 0118 * 0128 \\
* 0129 * 0134 * 0147 * 0154 * 0155 * 0158 * 0159 * 0160 * 0162 * 0166 \\
* 0205 * 0221 * 0237 * 0263 * 0268 * 0271 * 0287 * 0320 * 0321 * 0322 \\
* 0351 * 0353 * 0357 * 0362 * 0373 * 0379 \mathrm{a} * 0380 * 0381 * 0399 * 0402 \\
* 0430 * 0431 * 0432 * 0434 * 0435 * 0436 * 0438 * 0500 * 0501 * 0508 \\
* 0509 * 0519 * 0544 * 0548 \mathrm{a} * 0548 \mathrm{~b} * 0585 * 0587 * 0591\end{array}$ \\
\hline Cancer Research Methods [NORA] & $\begin{array}{l}* 0040 * 0041 * 0042 * 0043 * 0060 * 0090 * 0091 * 0118 * 0128 * 0129 \\
* 0134 * 0155 * 0158 * 0159 * 0160 * 0162 * 0166 * 0221 * 0263 * 0320 \\
* 0321 * 0322 * 0351 * 0362 * 0402 * 0430 * 0431 * 0434 * 0435 * 0436 \\
* 0500 * 0501 * 0519\end{array}$ \\
\hline Carbon Black & $* 0003$ \\
\hline Carbon Monoxide & $* 0068 * 0247 * 0384$ \\
\hline Carcinogen & $* 0042 * 0060 * 0254 * 0402$ \\
\hline Carcinoma & $* 0091$ \\
\hline Carpenters & $* 0423$ \\
\hline Cartilage & *0199 \\
\hline CBC & $* 0580$ \\
\hline Chartbook & $* 0610 \mathrm{a} * 0611 * 0612 * 0613 * 0614$ \\
\hline Childhood & $* 0454$ \\
\hline Chloride & $* 0077 * 0078$ \\
\hline Chromium & $* 0040$ \\
\hline Chromosomal & $* 0237 * 0381$ \\
\hline Chronic & $\begin{array}{l}* 0025 * 0031 * 0056 * 0108 * 0109 * 0112 * 0126 * 0144 * 0145 * 0154 \\
* 0156 * 0174 * 0199 * 0200 * 0205 * 0210 * 0300 * 0301 * 0302 * 0318 \\
* 0319 * 0325 * 0327 * 0328 * 0334 * 0370 * 0386 * 0389 * 0394 * 0395 \\
* 0405 * 0406 * 0412 * 0413 * 0446 * 0447 * 0448 * 0619 * 0630\end{array}$ \\
\hline Circular Variables & $* 0257$ \\
\hline Cis-4-[18f]fluoro-l-proline & $* 0292$ \\
\hline Cluster & $* 0592$ \\
\hline Coal & $\begin{array}{l}* 0012 * 0061 * 0085 * 0097 * 0137 * 0161 * 0164 * 0203 * 0204 * 0296 \\
* 0343 * 0355 * 0359 * 0404 * 0441 * 0465 * 0468 * 0502 * 0505 * 0511 \\
* 0544 * 0548 * 0556 * 0560 * 0567 * 0615 * 0638\end{array}$ \\
\hline Coating & $* 0133 * 0433 * 0499$ \\
\hline Colorimetric & $* 0545$ \\
\hline Concrete & $* 0070 * 0071 * 0163$ \\
\hline Confined Space & $* 0309 * 0595$ \\
\hline Conjunctivitis & $* 0583$ \\
\hline Construction & $\begin{array}{l}* 0070 * 0071 * 0108 * 0163 * 0332 * 0342 * 0363 * 0442 * 0455 * 0495 \\
* 0503 * 0539 * 0559 * 0586 * 0651 * 0657\end{array}$ \\
\hline Continuous & $* 0247$ \\
\hline
\end{tabular}


VIII. Keyword Index

\begin{tabular}{|c|c|}
\hline Keyword & Citation Number(s) \\
\hline $\begin{array}{l}\text { Control Technology and Personal } \\
\text { Protective Equipment [NORA] }\end{array}$ & $\begin{array}{l}* 0045 * 0047 * 0062 * 0067 * 0068 * 0069 * 0070 * 0071 * 0076 * 0077 \\
* 0078 * 0079 * 0080 * 0081 * 0082 * 0083 * 0116 * 0124 * 0161 * 0185 \\
* 0203 * 0217 * 0222 * 0223 * 0232 * 0258 * 0261 * 0276 * 0289 * 0290 \\
* 0296 * 0306 * 0309 * 0311 * 0323 * 0324 * 0326 * 0336 * 0337 * 0339 \\
* 0340 * 0341 * 0346 * 0347 * 0350 * 0354 * 0355 * 0356 * 0357 * 0358 \\
* 0359 * 0360 * 0363 * 0365 * 0366 * 0368 * 0369 * 0374 * 0375 * 0391 \\
* 0392 * 0396 * 0397 * 0398 * 0415 * 0428 * 0445 * 0453 * 0464 * 0467 \\
* 0468 * 0469 * 0470 * 0471 * 0475 * 0484 * 0487 * 0488 * 0495 * 0503 \\
* 0514 * 05340053 * 0541 * 0542 * 0545 * 0546 * 0547 * 0560 * 0562 \\
* 0563 * 0564 * 0569 * 0570 * 0571 * 0573 * 0618 * 0631 * 0633 * 0638 \\
* 0700 * 0701\end{array}$ \\
\hline Copper & $* 0243 * 0518$ \\
\hline Core Body Temperature & $* 0593 * 0594$ \\
\hline Coremaking & $* 0587$ \\
\hline Cornea & $* 0589$ \\
\hline Cotton & $* 0044$ \\
\hline Crushed & $* 0656 * 0657 * 0658 * 0659$ \\
\hline Cumene & $* 0250 * 0251 * 0587$ \\
\hline Currency & $* 0135$ \\
\hline Cutaneous & $* 0033 * 0037$ \\
\hline Cytochrome & $* 0168$ \\
\hline Cytokine & $* 0121 * 0216 * 0315 * 0584$ \\
\hline Cytotoxicity & $* 0040 * 0392 \mathrm{a}$ \\
\hline D-glucosaminidase & $* 0063$ \\
\hline Decontamination & $* 0379 * 0581$ \\
\hline Depression & $* 0578$ \\
\hline Dermatitis & $\begin{array}{l}* 0051 * 0130 * 0191 * 0246 * 0248 * 0249 * 0250 * 0251 * 0316 * 0545 \\
* 0546\end{array}$ \\
\hline Dialkyldithiocarbamate & $* 0372$ \\
\hline Diatomaceous & $* 0205$ \\
\hline Diesel & $\begin{array}{l}* 0002 * 0003 * 0020 * 0164 * 0165 * 0167 * 0232 * 0312 * 0390 * 0398 \\
* 0459 * 0473 * 0477 * 0506 * 0565 * 0633 * 0703\end{array}$ \\
\hline Diisocyanate & $* 0051 * 0176 * 0587$ \\
\hline Dimethylaminoethanol & $* 0589$ \\
\hline Dimethylisopropanolamine & $* 0589$ \\
\hline 4,4'-Diphenylmethane & $* 0587$ \\
\hline Disabilities & $* 0585$ \\
\hline Disease and Injury [NORA] & $\begin{array}{l}* 0013 * 0025 * 0031 * 0046 * 0051 * 0052 * 0054 * 0056 * 0057 * 0062 \\
* 0073 * 0074 * 0075 * 0079 * 0080 * 0084 * 0088 * 0089 * 0099 * 0101 \\
* 0109 * 0112 * 0119 * 0121 * 0123 * 0130 * 0144 * 0145 * 0151 * 0152 \\
* 0154 * 0156 * 0174 * 0191 * 0192 * 0193 * 0194 * 0195 * 0196 * 0197 \\
* 0199 * 0200 * 0205 * 0210 * 0217 * 0218 * 0219 * 0220 * 0222 * 0223 \\
* 0225 * 0226 * 0238 * 0239 * 0240 * 0241 * 0246 * 0248 * 0249 * 0250 \\
* 0251 * 0261 * 0279 * 0288 * 0289 * 0299 * 0300 * 0301 * 0303 * 0306 \\
* 0316 * 0318 * 0319 * 0325 * 0326 * 0327 * 0328 * 0334 * 0335 * 0358 \\
* 0363 * 0370 * 0371 * 0375 * 0383 * 0386 * 0389 * 0391 * 0394 * 0395 \\
* 0405 * 0406 * 0412 * 0413 * 0415 * 0421 * 0422 * 0428 \mathrm{a} * 0429 * 0446 \\
* 0447 * 0448 * 0456 * 0475 * 0495 * 0522 * 0529 * 0545 * 0546 * 0547 \\
* 0553 * 0562 * 0563 * 0564 * 0619 * 0630 * 0632 * 0639 \\
\end{array}$ \\
\hline
\end{tabular}


VIII. Keyword Index

\begin{tabular}{|c|c|}
\hline Keyword & Citation Number(s) \\
\hline DMAE & *0589 \\
\hline$\overline{\text { DMIPA }}$ & $* 0589$ \\
\hline DNA & $* 0160 * 0288 * 0500$ \\
\hline Dopaminergic & $* 0126 * 0127 * 0265$ \\
\hline Dosimeter & $* 0502$ \\
\hline Dosimetry & $* 0148$ \\
\hline Drill & $* 0286 * 0355 * 626 a$ \\
\hline Dry-cleaning & $* 0067 * 0069 * 0081$ \\
\hline Drywall & $* 0363 * 0495$ \\
\hline Dust & $\begin{array}{l}* 0012 * 0044 * 0061 * 0097 * 0133 * 0136 * 0137 * 0163 * 0164 * 0203 \\
* 0229 * 0355 * 0360 * 0368 * 0369 * 0396 * 0432 * 0433 * 0437 * 0441 \\
* 0479 * 0498 * 0502 * 0504 * 0548 * 0548 \mathrm{a}\end{array}$ \\
\hline Dynamic Loading & $* 0306$ \\
\hline Educational & $* 0272 * 0457 * 0696$ \\
\hline Electrical Safety & $* 0616$ \\
\hline Electroanalysis & $* 0277$ \\
\hline Electroplating & *0592 \\
\hline Emergency & $* 0445 * 0571 * 0604 * 0654$ \\
\hline Emerging Technologies [NORA] & $* 0378 * 0390 * 0485 * 0512 * 0513 * 0699$ \\
\hline Endocrine & $* 0226$ \\
\hline Endothelial & $* 0090 * 0091$ \\
\hline Endotoxin & $* 0044 * 0229 * 0313$ \\
\hline Energy & $* 0375 * 0380 * 0428 * 0450 * 0517$ \\
\hline Engineering & $\begin{array}{l}* 0068 * 0069 * 0077 * 0078 * 0346 * 0358 * 0375 * 0388 * 0389 * 0401 \\
* 0424 * 0476 * 0520 * 0531 * 0532 * 0538 * 0564 * 0575 * 0580\end{array}$ \\
\hline Engineers & $* 0326 * 0333 * 0383 * 0475 * 0477 * 0514$ \\
\hline Environmental & $\begin{array}{l}* 0027 * 0156 * 0281 * 0334 * 0370 * 0379 * 0520 * 0538 * 0545 * 0546 \\
* 0578 * 0585 * 0596\end{array}$ \\
\hline Epidemiologic & $* 0023 * 0024 * 0102 * 0206 * 0230 * 0428 \mathrm{a}$ \\
\hline Epidemiological & $* 0023 * 0024$ \\
\hline Epidemiology & $* 0036 * 0207 * 0300 * 0553$ \\
\hline Epidermal & $* 0251 * 0255 * 0321$ \\
\hline Epithelium & $* 0120 * 0384 * 0385 * 0444 * 0561$ \\
\hline Ergonomics & $\begin{array}{l}* 0073 * 0074 * 0084 * 0088 * 0089 * 0115 * 0116 * 0138 * 0363 * 0371 \\
* 0391 * 0400 * 0429 * 0495 * 0522 * 0579\end{array}$ \\
\hline Estrogen & $* 0233 * 0305$ \\
\hline Exercise & $* 0559 * 0661 * 0672 * 0675 * 0697$ \\
\hline Exhaust & $\begin{array}{l}* 0002 * 0003 * 0020 * 0082 * 0167 * 0232 * 0290 * 0312 * 0390 * 0459 \\
* 0506 * 0565 * 0581 * 0703\end{array}$ \\
\hline Explosives & $* 0333 * 0514$ \\
\hline $\begin{array}{l}\text { Exposure Assessment Methods } \\
\text { [NORA] }\end{array}$ & $\begin{array}{l}* 0005 * 0007 * 0008 * 0010 * 0014 * 0015 * 0017 * 0020 * 0023 * 0024 \\
* 0025 * 0049 * 0086 * 0087 * 0094 * 0095 * 0096 * 0099 * 0102 * 0103 \\
* 0105 * 0113 * 0133 * 0137 * 0150 * 0164 * 0175 * 0177 * 0178 * 0179 \\
* 0180 * 0181 * 0183 * 0184 * 0198 * 0211 * 0236 * 0243 * 0245 * 0247 \\
* 0259 * 0260 * 0274 * 0275 * 0277 * 0292 * 0303 * 0332 * 0338 * 0361 \\
* 0387 * 0388 * 0392 \mathrm{a} * 0399 * 0407 * 0408 * 0409 * 0410 * 0414 * 0416 \\
* 0417 * 0432 * 0433 * 0437 * 0438 * 0440 * 0441 * 0443 * 0450 * 0451 \\
* 0452 * 0456 * 0472 * 0473 * 0477 * 0499 * 0502 * 0518 * 0524 * 0526 \\
* 0548 * 0548 \mathrm{a} * 0548 \mathrm{~b} * 0572 * 0617 * 0633 * 0703 \\
\end{array}$ \\
\hline
\end{tabular}


VIII. Keyword Index

\begin{tabular}{|c|c|}
\hline Keyword & Citation Number(s) \\
\hline Exposure Limits & $* 0410$ \\
\hline Exposure-response & $* 0006 * 0174 * 0175 * 0180$ \\
\hline Eye & $* 0234 * 0423$ \\
\hline Fall & $* 0342 * 0474 * 0503 * 0532 * 0597 * 0646 * 0648 * 0666$ \\
\hline Farm & $* 0049 * 0153 * 0647 * 0696$ \\
\hline Fatal & $* 0019 * 0064 * 0199 * 0333 * 0403 * 0610 a * 0611$ \\
\hline Fatalities & $* 0018 * 0030 * 0110$ \\
\hline Fatality & $\begin{array}{l}* 0110 * 0343 * 0623 * 0635 * 0644 * 0645 * 0646 * 0647 * 0648 * 0649 \\
* 0650 * 0651 * 0652 * 0653 * 0654 * 0655 * 0656 * 0657 * 0658 * 0659 \\
* 0660 * 0661 * 0662 * 0663 * 0664 * 0665 * 0666 * 0667 * 0668 * 0669 \\
* 0670 * 0671 * 0672 * 0673 * 0674 * 0675 * 0676 * 0677 * 0678 * 0679 \\
* 0680 * 0681 * 0682 * 0683 * 0684 * 0685 * 0686 * 0687 * 0688 * 0689 \\
* 0690 * 0691 * 0692 * 0693 * 0694\end{array}$ \\
\hline Feller-bunchers & $* 0013$ \\
\hline Female & $* 0126 * 0303$ \\
\hline $\begin{array}{l}\text { Fertility and Pregnancy } \\
\text { Abnormalities [NORA] }\end{array}$ & $\begin{array}{l}* 0099 * 0101 * 0121 * 0151 * 0152 * 0196 * 0225 * 0226 * 0241 * 0288 \\
* 0303 * 0632\end{array}$ \\
\hline Fibroblasts & $* 0320$ \\
\hline Fibrosis & $* 0278 * 0292 * 0294 * 0551$ \\
\hline Filter & $\begin{array}{l}* 0007 * 0008 * 0010 * 0014 * 0045 * 0061 * 0339 * 0340 * 0341 * 0365 \\
* 0366 * 0428 * 0438 * 0453 * 0470 * 0471 * 0472 * 0473 * 0487 * 0488 \\
\end{array}$ \\
\hline Filtering-facepiece & $* 0045 * 0365 * 0453$ \\
\hline Fire & $\begin{array}{l}* 0018 * 0114 * 0165 * 0378 * 0390 * 0605 * 0606 * 0623 * 0635 * 0660 \\
* 0661 * 0662 * 0663 * 0664 * 0665 * 0666 * 0667 * 0668 * 0669 * 0670 \\
* 0671 * 0672 * 0673 * 0673 a * 0674 * 0675 * 0676 * 0677 * 0678 * 0679 \\
* 0680 * 0681 * 0682 * 0683 * 0684 * 0685 * 0686 * 0687 * 0688 * 0689 \\
* 0690 * 0691 * 0692 * 0693 * 0694 * 0698 * 0699\end{array}$ \\
\hline Fire Fighter & $\begin{array}{l}* 0606 * 0623 * 0635 * 0660 * 0661 * 0662 * 0663 * 0664 * 0665 * 0666 \\
* 0667 * 0668 * 0669 * 0670 * 0671 * 0672 * 0673 * 0673 \mathrm{a} * 0674 * 0675 \\
* 0676 * 0677 * 0678 * 0679 * 0680 * 0681 * 0682 * 0683 * 0684 * 0685 \\
* 0686 * 0687 * 0688 * 0689 * 0690 * 0691 * 0692 * 0693 * 0694 * 0694 \mathrm{a} \\
\end{array}$ \\
\hline Fishing & $* 0048 * 0637$ \\
\hline Fit-test & $* 0045 * 0350 * 0453 * 0484 * 0570 * 0571 * 0573$ \\
\hline Florists & *0327 \\
\hline Foam Fabrication & $* 0580$ \\
\hline Forklift & $* 0656$ \\
\hline Formaldehyde & $* 0587$ \\
\hline Foundry & $* 0569 * 0572$ \\
\hline Frequency Distribution & $* 0011$ \\
\hline Fuel & $* 0226 * 0477 * 0524 * 0594 * 0595$ \\
\hline Fungal Contamination & $* 0598$ \\
\hline Furniture & $* 0077 * 0078$ \\
\hline Gas & $* 0247 * 0324 * 0393 * 0414 * 0459 * 0703$ \\
\hline Gene & $\begin{array}{l}* 0009 * 0065 * 0160 * 0182 * 0203 * 0210 * 0228 * 0250 * 0305 * 0314 \\
* 0324 * 0380 * 0411 * 0433 * 0436 * 0462 * 0475 * 0493 * 0499 * 0517 \\
* 0531\end{array}$ \\
\hline Genotoxic & $* 0433 * 0459 * 0568 * 0703$ \\
\hline Geomechanics & $* 0422$ \\
\hline
\end{tabular}


VIII. Keyword Index

\begin{tabular}{|c|c|}
\hline Keyword & Citation Number(s) \\
\hline Germicidal & $* 0124 * 0276 * 0583$ \\
\hline Glass & $* 0061 * 0581$ \\
\hline Glove & $* 0021 * 0056 * 0062 * 0139 * 0211 * 0222 * 0261 * 0379 * 0546 * 0585$ \\
\hline Glutaraldehyde & $* 0545$ \\
\hline Glutathione & $* 0002$ \\
\hline Gold & $\begin{array}{l}* 0081 * 0120 * 0248 * 0325 * 0389 * 0412 * 0419 * 0420 * 0476 * 0498 \\
* 0531 * 0549 * 0595\end{array}$ \\
\hline Gratification & $* 0227$ \\
\hline Grinding & $* 0070 * 0181 * 0299 * 0324 a$ \\
\hline Ground & $\begin{array}{l}* 0336 * 0359 * 0421 * 0465 * 0466 * 0467 * 0468 * 0474 * 0496 * 0510 \\
* 0538 * 0556 * 0567 * 0576\end{array}$ \\
\hline Gypsum & $* 0096$ \\
\hline Hand & $\begin{array}{l}* 0050 * 0057 * 0070 * 0223 * 0299 * 0326 * 0349 * 0375 * 0392 * 0417 \mathrm{a} \\
* 0456 * 0489 * 0492 * 0574 * 0575 * 0579 * 0596\end{array}$ \\
\hline Headache & $* 0596$ \\
\hline Health Promotion & $* 0287$ \\
\hline Healthcare & $* 0370 * 0597$ \\
\hline Hearing & $\begin{array}{l}* 0054 * 0123 * 0143 * 0192 * 0193 * 0194 * 0195 * 0197 * 0218 * 0219 \\
* 0220 * 0279 * 0484 * 0529 * 0560\end{array}$ \\
\hline Hearing Loss [NORA] & $\begin{array}{l}* 0054 * 0123 * 0143 * 0192 * 0193 * 0194 * 0195 * 0197 * 0218 * 0219 \\
* 0220 * 0279 * 0529\end{array}$ \\
\hline Heat & $* 0593 * 0594 * 0595$ \\
\hline Heavy Equipment & $* 0622 \mathrm{a}$ \\
\hline Hematopoietic & $* 0230$ \\
\hline Hepatic & $* 0524$ \\
\hline Hepatitis & $* 0104 * 0314$ \\
\hline Hepatotoxicity & $* 0127$ \\
\hline Hexamethylenetetramin & $* 0587$ \\
\hline Hoist & $* 0016 * 0645 * 0655$ \\
\hline Hormone & $* 0101 * 0151 * 0225$ \\
\hline Horticultural & $* 0409$ \\
\hline Hospital & $* 0188 * 0256 * 0504 * 0599$ \\
\hline Houseboat & $* 0068$ \\
\hline Housing & $* 0586$ \\
\hline $\begin{array}{l}\text { Heating Ventilation and Air } \\
\text { Conditioning (HVAC) }\end{array}$ & $* 0252 * 0339 * 0340 * 0428 * 0487 * 0488 * 0578$ \\
\hline Hydraulics & $* 0336$ \\
\hline Hydrocarbon & $* 0169 * 0170 * 0591$ \\
\hline Hydrogen Peroxide & $* 0059 * 0118 * 0162$ \\
\hline Hydroxyl & $* 0133$ \\
\hline Hyperosmolar & $* 0385 * 0561$ \\
\hline Hypersensitivity & $* 0584 * 0590$ \\
\hline Hyperthyroidism & $* 0121$ \\
\hline Hypertonic & $* 0384$ \\
\hline Hypotonic & $* 0444$ \\
\hline Immigration & $* 0583$ \\
\hline Immunogenom & $* 0584$ \\
\hline Immunology & $* 0460$ \\
\hline
\end{tabular}


VIII. Keyword Index

\begin{tabular}{|c|c|}
\hline Keyword & Citation Number(s) \\
\hline Immunotoxicology & $* 0319$ \\
\hline Indoor Environment [NORA] & $\begin{array}{l}* 0186 * 0187 * 0252 * 0437 * 0497 * 0498 * 0504 * 0516 * 0555 * 0578 \\
* 0585 * 0596 * 0597 * 0598\end{array}$ \\
\hline Induction & $\begin{array}{l}* 0091 * 0093 * 0097 * 0141 * 0169 * 0171 * 0173 * 0262 * 0392 \mathrm{a} * 0432 \\
* 0461 * 0478 * 0479 * 0540\end{array}$ \\
\hline Infection & $* 0004 * 0104 * 0122 * 0238 * 0239 * 0591 * 0627$ \\
\hline Infectious Diseases [NORA] & $* 0046 * 0238 * 0239 * 0335 * 0428 \mathrm{a} * 0585 * 0639$ \\
\hline Inflammation & $* 0212 * 0213 * 0216 * 0294 * 0295 * 0536 * 0550 * 0551 * 0566$ \\
\hline Inhalation Toxicity & $* 0009$ \\
\hline Injection-molding & $* 0591$ \\
\hline Injuries & $\begin{array}{l}0013 * 0018 * 0019 * 0025 * 0031 * 0046 * 0051 * 0052 * 0054 * 0056 \\
* 0057 * 0058 * 0062 * 0073 * 0074 * 0075 * 0079 * 0080 * 0084 * 0088 \\
* 0089 * 0099 * 0101 * 0106 * 0109 * 0112 * 0119 * 0121 * 0122 * 0123 \\
* 0130 * 0144 * 0145 * 0151 * 0152 * 0154 * 0156 * 0172 * 0174 * 0191 \\
* 0192 * 0193 * 0194 * 0195 * 0196 * 0197 * 0199 * 0200 * 0205 * 0206 \\
* 0210 * 0217 * 0218 * 0219 * 0220 * 0222 * 0223 * 0225 * 0226 * 0238 \\
* 0239 * 0240 * 0241 * 0246 * 0248 * 0249 * 0250 * 0251 * 0261 * 0273 \\
* 0279 * 0288 * 0289 * 0298 * 0299 * 0300 * 0301 * 0303 * 0306 * 0316 \\
* 0318 * 0319 * 0325 * 0326 * 0327 * 0328 * 0334 * 0335 * 0342 * 0349 \\
* 0358 * 0363 * 0367 * 0370 * 0371 * 0375 * 0383 * 0386 * 0389 * 0391 \\
* 0394 * 0395 * 0403 * 0405 * 0406 * 0412 * 0413 * 0415 * 0421 * 0422 \\
* 0423 * 0425 * 0428 \mathrm{a} * 0429 * 0442 * 0446 * 0447 * 0448 * 0454 * 0456 \\
* 0457 * 0458 * 0475 * 0478 * 0495 * 0522 * 0529 * 0530 * 0536 * 0545 \\
* 0546 * 0547 * 0553 * 0562 * 0563 * 0564 * 0609 * 0610 \mathrm{a} * 0612 * 0619 \\
* 0630 * 0632 * 0639 * 0652 * 0661 * 0663 * 0665 * 0669 * 0678 * 0679 \\
* 0687 * 0688 * 0689\end{array}$ \\
\hline Insecticide & $* 0279$ \\
\hline Interferon & $* 0584$ \\
\hline Interleukin & $* 0307 * 0584$ \\
\hline $\begin{array}{l}\text { Intervention Effectiveness Research } \\
\text { [NORA] }\end{array}$ & $\begin{array}{l}* 0013 * 0067 * 0068 * 0069 * 0070 * 0071 * 0081 * 0089 * 0214 * 0232 \\
* 0240 * 0256 * 0290 * 0309 * 0489 * 0529 * 0553 * 0616 * 0696\end{array}$ \\
\hline Ionizing & $* 0380 * 0517$ \\
\hline Irradiation & $* 0124 * 0276$ \\
\hline Irritation & $* 0577 * 0587 * 0596$ \\
\hline Isocyanate & $* 0014 * 0015 * 0274$ \\
\hline Isopropyl Bromide & $* 0580$ \\
\hline Jet Fuel & $* 0524 * 0595$ \\
\hline Job Stress & $\begin{array}{l}* 0119 * 0189 * 0331 * 0486 * 0489 * 0490 * 0578 * 0585 * 0604 * 0640 \\
* 0641\end{array}$ \\
\hline Kaolin & $* 0093 * 0392 \mathrm{a} * 0432$ \\
\hline Karyotyping & $* 0237$ \\
\hline Keratinocytes & $* 0251$ \\
\hline Kidney & $* 0270 * 0524$ \\
\hline Ladder & $* 0457 * 0559$ \\
\hline Laryngeal & $* 0379 a$ \\
\hline Laser & $* 0278 * 0372 \mathrm{a} * 0532$ \\
\hline Latex & $* 0301 * 0372$ \\
\hline
\end{tabular}


VIII. Keyword Index

\begin{tabular}{|c|c|}
\hline Keyword & Citation Number(s) \\
\hline Lead & ${ }^{*} 0036 * 0066 * 0123 * 0201 * 0275 * 0377 * 0537 * 0581 * 0582 * 0586$ \\
\hline Leukemia & $* 0253$ \\
\hline Lift & $* 0084 * 0089 * 0649 * 0658$ \\
\hline Limestone & $* 0061 * 0421$ \\
\hline Line Handlers & $* 0392$ \\
\hline Listeria & $* 0312 * 0565$ \\
\hline Liver & $* 0436 * 0486$ \\
\hline Livestock & $* 0153$ \\
\hline Logging & $* 0013$ \\
\hline Logistic Regression & $* 0149$ \\
\hline Longwall & $* 0404 * 0567$ \\
\hline Low Back Disorders [NORA] & $* 0089 * 0391 * 0547 * 0553$ \\
\hline Lumbar & $* 0429$ \\
\hline Lung & $\begin{array}{l}* 0003 * 0004 * 0025 * 0031 * 0121 * 0124 * 0144 * 0147 * 0148 * 0154 \\
* 0205 * 0215 * 0237 * 0238 * 0239 * 0276 * 0278 * 0283 * 0307 * 0381 \\
* 0389 * 0394 * 0402 * 0434 * 0435 * 0447 * 0461 * 0472 * 0478 * 0515 \\
* 0536 * 0551 * 0568 * 0587\end{array}$ \\
\hline Lupus & *0208 \\
\hline Lymphocyte & $* 0002 * 0238 * 0239$ \\
\hline Machinery & $* 0138 * 0383 * 0584$ \\
\hline Macrophage & $* 0002 * 0093 * 0166 * 0171 * 0224 * 0294 * 0310 * 0551$ \\
\hline Magnetic Field & $* 0183$ \\
\hline Manure & $* 0647$ \\
\hline Materials-handling & $* 0530$ \\
\hline Max Scorings & $* 0235$ \\
\hline MDI & $* 0587$ \\
\hline Mental Retardation & $* 0585$ \\
\hline Mercury & $* 0581$ \\
\hline Metabolite & $* 0096 * 0151 * 0191 * 0316$ \\
\hline Metal & $\begin{array}{l}* 0035 * 0042 * 0043 * 0098 * 0133 * 0150 * 0248 * 0249 * 0323 * 0324 \\
* 0332 * 0360 * 0376 * 0433 * 0450 * 0451 * 0452 * 0590\end{array}$ \\
\hline Metallurgy & $\begin{array}{l}* 0323 * 0337 * 0354 * 0355 * 0360 * 0369 * 0396 * 0398 * 0404 * 0494 \\
* 0530 * 0533 * 0539 * 0558 * 0574 * 0575\end{array}$ \\
\hline Metalworking & $* 0035 * 0098 * 0590$ \\
\hline Methane & $* 0534$ \\
\hline Methylene & $* 0077 * 0078$ \\
\hline Mice & $* 0140 * 0143 * 0248 * 0249 * 0250 * 0265 * 0295 * 0492 * 0525 * 0550$ \\
\hline Microbacterium & $* 0584$ \\
\hline Microbial & $* 0095 * 0505$ \\
\hline Microorganisms & $* 0022 * 0173$ \\
\hline Microseismic & $* 0404$ \\
\hline Microwave & $* 0031 * 0144 * 0145 * 0346 * 0447 * 0448$ \\
\hline Mild-steel & $* 0269$ \\
\hline Miner & $* 0161 * 0296 * 0357 * 0412 * 0494 * 0533 * 0560 * 0600 * 0634 * 0695$ \\
\hline
\end{tabular}


VIII. Keyword Index

\begin{tabular}{|c|c|}
\hline Keyword & Citation Number(s) \\
\hline Mining & $\begin{array}{l}* 0047 * 0137 * 0142 * 0234 * 0240 * 0333 * 0336 * 0337 * 0343 * 0354 \\
* 0355 * 0359 * 0360 * 0367 * 0369 * 0376 * 0377 * 0378 * 0382 * 0390 \\
* 0396 * 0397 * 0398 * 0404 * 0421 * 0422 * 0440 * 0441 * 0445 * 0465 \\
* 0466 * 0467 * 0468 * 0474 * 0485 * 0494 * 0496 * 0502 * 0505 * 0510 \\
* 0511 * 0512 * 0513 * 0530 * 0532 * 0533 * 0535 * 0537 * 0538 * 0539 \\
* 0548 * 0556 * 0557 * 0558 * 0559 * 0567 * 0574 * 0575 * 0576 * 0600 \\
* 0614 * 0622 * 0629 * 0633 * 0638 * 0698 * 0699 * 0700 * 0701\end{array}$ \\
\hline Mixed Exposures [NORA] & $\begin{array}{l}* 0002 * 0003 * 0004 * 0027 * 0097 * 0108 * 0113 * 0120 * 0133 * 0167 \\
* 0168 * 0294 * 0295 * 0310 * 0312 * 0313 * 0325 * 0329 * 0388 * 0389 \\
* 0392 \mathrm{a} * 0419 * 0420 * 0432 * 0433 * 0461 * 0477 * 0506 * 0536 * 0544 \\
* 0548 \mathrm{a} * 0549 * 0550 * 0565 * 0566 * 0568 * 0703\end{array}$ \\
\hline Modeling & $* 0180 * 0317 * 0424 * 0520 * 0523 * 0562 * 0563$ \\
\hline Models & $* 0082 * 0119 * 0148 * 0197 * 0223 * 0365 * 0525$ \\
\hline Mold & $* 0497 * 0597$ \\
\hline Monitoring & $* 0016 * 0020 * 0103 * 0141 * 0262 * 0332 * 0393 * 0437 * 0450 * 0474$ \\
\hline Monocytogenes & $* 0312 * 0565$ \\
\hline Mortality & $* 0025 * 0153 * 0154 * 0174 * 0179 * 0230 * 0269 * 0270 * 0272 * 0526$ \\
\hline Motion Editing & $* 0547$ \\
\hline Motor Vehicle & *0683 \\
\hline Mower & $* 0650$ \\
\hline Musculoskeletal Disorders [NORA] & $\begin{array}{l}* 0052 * 0057 * 0062 * 0073 * 0074 * 0075 * 0084 * 0088 * 0223 * 0261 \\
* 0299 * 0306 * 0326 * 0358 * 0371 * 0375 * 0400 * 0429 * 0456 * 0562 \\
* 0563 * 0564\end{array}$ \\
\hline Mutagen & $* 0155 * 0435 * 0436 * 0477 * 0500 * 0568$ \\
\hline Mycobacterium & $* 0590$ \\
\hline N-propyl Bromide & $* 0580$ \\
\hline $\begin{array}{l}\text { National Occupational Research } \\
\text { Agenda [NORA] }\end{array}$ & $* *$ see NORA index $* *$ \\
\hline Nausea & $* 0596$ \\
\hline Necrosis & $* 0120 * 0166 * 0171 * 0176 * 0298$ \\
\hline Needlestick & $* 0122$ \\
\hline Neon Signs & $* 0581$ \\
\hline Neurobehavioral & $* 0588$ \\
\hline Neuroendocrine & $* 0189$ \\
\hline Neurotoxic & $* 0099 * 0126 * 0127 * 0265 * 0280 * 0458 * 0492$ \\
\hline NHANES & $* 0413$ \\
\hline NIOSH Methods & $* 0150 * 0345$ \\
\hline Nitric & $* 0215 * 0352$ \\
\hline Nitrosamines & ${ }_{* 0591}^{*}$ \\
\hline Noise & $\begin{array}{l}* 0054 * 0143 * 0192 * 0193 * 0194 * 0195 * 0218 * 0219 * 0220 * 0279 \\
* 0288 * 0582\end{array}$ \\
\hline Nonmetal & $* 0398$ \\
\hline NORA & $* *$ see NORA index $* *$ \\
\hline Nose & $* 0009 * 0591 * 0596$ \\
\hline Nuclear & $* 0024 * 0121 * 0166 * 0169$ \\
\hline Numerical Methods & $* 0554$ \\
\hline Obesity & $* 0264$ \\
\hline Obliterans & $* 0144 * 0145 * 0328 * 0447$ \\
\hline
\end{tabular}


VIII. Keyword Index

\begin{tabular}{|c|c|}
\hline Keyword & Citation Number(s) \\
\hline Occupational Health & $\begin{array}{l}* 0026 * 0032 * 0192 * 0244 * 0297 * 0394 * 0457 * 0464 * 0503 * 0559 \\
* 0560\end{array}$ \\
\hline Octylphenol & $* 0196$ \\
\hline Oncogenic & $* 0129 * 0155 * 0430 * 0431$ \\
\hline Optical & $* 0339 * 0340 * 0532$ \\
\hline Organic & $* 0095 * 0103 * 0167 * 0289 * 0319 * 0459 * 0471 * 0546 * 0703$ \\
\hline Organization of Work [NORA] & $* 0330 * 0331 * 0489 * 0490 * 0610$ \\
\hline Otorrinolaringol & $* 0123$ \\
\hline Ototoxic & $* 0053 * 0193$ \\
\hline Ovalbumin & $* 0003 * 0329$ \\
\hline Overhead Powerlines & $* 0415$ \\
\hline Oxidative & $* 0249 * 0251 * 0288$ \\
\hline Oxide & $* 0215 * 0352$ \\
\hline Ozone & $* 0121 * 0414 * 0476 * 0564 a$ \\
\hline Painter & $* 0281 * 0586$ \\
\hline Particle & $\begin{array}{l}* 0002 * 0003 * 0008 * 0113 * 0147 * 0167 * 0173 * 0187 * 0312 * 0339 \\
* 0340 * 0392 \mathrm{a} * 0424 * 0433 * 0472 * 0477 * 0504 * 0506 * 0526 * 0548 \mathrm{a} \\
* 0565 * 0572\end{array}$ \\
\hline Particulate & $\begin{array}{l}* 0020 * 0164 * 0167 * 0180 * 0366 * 0459 * 0469 * 0473 * 0477 * 0566 \\
* 0591 * 0703\end{array}$ \\
\hline Partnerships & $* 0157 * 0204 * 0442 * 0632$ \\
\hline Patrol Officers & $* 0241$ \\
\hline Paving & $* 0461 * 0568 * 0577$ \\
\hline Peak Flow Meters & $* 0527$ \\
\hline Peligros Para La Salud & $* 0641 \mathrm{a} * 0642$ \\
\hline Perchloroethylene & $* 0067 * 0069 * 0081$ \\
\hline Peroxidation & $* 0251 * 0285 * 0543$ \\
\hline Pesticide & $* 0017 * 0049 * 0349 * 0521$ \\
\hline Phagocytes & $* 0418$ \\
\hline Phagocytic & $* 0551$ \\
\hline Phenolic & $* 0171 * 0191 * 0439 * 0463$ \\
\hline Phosphatidylserine & $* 0251 * 0285 * 0543$ \\
\hline Phosphorylation & $* 0118 * 0221$ \\
\hline Photokeratitis & $* 0583$ \\
\hline Plumber & $* 0658$ \\
\hline Pneumoconiosis & $* 0552$ \\
\hline Pneumonitis & $* 0590$ \\
\hline Polymorphisms & $* 0134 * 0314 * 0315$ \\
\hline Popcorn & $* 0031 * 0144 * 0328 * 0346 * 0447 * 0448 * 0619$ \\
\hline Post Traumatic Stress & $* 0578$ \\
\hline Pottery & $* 0412$ \\
\hline Pregnancy & $\begin{array}{l}* 0099 * 0101 * 0121 * 0151 * 0152 * 0196 * 0225 * 0226 * 0241 * 0288 \\
* 0303 * 0632\end{array}$ \\
\hline Press Operator & $* 0591$ \\
\hline Prevention & $* 0046 * 0273 * 0454 * 0489 * 0503 * 0519 * 0557 * 0609 * 0635$ \\
\hline Protective Clothing & $* 0343 \mathrm{a}$ \\
\hline Propeller & $* 0700$ \\
\hline Prostate & $* 0091$ \\
\hline
\end{tabular}


VIII. Keyword Index

\begin{tabular}{|c|c|}
\hline Keyword & Citation Number(s) \\
\hline Pulmonary & $\begin{array}{l}* 0003 * 0004 * 0025 * 0027 * 0028 * 0031 * 0056 * 0093 * 0097 * 0109 \\
* 0112 * 0144 * 0145 * 0154 * 0156 * 0167 * 0168 * 0174 * 0177 * 0199 \\
* 0200 * 0205 * 0210 * 0212 * 0213 * 0214 * 0216 * 0228 * 0248 * 0292 \\
* 0294 * 0295 * 0300 * 0301 * 0312 * 0318 * 0319 * 0325 * 0327 * 0328 \\
* 0334 * 0353 * 0370 * 0386 * 0388 * 0389 * 0394 * 0395 * 0405 * 0406 \\
* 0412 * 0413 * 0418 * 0446 * 0447 * 0448 * 0506 * 0550 * 0551 * 0566 \\
* 0619 * 0630\end{array}$ \\
\hline Pulp & $* 0025 * 0154 * 0414$ \\
\hline Quartz & $* 0093 * 0113 * 0392 \mathrm{a} * 0432$ \\
\hline Quinone & $* 0461$ \\
\hline Radiation & $* 0023 * 0101 * 0102 * 0124 * 0242 * 0380 * 0517 * 0583 * 0624 \mathrm{a}$ \\
\hline Radiator & $* 0066$ \\
\hline Radiological Technologists & $* 0198$ \\
\hline Rapamycin & $* 0118$ \\
\hline Rashes & $* 0034$ \\
\hline Reactive Oxygen Species & $* 0043 * 0090 * 0160 * 0215$ \\
\hline Rehabilitation & $* 0290$ \\
\hline Reproductive & $* 0152 * 0225 * 0226 * 0303 * 0588 * 0632$ \\
\hline Rescue & $* 0382 * 0662 * 0675$ \\
\hline $\begin{array}{l}\text { Research Tools and Approaches } \\
\text { [NORA] }\end{array}$ & $\begin{array}{l}* 0005 * 0006 * 0007 * 0008 * 0010 * 0013 * 0014 * 0015 * 0017 * 0020 \\
* 0023 * 0024 * 0025 * 0040 * 0041 * 0042 * 0043 * 0045 * 0047 * 0049 \\
* 0060 * 0062 * 0067 * 0068 * 0069 * 0070 * 0071 * 0076 * 0077 * 0078 \\
* 0079 * 0080 * 0081 * 0082 * 0083 * 0086 * 0087 * 0089 * 0090 * 0091 \\
* 0093 * 0094 * 0095 * 0096 * 0099 * 0102 * 0103 * 0105 * 0113 * 0116 \\
* 0118 * 0124 * 0128 * 0129 * 0133 * 0134 * 0137 * 0147 * 0148 * 0150 \\
* 0155 * 0158 * 0159 * 0160 * 0161 * 0162 * 0164 * 0166 * 0175 * 0177 \\
* 0178 * 0179 * 0180 * 0181 * 0183 * 0184 * 0185 * 0190 * 0198 * 0203 \\
* 0205 * 0207 * 0211 * 0214 * 0217 * 0221 * 0222 * 0223 * 0232 * 0236 \\
* 0240 * 0243 * 0245 * 0247 * 0256 * 0258 * 0259 * 0260 * 0261 * 0263 \\
* 0266 * 0274 * 0275 * 0276 * 0277 * 0282 * 0283 * 0287 * 0289 * 0290 \\
* 0292 * 0296 * 0302 * 0303 * 0306 * 0309 * 0311 * 0317 * 0320 * 0321 \\
* 0322 * 0323 * 0324 * 0326 * 0332 * 0336 * 0337 * 0338 * 0339 * 0340 \\
* 0341 * 0346 * 0347 * 0350 * 0351 * 0354 * 0355 * 0356 * 0357 * 0358 \\
* 0359 * 0360 * 0361 * 0362 * 0363 * 0365 * 0366 * 0368 * 0369 * 0374 \\
* 0375 * 0379 \mathrm{a} * 0387 * 0388 * 0391 * 0392 * 0392 \mathrm{a} * 0396 * 0397 * 0398 \\
* 0399 * 0402 * 0407 * 0408 * 0409 * 0410 * 0414 * 0415 * 0416 * 0417 \\
* 0428 * 0430 * 0431 * 0432 * 0433 * 0434 * 0435 * 0436 * 0437 * 0438 \\
* 0440 * 0441 * 0443 * 0445 * 0450 * 0451 * 0452 * 0453 * 0456 * 0464 \\
* 0467 * 0468 * 0469 * 0470 * 0471 * 0472 * 0473 * 0475 * 0477 * 0484 \\
* 0487 * 0488 * 0489 * 0495 * 0499 * 0500 * 0501 * 0502 * 0503 * 0514 \\
* 0518 * 0519 * 0521 * 0524 * 0525 * 0526 * 0529 * 0534 * 0535 * 0541 \\
* 0542 * 0545 * 0546 * 0547 * 0548 * 0548 \mathrm{a} * 0548 \mathrm{~b} * 0552 * 0553 * 0560 \\
* 0562 * 0563 * 0564 * 0569 * 0570 * 0571 * 0572 * 0573 * 0615 * 0616 \\
* 0617 * 0618 * 0631 * 0633 * 0638 * 0696 * 0700 * 0701 * 0703 \\
*\end{array}$ \\
\hline Respirable & $\begin{array}{l}* 0093 * 0113 * 0163 * 0164 * 0355 * 0368 * 0392 \mathrm{a} * 0502 * 0508 * 0548 \mathrm{a} \\
* 0591 * 0620\end{array}$ \\
\hline Respirator & $\begin{array}{ll}* 0045 * 0341 * 0350 * 0374 * 0449 * 0453 * 0469 * 0471 * 0482 * 0541 \\
* 0573 * 0605 & \\
\end{array}$ \\
\hline
\end{tabular}


VIII. Keyword Index

\begin{tabular}{|c|c|}
\hline Keyword & Citation Number(s) \\
\hline Respiratory & $\begin{array}{l}* 0035 * 0038 * 0161 * 0258 * 0296 * 0325 * 0344 * 0374 * 0407 * 0446 \\
* 0448 * 0480 * 0481 * 0483 * 0497 * 0516 * 0569 * 0570 * 0571 * 0587 \\
* 0591 * 0597 * 0608\end{array}$ \\
\hline Retrofit & $* 0069 * 0081 * 0184 * 0355$ \\
\hline Rhinitis & $* 0414$ \\
\hline Risk Assessment & $* 0174 * 0182 * 0190 * 0230 * 0266 * 0464$ \\
\hline Risk Assessment Methods [NORA] & $\begin{array}{l}* 0093 * 0147 * 0148 * 0190 * 0205 * 0207 * 0266 * 0282 * 0283 * 0287 \\
* 0302 * 0317 * 0379 a * 0467 * 0525 * 0552 * 0638\end{array}$ \\
\hline Rollover & $* 0661 * 0689$ \\
\hline Roof & $* 0342 * 0396 * 0465 * 0466 * 0468 * 0510 * 0532 * 0648 * 0663$ \\
\hline $\begin{array}{l}\text { Roll Over Protection System } \\
\text { (ROPS) }\end{array}$ & $* 0079 * 0080 * 0217$ \\
\hline Rotameter & $* 0416$ \\
\hline Rubber Hydrochloride & $* 0253$ \\
\hline Saws & $* 0367$ \\
\hline Scaffold-end-frame & $* 0050$ \\
\hline School & $* 0034 * 0602$ \\
\hline Seismic Retrofitting & $* 0184$ \\
\hline Self-rescuer & $* 0542 * 0618$ \\
\hline Shipyard & $* 0309$ \\
\hline Short Circuits & $* 0311$ \\
\hline Silica & $\begin{array}{l}0006 * 0028 * 0058 * 0070 * 0071 * 0174 * 0175 * 0205 * 0208 * 0212 \\
* 0213 * 0215 * 0216 * 0245 * 0270 * 0283 * 0348 * 0352 * 0353 * 0356 \\
* 0357 * 0360 * 0369 * 0373 * 0396 * 0402 * 0418 * 0438 * 0507 * 0508 \\
* 0509 * 0526 * 0544 * 0548 \mathrm{a} * 0548 \mathrm{~b} * 0620\end{array}$ \\
\hline Silicosis & $\begin{array}{l}* 0174 * 0182 * 0205 * 0315 * 0353 * 0357 * 0373 * 0399 * 0412 * 0432 \\
* 0438 * 0508 * 0509 * 0544 * 0548 \mathrm{a} * 0548 \mathrm{~b} * 0602 \\
\end{array}$ \\
\hline Sinus & $* 0591$ \\
\hline Skin & $\begin{array}{l}* 0051 * 0086 * 0188 * 0249 * 0318 * 343 a * 0379 * 0407 * 0545 * 0546 \\
* 0564 * 0596\end{array}$ \\
\hline Small Business & $* 0581 * 0636$ \\
\hline Snake & $* 0280$ \\
\hline Solvent & $* 0226 * 0582 * 0587 * 0588$ \\
\hline $\begin{array}{l}\text { Special Populations at Risk } \\
\text { [NORA] }\end{array}$ & $\begin{array}{l}* 0012 * 0121 * 0163 * 0204 * 0209 * 0231 * 0403 * 0491 * 0505 * 0529 \\
* 0616 * 0639\end{array}$ \\
\hline Spectrometry & $* 0103 * 0316 * 0452$ \\
\hline Spectroscopy & $* 0159 * 0245$ \\
\hline Spine & $* 0052 * 0371$ \\
\hline Spray Booths & $* 0580$ \\
\hline Steel & $* 0484 * 0569 * 0592$ \\
\hline Stoddard Solvent & $* 0587$ \\
\hline Stone & $* 0389 * 0397 * 0422 * 0440 * 0461 * 0531 * 0549 * 0568 * 0700 * 0701$ \\
\hline Stoppings & $* 0638 * 0701$ \\
\hline Styrene & $* 0193 * 0194$ \\
\hline Supermarket & $* 0665$ \\
\hline Surveillance & $* 0019 * 0036 * 0201 * 0349 * 0386 * 0394 * 0559 a * 0609$ \\
\hline $\begin{array}{l}\text { Surveillance Research Methods } \\
\text { [NORA] }\end{array}$ & $* 0006 * 0521 * 0615$ \\
\hline
\end{tabular}


VIII. Keyword Index

\begin{tabular}{|c|c|}
\hline Keyword & Citation Number(s) \\
\hline Tanker & $* 0661 * 0676 * 0679 * 0686$ \\
\hline Teachers & $* 0303$ \\
\hline Ternary Diagram & $* 0190$ \\
\hline Terror & $* 0107 * 0481$ \\
\hline Tertiary Amines & $* 0202 * 0589$ \\
\hline Test Methods & $* 0005$ \\
\hline Tetrachloroethylene & $* 0436$ \\
\hline Thiol & $* 0003 * 0329$ \\
\hline Thoracic & $* 0178 * 0328 * 0395 * 0405 * 0406 * 0414 * 0447 * 0518 * 0552$ \\
\hline Throat Irritation & *0596 \\
\hline Tin & $* 0246 * 0364 * 0412 * 0417$ \\
\hline Titanium & $* 0478$ \\
\hline Toluene & $* 0051 * 0053 * 0176 * 0587$ \\
\hline Toxic & $* 0009 * 0043 * 0097 * 0192 * 0214 * 0282 * 0349 * 0411 * 0493 * 0582$ \\
\hline Toxicology & $* 0191 * 0192 * 0213 * 0248 * 0249 * 0349$ \\
\hline Trachea & $* 0239 * 0384 * 0385 * 0444 * 0561 * 0564 a$ \\
\hline Tractor & $* 0105 * 0647$ \\
\hline Training & $\begin{array}{l}* 0200 * 0382 * 0445 * 0457 * 0464 * 0494 * 0503 * 0529 * 0540 * 0559 \\
* 0560 * 0634 * 0661 * 0672 * 0678 * 0691 * 0695 * 0697\end{array}$ \\
\hline Traumatic & $* 0298 * 0578 * 0604$ \\
\hline Traumatic Injuries [NORA] & $\begin{array}{l}* 0013 * 0073 * 0075 * 0079 * 0080 * 0106 * 0119 * 0217 * 0240 * 0363 \\
* 0383 * 0415 * 0421 * 0422 * 0475 * 0495 * 0522\end{array}$ \\
\hline Trimethylbenzene & $* 0587$ \\
\hline Truck & $* 0234 * 0659 * 0679 * 0686$ \\
\hline Tuberculosis & $* 0335$ \\
\hline Tumor & $* 0166 * 0171 * 0176 * 0298 * 0381$ \\
\hline Tungsten & $* 0412$ \\
\hline Underground & $\begin{array}{l}* 0161 * 0240 * 0296 * 0360 * 0397 * 0422 * 0440 * 0465 * 0473 * 0505 \\
* 0530 * 0532 * 0537 * 0576 * 0633 * 0638 * 0701\end{array}$ \\
\hline Urinary & $* 0063 * 0225 * 0443$ \\
\hline Vanadate & $* 0090 * 0320 * 0321 * 0322$ \\
\hline Vanadium & $* 0295 * 0550$ \\
\hline Vascular & $* 0090 * 0091 * 0358$ \\
\hline Ventilation & $\begin{array}{l}* 0022 * 0076 * 0083 * 0309 * 0366 * 0368 * 0378 * 0390 * 0393 * 0397 \\
* 0398 * 0440 * 0441 * 0470 * 0473 * 0502 * 0534 * 0535 * 0548 * 0580 \\
* 0581 * 0638 * 0700\end{array}$ \\
\hline Vermiculite & $* 0409$ \\
\hline Vibration & $\begin{array}{l}* 0062 * 0223 * 0299 * 0347 * 0358 * 0375 * 0388 * 0456 * 0532 * 0540 \\
* 0579\end{array}$ \\
\hline Virus & $* 0046 * 0104$ \\
\hline Vision & $* 0589$ \\
\hline Warning System & $* 0622 \mathrm{a}$ \\
\hline Welders & $* 0269$ \\
\hline Welding & $* 0290 * 0309 * 0323 * 0324 * 0536$ \\
\hline Women & $* 0225 * 0226 * 0231 * 0330$ \\
\hline
\end{tabular}


VIII. Keyword Index

\begin{tabular}{|l|l|}
\hline \multicolumn{1}{|c|}{ Keyword } & \multicolumn{1}{|c|}{ Citation Number(s) } \\
\hline Work Environment and Workforce & $* 0002 * 0003 * 0004 * 0012 * 0027 * 0097 * 0108 * 0113 * 0120 * 0121$ \\
[NORA] & $* 0133 * 0163 * 0167 * 0168 * 0186 * 0187 * 0204 * 0209 * 0231 * 0252$ \\
& $* 0294 * 0295 * 0310 * 0312 * 0313 * 0325 * 0329 * 0330 * 0331 * 0378$ \\
& $* 0388 * 0389 * 0390 * 0392 \mathrm{a} * 0403 * 0419 * 0420 * 0432 * 0433 * 0461$ \\
& $* 0477 * 0485 * 0489 * 0490 * 0491 * 0497 * 0498 * 0504 * 0505 * 0506$ \\
& $* 0512 * 0513 * 0516 * 0529 * 0536 * 0544 * 0548 \mathrm{a} * 0549 * 0550 * 0555$ \\
& $* 0565 * 0566 * 0568 * 0597 * 0598 * 0610 * 0616 * 0639 * 0703$ \\
\hline Workers & $* 0039 * 0051 * 0607$ \\
\hline World Trade Center & $* 0029 * 0038 * 0578 * 0627 \mathrm{a}$ \\
\hline Wrist & $* 0057$ \\
\hline & \\
\hline Youth & $* 0110$ \\
\hline
\end{tabular}




\section{NATIONAL OCCUPATIONAL RESEARCH AGENDA (NORA) INDEX}

\begin{tabular}{|c|c|}
\hline Topic & Citation Number(s) \\
\hline \multicolumn{2}{|l|}{ Disease and Injury } \\
\hline Allergic and Irritant Dermatitis & $* 0051 * 0130 * 0191 * 0246 * 0248 * 0249 * 0250 * 0251 * 0316 * 0545 * 0546$ \\
\hline $\begin{array}{l}\text { Asthma and Chronic Obstructive } \\
\text { Pulmonary Disease }\end{array}$ & $\begin{array}{l}* 0025 * 0031 * 0056 * 0109 * 0112 * 0144 * 0145 * 0154 * 0156 * 0174 * 0199 \\
* 0200 * 0205 * 0210 * 0300 * 0301 * 0318 * 0319 * 0325 * 0327 * 0328 * 0334 \\
* 0370 * 0386 * 0389 * 0394 * 0395 * 0405 * 0406 * 0412 * 0413 * 0446 * 0447 \\
* 0448 * 0619 * 0630\end{array}$ \\
\hline $\begin{array}{l}\text { Fertility and Pregnancy } \\
\text { Abnormalities }\end{array}$ & $\begin{array}{l}* 0099 * 0101 * 0121 * 0151 * 0152 * 0196 * 0225 * 0226 * 0241 * 0288 * 0303 \\
* 0632\end{array}$ \\
\hline Hearing Loss & $\begin{array}{l}* 0054 * 0123 * 0143 * 0192 * 0193 * 0194 * 0195 * 0197 * 0218 * 0219 * 0220 \\
* 0279 * 0529\end{array}$ \\
\hline Infectious Diseases & $* 0046 * 0238 * 0239 * 0335 * 0428 \mathrm{a} * 0585 * 0639$ \\
\hline Low Back Disorders & $* 0089 * 0391 * 0547 * 0553$ \\
\hline Musculoskeletal Disorders & $\begin{array}{l}* 0052 * 0057 * 0062 * 0073 * 0074 * 0075 * 0084 * 0088 * 0223 * 0261 * 0299 \\
* 0306 * 0326 * 0358 * 0371 * 0375 * 0400 * 0429 * 0456 * 0562 * 0563 * 0564\end{array}$ \\
\hline Traumatic Injuries & $\begin{array}{l}* 0013 * 0073 * 0075 * 0079 * 0080 * 0106 * 0119 * 0217 * 0240 * 0363 * 0383 \\
* 0415 * 0421 * 0422 * 0475 * 0495 * 0522 \\
\end{array}$ \\
\hline \multicolumn{2}{|c|}{ Research Tools and Approaches } \\
\hline Cancer Research Methods & $\begin{array}{l}* 0040 * 0041 * 0042 * 0043 * 0060 * 0090 * 0091 * 0118 * 0128 * 0129 * 0134 \\
* 0155 * 0158 * 0159 * 0160 * 0162 * 0166 * 0221 * 0263 * 0320 * 0321 * 0322 \\
* 0351 * 0362 * 0402 * 0430 * 0431 * 0434 * 0435 * 0436 * 0500 * 0501 * 0519\end{array}$ \\
\hline $\begin{array}{l}\text { Control Technology and Personal } \\
\text { Protective Equipment }\end{array}$ & $\begin{array}{l}* 0045 * 0047 * 0062 * 0067 * 0068 * 0069 * 0070 * 0071 * 0076 * 0077 * 0078 \\
* 0079 * 0080 * 0081 * 0082 * 0083 * 0116 * 0124 * 0161 * 0185 * 0203 * 0217 \\
* 0222 * 0223 * 0232 * 0258 * 0261 * 0276 * 0289 * 0290 * 0296 * 0306 * 0309 \\
* 0311 * 0323 * 0324 * 0326 * 0336 * 0337 * 0339 * 0340 * 0341 * 0346 * 0347 \\
* 0350 * 0354 * 0355 * 0356 * 0357 * 0358 * 0359 * 0360 * 0363 * 0365 * 0366 \\
* 0368 * 0369 * 0374 * 0375 * 0391 * 0392 * 0396 * 0397 * 0398 * 0415 * 0428 \\
* 0445 * 0453 * 0464 * 0467 * 0468 * 0469 * 0470 * 0471 * 0475 * 0484 * 0487 \\
* 0488 * 0495 * 0503 * 0514 * 0534 * 0535 * 0541 * 0542 * 0545 * 0546 * 0547 \\
* 0560 * 0562 * 0563 * 0564 * 0569 * 0570 * 0571 * 0573 * 0618 * 0631 * 0633 \\
* 0638 * 0700 * 0701\end{array}$ \\
\hline Exposure Assessment Methods & $\begin{array}{l}* 0005 * 0007 * 0008 * 0010 * 0014 * 0015 * 0017 * 0020 * 0023 * 0024 * 0025 \\
* 0049 * 0086 * 0087 * 0094 * 0095 * 0096 * 0099 * 0102 * 0103 * 0105 * 0113 \\
* 0133 * 0137 * 0150 * 0164 * 0175 * 0177 * 0178 * 0179 * 0180 * 0181 * 0183 \\
* 0184 * 0198 * 0211 * 0236 * 0243 * 0245 * 0247 * 0259 * 0260 * 0274 * 0275 \\
* 0277 * 0292 * 0303 * 0332 * 0338 * 0361 * 0387 * 0388 * 0392 \mathrm{a} * 0399 \\
* 0407 * 0408 * 0409 * 0410 * 0414 * 0416 * 0417 * 0432 * 0433 * 0437 * 0438 \\
* 0440 * 0441 * 0443 * 0450 * 0451 * 0452 * 0456 * 0472 * 0473 * 0477 * 0499 \\
* 0502 * 0518 * 0524 * 0526 * 0548 * 0548 \mathrm{a} * 0548 \mathrm{~b} * 0572 * 0617 * 0633 \\
* 0703\end{array}$ \\
\hline Intervention Effectiveness Research & $\begin{array}{l}* 0013 * 0067 * 0068 * 0069 * 0070 * 0071 * 0081 * 0089 * 0214 * 0232 * 0240 \\
* 0256 * 0290 * 0309 * 0489 * 0529 * 0553 * 0616 * 0696\end{array}$ \\
\hline Risk Assessment Methods & $\begin{array}{l}* 0093 * 0147 * 0148 * 0190 * 0205 * 0207 * 0266 * 0282 * 0283 * 0287 * 0302 \\
* 0317 * 0379 \mathrm{a} * 0467 * 0525 * 0552 * 0638\end{array}$ \\
\hline Surveillance Research Methods & $* 0006 * 0521 * 0615$ \\
\hline
\end{tabular}


IX. National Occupational Research Agenda (NORA) Index

\begin{tabular}{|l|l|}
\hline \multicolumn{1}{|c|}{ Topic } & \multicolumn{1}{c|}{ Citation Number(s) } \\
\hline Work Environment and Workforce & \multicolumn{1}{c|}{} \\
\hline Emerging Technologies & $* 0378 * 0390 * 0485 * 0512 * 0513 * 0699$ \\
\hline Indoor Environment & $* 0186 * 0187 * 0252 * 0437 * 0447 \mathrm{a} * 0497 * 0498 * 0504 * 0516 * 0555$ \\
& $* 0578 * 0585 * 0596 * 0597 * 0598$ \\
\hline Mixed Exposures & $* 0002 * 0003 * 0004 * 0027 * 0097 * 0108 * 0113 * 0120 * 0133 * 0167 * 0168$ \\
& $* 0294 * 0295 * 0310 * 0312 * 0313 * 0325 * 0329 * 0388 * 0389 * 0392 \mathrm{a}$ \\
& $* 0419 * 0420 * 0432 * 0433 * 0461 * 0477 * 0506 * 0536 * 0544 * 0548 \mathrm{a}$ \\
\hline Organization of Work & $* 0549 * 0550 * 0565 * 0566 * 0568 * 0703$ \\
\hline Special Populations at Risk & $* 0330 * 0331 * 0489 * 0490 * 0610$ \\
\hline & $* 0012 * 0121 * 0163 * 0204 * 0209 * 0231 * 0403 * 0491 * 0505 * 0529 * 0616$ \\
\hline
\end{tabular}




\section{AUTHOR INDEX}

\begin{tabular}{|c|c|}
\hline Author & Citation Number(s) \\
\hline Abbott R & $* 0209$ \\
\hline Afshari A & $* 0325 * 0326 * 0388 * 0389 * 0531$ \\
\hline Aguilar-Madrid G & *0066 \\
\hline Ahlers H & *0399 \\
\hline Aizenberg V & $* 0009$ \\
\hline Akpinar-Elci M & $* 0327 * 0328 * 0379 a$ \\
\hline Al-Humadi N & $* 0002 * 0003 * 0329$ \\
\hline Alavanja M & *0049 \\
\hline Alexander D & *0186 \\
\hline Alterman T & $* 0330 * 0331$ \\
\hline Alvarenga $\mathrm{K}$ & $* 0123$ \\
\hline Ambrose D & *0547 \\
\hline Ammons D & $* 0522$ \\
\hline Andersen A & *0154 \\
\hline Andersen M & $* 0282 * 0317$ \\
\hline Anderson A & $* 0025$ \\
\hline Anderson C & $* 0233$ \\
\hline Anderson $\mathbf{S}$ & *0149 \\
\hline Andrews G & $* 0411$ \\
\hline Antonini J & $* 0004 * 0091 * 0278 * 0294 * 0312 * 0478 * 0479 * 0536 * 0551 * 0565$ \\
\hline Arch B & *0186 \\
\hline Arena V & *0149 \\
\hline Aro A & $* 0099$ \\
\hline Ashley J & *0355 \\
\hline Ashley K & $* 0005 * 0275 * 0277 * 0332$ \\
\hline Attfield M & $* 0006 * 0174 * 0175 * 0270 * 0412 * 0446 * 0447 \mathrm{a} * 0497 * 0516 * 0526$ \\
\hline Azadi S & $* 0325$ \\
\hline Bailer A & $* 0147 * 0207 * 0317$ \\
\hline Baisden J & *0221 \\
\hline Bajpayee T & $* 0333$ \\
\hline Baldwin K & $* 0170$ \\
\hline Bang K & $* 0112 * 0334 * 0335 * 0413$ \\
\hline Banks D & $* 0200$ \\
\hline Barczak T & $* 0336 * 0337$ \\
\hline Barger $\mathbf{M}$ & $\begin{array}{l}* 0002 * 0003 * 0097 * 0168 * 0212 * 0213 * 0214 * 0216 * 0310 * 0312 * 0313 * 0329 \\
* 0418 * 0461 * 0506 * 0565 * 0566 * 0568\end{array}$ \\
\hline Barkley J & *0389 \\
\hline Barnett M & *0349 \\
\hline Baron P & $* 0007 * 0008 * 0009 * 0010 * 0094 * 0172 * 0173 * 0324$ \\
\hline Baron S & $* 0026 * 0073$ \\
\hline Barthalmus G & $* 0280$ \\
\hline Bartlett K & *0044 \\
\hline Bartley D & $* 0011 * 0338$ \\
\hline Barton T & $* 0468 * 0496$ \\
\hline
\end{tabular}




\begin{tabular}{|c|c|}
\hline Author & Citation Number(s) \\
\hline$\overline{\text { Bates A }}$ & $* 0085$ \\
\hline Battelli L & $* 0097 * 0120 * 0140 * 0214 * 0292 * 0419 * 0420 * 0461 * 0548 \mathrm{~b}$ \\
\hline Bayard S & $* 0317$ \\
\hline Beaton S & $* 0417$ \\
\hline Becker E & $* 0050$ \\
\hline Beeckman-Wagner L & $* 0012$ \\
\hline Belkin H & $* 0085$ \\
\hline Bell B & $* 0428 \mathrm{a}$ \\
\hline Bell D & $* 0351$ \\
\hline Bell J & $* 0013$ \\
\hline Bellinger D & $* 0099$ \\
\hline Bello D & $* 0014 * 0015$ \\
\hline Benkovic S & $* 0264 * 0265 * 0486$ \\
\hline Bennett J & $* 0008 * 0082 * 0083$ \\
\hline Berakis M & $* 0243 * 0472 * 0518$ \\
\hline Berardinelli S & $* 0339 * 0340 * 0341 * 0366 * 0428 * 0470 * 0572$ \\
\hline Bergeret A & $* 0025 * 0154$ \\
\hline Berry A & $* 0483 * 0570$ \\
\hline Beus M & *0016 \\
\hline Biagini R & $* 0017$ \\
\hline Biddle E & $* 0018 * 0019 * 0403$ \\
\hline Birch M & $* 0020$ \\
\hline Bird A & $* 0260$ \\
\hline Bishop H & $* 0292 * 0548 b$ \\
\hline Biswas P & $* 0324$ \\
\hline Blade L & $* 0309$ \\
\hline Blair A & $* 0379 \mathrm{a} * 0519$ \\
\hline Blake W & $* 0558$ \\
\hline Blanchette P & $* 0209$ \\
\hline Blanciforti L & $* 0423$ \\
\hline Bledsoe T & $* 0108 * 0372$ \\
\hline Blemings K & $* 0431 \mathrm{a}$ \\
\hline Blondell J & $* 0349$ \\
\hline Bloom T & $* 0102 * 0555$ \\
\hline Boal W & $* 0104$ \\
\hline Bobick T & $* 0342$ \\
\hline Bockosh G & $* 0343$ \\
\hline Boeniger M & $* 0021 * 0139 * 0187 * 0343 a$ \\
\hline Boffetta P & $* 0025 * 0174$ \\
\hline Bogdanffy M & $* 0282$ \\
\hline Boiano J & $* 0184$ \\
\hline Boileau P & $* 0223$ \\
\hline Boissy R & $* 0351$ \\
\hline Boland G & $* 0314$ \\
\hline Bonassi S & $* 0519$ \\
\hline Boord L & $* 0344$ \\
\hline Booth-Butterfield S & $* 0345$ \\
\hline Bower J & $* 0040 * 0362$ \\
\hline Bowman J & *0183 \\
\hline
\end{tabular}




\begin{tabular}{|c|c|}
\hline Author & Citation Number(s) \\
\hline Bowman L & $* 0224 * 0373$ \\
\hline Boyett K & $* 0100$ \\
\hline Boylstein R & $* 0346 * 0448$ \\
\hline Brady T & $* 0567$ \\
\hline Brandt-Rauf P & $* 0519$ \\
\hline Brautigam A & $* 0311$ \\
\hline Brechner R & $* 0428 \mathrm{a}$ \\
\hline Breitenstein M & $* 0241$ \\
\hline Bresnitz E & $* 0428 \mathrm{a}$ \\
\hline Breysse P & $* 0183$ \\
\hline Bridges J & $* 0236$ \\
\hline Brnich M & $* 0445 * 0464$ \\
\hline Broyles L & $* 0372 \mathrm{a}$ \\
\hline Brumbaugh $\mathrm{K}$ & $* 0121$ \\
\hline Bugarski A & $* 0473$ \\
\hline Buncher C & $* 0024$ \\
\hline Buncher R & $* 0023$ \\
\hline Burdette $\mathbf{H}$ & $* 0463$ \\
\hline Burnett C & $* 0153$ \\
\hline Burr G & $* 0281$ \\
\hline Burroughs G & $* 0226$ \\
\hline Burton N & $* 0022$ \\
\hline Butler J & $* 0428 \mathrm{a}$ \\
\hline Butler M & $* 0524$ \\
\hline Byrne D & $* 0347 * 0484$ \\
\hline Cain W & $* 0186$ \\
\hline Calhoun $\mathbf{R}$ & $* 0503 * 0559$ \\
\hline Calvert C & $* 0365 * 0366 * 0470$ \\
\hline Calvert G & $* 0348 * 0349$ \\
\hline Cameron L & $* 0153$ \\
\hline Campbell D & $* 0045 * 0350 * 0365 * 0453$ \\
\hline Campo P & $* 0193 * 0218 * 0219$ \\
\hline Cardarelli J & $* 0023 * 0024 * 0198$ \\
\hline Carel R & $* 0025$ \\
\hline Carreón T & $* 0351 * 0026$ \\
\hline Carte D & $* 0200$ \\
\hline Cartter M & $* 0559 \mathrm{a}$ \\
\hline Cassinelli M & $* 0274$ \\
\hline Castellan R & $* 0552$ \\
\hline Castranova V & $\begin{array}{l}* 0009 * 0027 * 0028 * 0040 * 0059 * 0085 * 0091 * 0097 * 0118 * 0120 * 0158 * 0159 \\
* 0160 * 0162 * 0168 * 0212 * 0213 * 0214 * 0215 * 0216 * 0248 * 0249 * 0250 * 0251 \\
* 0283 * 0294 * 0295 * 0313 * 0352 * 0353 * 0362 * 0373 * 0399 * 0419 * 0420 * 0461 \\
* 0478 * 0479 * 0506 * 0550 * 0551 * 0566 * 0568\end{array}$ \\
\hline Catlett L & $* 0521$ \\
\hline Cawley J & $* 0311 * 0354 * 0415$ \\
\hline CDC & $* 0029 * 0030 * 0031 * 0032 * 0033 * 0034 * 0035 * 0036 * 0037 * 0038 * 0039$ \\
\hline Cecala A & $* 0355 * 0356 * 0357$ \\
\hline Cetron M & $* 0428 \mathrm{a}$ \\
\hline Cezeaux J & $* 0358$ \\
\hline
\end{tabular}




\begin{tabular}{|c|c|}
\hline Author & Citation Number(s) \\
\hline Chapman L & $* 0046$ \\
\hline Chase F & $* 0359 * 0467$ \\
\hline Chasko L & $* 0047$ \\
\hline Checkoway H & $* 0006 * 0174 * 0175 * 0205$ \\
\hline Chekan G & $* 0360 * 0368$ \\
\hline Chen B & $* 0094 * 0095 * 0245 * 0361 * 0437 * 0452$ \\
\hline Chen C & $* 0317$ \\
\hline Chen F & $* 0040 * 0041 * 0042 * 0043 * 0058 * 0166 * 0320 * 0321 * 0362$ \\
\hline Chen I & $* 0412$ \\
\hline Chen J & $* 0006 * 0175 * 0548 \mathrm{a} * 0567$ \\
\hline Chen W & $* 0412 * 0548 \mathrm{a}$ \\
\hline Chen X & $* 0330$ \\
\hline Cheng J & $* 0194$ \\
\hline Cherezova L & $* 0221$ \\
\hline Chew V & $* 0044$ \\
\hline Chilton J & $* 0534$ \\
\hline Chiou S & $* 0363$ \\
\hline Chisholm W & $* 0548 \mathrm{a}$ \\
\hline Christiani D & $* 0108$ \\
\hline Chun D & $* 0044$ \\
\hline Clark C & $* 0530$ \\
\hline Clark J & $* 0241 * 0443 * 0524$ \\
\hline Clarke R & $* 0004$ \\
\hline Clerval C & $* 0364$ \\
\hline Clewell H & $* 0317$ \\
\hline Cocalis J & $* 0505$ \\
\hline Coffey C & $* 0045 * 0341 * 0350 * 0365 * 0366 * 0453 * 0470 * 0572 * 0573$ \\
\hline Coggon D & $* 0025$ \\
\hline Cohen J & $* 0046$ \\
\hline Cohen P & $* 0208$ \\
\hline Coleman A & $* 0237$ \\
\hline Coleman P & $* 0367$ \\
\hline Colin D & $* 0154$ \\
\hline Colinet J & $* 0357 * 0360 * 0368 * 0369$ \\
\hline Colligan M & $* 0297$ \\
\hline Collins R & $* 0281$ \\
\hline Commodore $\mathrm{M}$ & $* 0487 * 0488$ \\
\hline Compton C & $* 0466$ \\
\hline Connaughton I & $* 0229$ \\
\hline Connor K & $* 0100$ \\
\hline Conolly R & $* 0317$ \\
\hline Conover D & $* 0101 * 0336$ \\
\hline Conti R & $* 0047$ \\
\hline Conway $\mathbf{G}$ & $* 0048$ \\
\hline Cook C & $* 0202$ \\
\hline Cooper G & $* 0208$ \\
\hline Cooper S & $* 0253$ \\
\hline Corum L & $* 0091$ \\
\hline Costa M & $* 0059 * 0118$ \\
\hline
\end{tabular}




\begin{tabular}{|c|c|}
\hline Author & Citation Number(s) \\
\hline $\operatorname{Cox} \mathrm{C}$ & $* 0101$ \\
\hline Cox-Ganser J & $* 0370 * 0497 * 0504$ \\
\hline Coyle P & $* 0421$ \\
\hline Crandall M & $* 0252$ \\
\hline Croteau E & $* 0229$ \\
\hline Crump K & $* 0317$ \\
\hline $\operatorname{Cseh} \mathrm{L}$ & $* 0281$ \\
\hline Cui M & $* 0459 * 0477 * 0703$ \\
\hline Curwin B & $* 0049 * 0236$ \\
\hline Cutler D & $* 0158$ \\
\hline Cutlip R & $* 0050 * 0079 * 0080 * 0401$ \\
\hline Daftarian H & $* 0051$ \\
\hline Daniels R & $* 0024$ \\
\hline Dankovic D & $*^{*} 0147 * 0282$ \\
\hline$\overline{\text { Daroowalla F }}$ & $* 0446$ \\
\hline Daston G & $* 0152$ \\
\hline Davenport D & $* 0046$ \\
\hline Davis K & $* 0052 * 0084 * 0089 * 0371 * 0391$ \\
\hline Davis L & $* 0386 * 0405 * 0406$ \\
\hline Davis R & $* 0053 * 0054 * 0143$ \\
\hline Day B & $* 0374$ \\
\hline De Feo A & $* 0364$ \\
\hline de la Rosa P & $* 0565$ \\
\hline Deddens J & $* 0187 * 0271 * 0555$ \\
\hline DeHaven J & $* 0316$ \\
\hline Deitchman S & $* 0046$ \\
\hline DeKlerk N & $* 0006 * 0174 * 0175$ \\
\hline Delaney L & $* 0135 * 0184$ \\
\hline Demchuk E & $* 0257 * 0523$ \\
\hline Dement J & $* 0208$ \\
\hline Demers L & $* 0041$ \\
\hline Denison M & $* 0463$ \\
\hline Depree G & $* 0372$ \\
\hline Derk R & $* 0196$ \\
\hline Derk S & $* 0405$ \\
\hline Deubner D & $* 0243 * 0407 * 0518$ \\
\hline Dewan P & $* 0372 \mathrm{a}$ \\
\hline deWit H & $* 0227$ \\
\hline Dey R & $* 0027 * 0307 * 0564 a$ \\
\hline Deye G & $* 0009$ \\
\hline Diamond W & ${ }_{* 0393}^{*}$ \\
\hline DiCarlo G & $* 0100$ \\
\hline Dillard S & $* 0056 * 0211$ \\
\hline Dillon C & $* 0057$ \\
\hline Ding M & $* 0040 * 0058 * 0059 * 0060 * 0090 * 0121 * 0158 * 0295 * 0362 * 0373$ \\
\hline Dobroski H & $* 0061$ \\
\hline Dolinar D & $*^{*} 0422 * 0466$ \\
\hline Doney B & $* 0374 * 0408$ \\
\hline
\end{tabular}




\begin{tabular}{|c|c|}
\hline Author & Citation Number(s) \\
\hline$\overline{\text { Dong C }}$ & $* 0565$ \\
\hline Dong M & $* 0187$ \\
\hline Dong R & $* 0062 * 0222 * 0223 * 0261 * 0306 * 0375 * 0562 * 0563 * 0564$ \\
\hline Donham K & $* 0229$ \\
\hline Dooley M & $* 0208$ \\
\hline Dosemeci M & $* 0006 * 0175 * 0379 \mathrm{a}$ \\
\hline Dotson B & $* 0522$ \\
\hline Douwes J & $* 0229$ \\
\hline Dowdy J & $* 0120 * 0384$ \\
\hline Dower J & *0344 \\
\hline Doyle T & $* 0428 \mathrm{a}$ \\
\hline Drake P & $* 0063 * 0376 * 0377$ \\
\hline Driscoll T & *0064 \\
\hline Ducatman A & $* 0161 * 0296$ \\
\hline Dunford J & $* 0567$ \\
\hline Dunn K & $* 0068$ \\
\hline Dunson D & $* 0317$ \\
\hline Durkin M & $* 0065$ \\
\hline Dykeman $\mathbf{R}$ & $* 0066$ \\
\hline Earnest G & $* 0067 * 0068 * 0069 * 0081 * 0284$ \\
\hline Ebeling T & $* 0228$ \\
\hline Echt A & $* 0070 * 0071 * 0232$ \\
\hline Edwards J & $* 0378 * 0390$ \\
\hline Edwards R & $* 0101$ \\
\hline Ehlers J & *0204 \\
\hline Eisen $\mathbf{E}$ & $* 0108$ \\
\hline Eisold J & $* 0417 \mathrm{a}$ \\
\hline El-Ayouby N & $* 0379$ \\
\hline El-Fawal H & $* 0364$ \\
\hline Elci O & $* 0327 * 0379 \mathrm{a}$ \\
\hline Elie C & $* 0372 a * 0417 a$ \\
\hline Ellenberger J & $* 0404$ \\
\hline Elliott L & $* 0380 * 0517$ \\
\hline Elson $\mathbf{H}$ & $* 0023 * 0024$ \\
\hline Enright P & $* 0144 * 0145 * 0447$ \\
\hline Ensell M & $* 0381 * 0459 * 0515 * 0703$ \\
\hline Ensey J & $* 0302$ \\
\hline Eppley D & $* 0382$ \\
\hline Ernstgard L & $*_{00194}$ \\
\hline Erway L & $*_{0143}$ \\
\hline Eschenbacher W & $* 0258$ \\
\hline Estill C & $* 0073 * 0074 * 0075 * 0076 * 0077 * 0078$ \\
\hline Etherton J & $* 0079 * 0080 * 0217 * 0383 * 0475$ \\
\hline Ewers L & $* 0069 * 0081$ \\
\hline Fabisiak J & $* 0251 * 0285$ \\
\hline Facchini L & $* 0025 * 0154$ \\
\hline Faulkner D & $* 0187$ \\
\hline
\end{tabular}




\begin{tabular}{|c|c|}
\hline Author & Citation Number(s) \\
\hline Faustman E & $* 0282$ \\
\hline Fechter L & $* 0218 * 0219$ \\
\hline Fedan J & $* 0120 * 0307 * 0384 * 0385 * 0444 * 0561 * 0564 a$ \\
\hline Fedan K & $* 0144 * 0145 * 0447$ \\
\hline Feigley C & $* 0082 * 0083$ \\
\hline Felschow D & $* 0493$ \\
\hline Feng P & $* 0351$ \\
\hline Ferguson $\mathbf{S}$ & $* 0084$ \\
\hline Feuerstein $\mathrm{M}$ & $* 0119$ \\
\hline Feyer A & $* 0064$ \\
\hline Filios M & $* 0386 * 0394 * 0405 * 0406$ \\
\hline Finch C & $* 0233$ \\
\hline Finkel A & $* 0317$ \\
\hline Finkelman R & $* 0085$ \\
\hline Fischbach T & $* 0290$ \\
\hline Fischer M & $* 0428 \mathrm{a} * 0559 \mathrm{a}$ \\
\hline Fisher T & $* 0355$ \\
\hline Fisk W & $* 0186 * 0187$ \\
\hline Flattery J & $* 0386 * 0405 * 0406$ \\
\hline Flick J & $* 0503 * 0559$ \\
\hline Flynn D & $* 0091 * 0221 * 0501$ \\
\hline Foley D & $* 0209$ \\
\hline Foster P & $* 0282$ \\
\hline Fotta B & $* 0343$ \\
\hline Fotta F & $* 0428$ \\
\hline Fotta $\mathrm{S}$ & $* 0339 * 0340 * 0487 * 0488$ \\
\hline Franks J & $* 0194 * 0197 * 0288$ \\
\hline Franks R & $* 0378$ \\
\hline Frasch $\mathrm{H}$ & $* 0086 * 0087 * 0387$ \\
\hline Frazer D & $\begin{array}{l}* 0027 * 0120 * 0228 * 0248 * 0313 * 0325 * 0326 * 0388 * 0389 * 0420 * 0461 * 0476 \\
* 0531 * 0549 * 0566 * 0568\end{array}$ \\
\hline Frederick C & $* 0282$ \\
\hline Freed J & $* 0236$ \\
\hline French P & $* 0417$ \\
\hline Friel G & $* 0378 * 0390$ \\
\hline Friend S & $* 0120 * 0419 * 0420$ \\
\hline Fry A & $* 0372 \mathrm{a}$ \\
\hline Frye B & $* 0134$ \\
\hline Gahr S & $* 0140$ \\
\hline Galinsky T & $* 0088$ \\
\hline Gallagher S & $* 0089 * 0391 * 0392 * 0454$ \\
\hline Gao N & $* 0090 * 0091 * 0093 * 0392 \mathrm{a} * 0432$ \\
\hline Gao P & $* 0094 * 0095 * 0096 * 0379$ \\
\hline Garcia F & $* 0393 * 0397 * 0398$ \\
\hline Garcia R & $* 0050$ \\
\hline Garssen J. deGruijl F & $* 0314$ \\
\hline Gaudes-MacLaren L & $* 0084$ \\
\hline Gautam M & $* 0477$ \\
\hline Gerberich S & $* 0106$ \\
\hline
\end{tabular}




\begin{tabular}{|c|c|}
\hline Author & Citation Number(s) \\
\hline Gershon R & $* 0256$ \\
\hline Ghanem M & $* 0097$ \\
\hline Gilbert S & $* 0205 * 0207$ \\
\hline Gilkeson G & $* 0208$ \\
\hline Giraldo daSilva Augusto L & $* 0279$ \\
\hline Girard J & $* 0474 * 0494$ \\
\hline Girman J & $* 0186$ \\
\hline Glaser R & $* 0098$ \\
\hline Goe S & $* 0394 * 0395 * 0408$ \\
\hline Gold D & $* 0498$ \\
\hline Goldenhar L & $* 0081$ \\
\hline Goldsmith T & $* 0248 * 0325 * 0389 * 0476 * 0531 * 0549$ \\
\hline Goldsmith W & $* 0120 * 0419 * 0420$ \\
\hline Gomaa A & $* 0099 * 0144 * 0145 * 0447$ \\
\hline Gonzalez-Cossio T & $* 0099$ \\
\hline Goodman G & $* 0396$ \\
\hline Gordon M & $* 0100$ \\
\hline Gordon T & $* 0044$ \\
\hline Gorny R & $* 0172$ \\
\hline Grajewski B & $* 0101 * 0102 * 0152 * 0303 * 0555$ \\
\hline Grant D & $* 0351$ \\
\hline Grau R & $* 0360 * 0397 * 0398$ \\
\hline Greene C & $* 0428 \mathrm{a}$ \\
\hline Gregory E & $* 0401$ \\
\hline Grenier M & $* 0473$ \\
\hline Gresh R & $* 0355$ \\
\hline Greskevitch M & $* 0214 * 0399$ \\
\hline Gressel M & $* 0185$ \\
\hline Griffith K & $* 0428 \mathrm{a}$ \\
\hline Grinshpun S & $* 0010 * 0172 * 0173$ \\
\hline Groce D & $* 0374 * 0408$ \\
\hline Grosch J & $* 0330 * 0331 * 0403$ \\
\hline Gross T & $* 0056 * 0211$ \\
\hline Grote A & $* 0103 * 0120 * 0202$ \\
\hline Guan J & $* 0115 * 0571 * 0573$ \\
\hline Guappone-Koay A & $* 0221$ \\
\hline Guarner J & $* 0428 \mathrm{a}$ \\
\hline Gunn V & $* 0044$ \\
\hline Gunther M & $* 0250$ \\
\hline Gupta N & $* 0292 * 0548 b$ \\
\hline Gupta P & $* 0052$ \\
\hline Haber L & $* 0282 * 0317$ \\
\hline Hadler J & $* 0281 * 0428 \mathrm{a} * 0559 \mathrm{a}$ \\
\hline Haggerty $\mathbf{J}$ & $* 0503 * 0559$ \\
\hline Hajjeh R & $* 0417 \mathrm{a}$ \\
\hline Hales T & $* 0104 * 0372 \mathrm{a} * 0400 * 0417 \mathrm{a}$ \\
\hline Hall I & $* 0401$ \\
\hline Hall R & $* 0068 * 0076 * 0105 * 0284 * 0379$ \\
\hline
\end{tabular}




\begin{tabular}{|c|c|}
\hline Author & Citation Number(s) \\
\hline Halperin W & $* 0207$ \\
\hline Han B & $* 0261$ \\
\hline Handzel T & $* 0417 \mathrm{a}$ \\
\hline Hanrahan L & $* 0110$ \\
\hline Hard D & $* 0106 * 0454$ \\
\hline Harison R & $* 0386$ \\
\hline Harney J & $* 0107$ \\
\hline Harper S & $* 0417 \mathrm{a}$ \\
\hline Harris $G$ & $* 0402$ \\
\hline Harris J & $* 0079 * 0080 * 0217$ \\
\hline Harrison J & $* 0133 * 0433 * 0548 \mathrm{a}$ \\
\hline Harrison R & $* 0405 * 0406$ \\
\hline Hartley D & $* 0018 * 0403$ \\
\hline Hater M & *0202 \\
\hline Hattis D & $* 0266 * 0317 * 0525$ \\
\hline Hauser R & $* 0108$ \\
\hline Hayes J & $* 0339 * 0340 * 0428 * 0487 * 0488$ \\
\hline Hayes R & $* 0351$ \\
\hline Hayslett J & $* 0372 \mathrm{a} * 0417 \mathrm{a} * 0428 \mathrm{a}$ \\
\hline Не H & $* 0321 * 0502$ \\
\hline Heaney C & $* 0052$ \\
\hline Hearl F & $* 0399$ \\
\hline Heasley K & $* 0359 * 0404$ \\
\hline Heederik D & $* 0229$ \\
\hline Hefflin B & $* 0056 * 0211$ \\
\hline Hein M & $* 0049 * 0236$ \\
\hline Heitbrink W & $* 0105 * 0346 * 0355 * 0357$ \\
\hline Hemstreet G & $* 0351$ \\
\hline Henderson D & $* 0053$ \\
\hline Henley J & $* 0272$ \\
\hline Henneberger $\mathbf{P}$ & $* 0025 * 0109 * 0154 * 0243 * 0395 * 0405 * 0406 * 0407 * 0408 * 0414 * 0518$ \\
\hline Hernandez S & $* 0026$ \\
\hline Hernandez-Avila $\mathbf{M}$ & $* 0099 * 0066$ \\
\hline Hewett D & *0409 \\
\hline Hewett P & $* 0410 * 0572$ \\
\hline Higgins D & $* 0110$ \\
\hline Hilliard J & *0046 \\
\hline Hines C & $* 0186 * 0187$ \\
\hline Hines R & $* 0411$ \\
\hline Hinshaw G & $* 0510$ \\
\hline Hinze J & $* 0455$ \\
\hline Hipkins K & $* 0201$ \\
\hline Hnizdo E & $* 0006 * 0112 * 0175 * 0412 * 0413 * 0544 * 0548 \mathrm{a}$ \\
\hline Hnizdo V & $* 0113 * 0257 * 0523 * 0548 \mathrm{a}$ \\
\hline Hoch M & $* 0467$ \\
\hline Hodous T & $* 0114$ \\
\hline Hoffman C & $* 0109 * 0414$ \\
\hline Holcomb L & $* 0100$ \\
\hline Holden T & $* 0234$ \\
\hline
\end{tabular}




\begin{tabular}{|c|c|}
\hline Author & Citation Number(s) \\
\hline Holmes H & $* 0236$ \\
\hline Homce G & $* 0415$ \\
\hline Hoover M & $* 0416 * 0417$ \\
\hline Hoppin J & $* 0208$ \\
\hline Hornsby-Myers J & $* 0133 * 0433 * 0472$ \\
\hline Hornung R & $* 0230 * 0253$ \\
\hline Hota S & $* 0541 * 0542$ \\
\hline Hoving S & $* 0233$ \\
\hline Howard S & $* 0079 * 0080$ \\
\hline Howie W & $* 0286$ \\
\hline Hsiao H & $* 0050 * 0115 * 0116 * 0522 * 0571 * 0573$ \\
\hline Hsu V & $* 0417 \mathrm{a}$ \\
\hline Hu H & $* 0066 * 0099$ \\
\hline Hu S & $* 0418$ \\
\hline Huang B & $* 0162$ \\
\hline Huang $\mathrm{C}$ & $* 0059 * 0118 * 0162 * 0166 * 0295 * 0320 * 0321 * 0322 * 0373 * 0550$ \\
\hline Huang G & $* 0119$ \\
\hline Hubbs A & $\begin{array}{l}* 0028 * 0097 * 0120 * 0140 * 0214 * 0215 * 0278 * 0292 * 0352 * 0353 * 0419 * 0420 \\
* 0448 * 0461 * 0548 \mathrm{~b}\end{array}$ \\
\hline Hudnall J & $* 0365$ \\
\hline Hudock S & $* 0299 * 0309$ \\
\hline Huffman D & $* 0434 * 0435$ \\
\hline Huffman L & $* 0121$ \\
\hline Hulderman T & $* 0255 * 0298$ \\
\hline Hurrell J & $* 0297$ \\
\hline Huy J & $* 0122$ \\
\hline Iannacchione A & $* 0421 * 0422$ \\
\hline Ingram D & $* 0333$ \\
\hline Inman $\mathbf{C}$ & $* 0423$ \\
\hline Irwin $\mathrm{K}$ & $* 0338$ \\
\hline Iverson S & $* 0424 * 0511$ \\
\hline Jackson L & $* 0425 * 0702$ \\
\hline Jacob L & $* 0123$ \\
\hline Jacobs R & $* 0044$ \\
\hline Jantzen P & $* 0100$ \\
\hline Jappinen P & $* 0025 * 0154$ \\
\hline Jarabek A & $* 0317$ \\
\hline Jefferson A & $* 0237 * 0381 * 0515$ \\
\hline Jensen N & $* 0298 * 0456$ \\
\hline Jensen P & $\begin{array}{l}* 0045 * 0124 * 0186 * 0276 * 0350 * 0365 * 0366 * 0428 * 0453 * 0469 * 0470 * 0572 \\
* 0573\end{array}$ \\
\hline Jeran P & $* 0404$ \\
\hline Jernigan D & $* 0428 \mathrm{a}$ \\
\hline Jernigan J & $* 0559 \mathrm{a}$ \\
\hline Jernigan M & $* 0004$ \\
\hline Jiang B & $* 0090 * 0091 * 0118$ \\
\hline Johnson A & $* 0194 * 0218 * 0219$ \\
\hline Johnson E & $* 0126 * 0127$ \\
\hline
\end{tabular}




\begin{tabular}{|c|c|}
\hline Author & Citation Number(s) \\
\hline Johnson J & $* 0511 * 0537 * 0576$ \\
\hline Johnston O & $* 0309$ \\
\hline Johnston R & $* 0384 * 0561$ \\
\hline Jones A & $* 0071$ \\
\hline Jones E & $* 0071$ \\
\hline Jones R & $* 0277$ \\
\hline Jones W & $* 0120 * 0214 * 0346 * 0366 * 0419 * 0420 * 0446 * 0448 * 0470 * 0499$ \\
\hline Jorgensen M & $* 0429$ \\
\hline Joseph P & $* 0128 * 0129 * 0155 * 0430 * 0431$ \\
\hline Juarez A & $* 0066$ \\
\hline Kaczmarek R & $*^{*} 0056 * 0211$ \\
\hline Kadiiska M & $* 0250$ \\
\hline Kadlubar F & $* 0351$ \\
\hline Kagan B & ${ }^{*} 0251$ \\
\hline Kagan V & $* 0130 * 0191 * 0285 * 0543$ \\
\hline Kain B & $* 0431 \mathrm{a}$ \\
\hline Kane E & $* 0461 * 0506$ \\
\hline Kanwal R & $* 0328$ \\
\hline Karabin GJ J & $* 0467$ \\
\hline Karol M & $* 0176$ \\
\hline Kashon K & $* 0459$ \\
\hline Kashon M & $* 0097 * 0246 * 0261 * 0305 * 0314 * 0381 * 0515 * 0703$ \\
\hline Katz T & $* 0380 * 0517$ \\
\hline Kauppinen T & $* 0025 * 0154$ \\
\hline Kawai K & $* 0130 * 0251$ \\
\hline Ke Q & $* 0118$ \\
\hline Keane M & $* 0093 * 0133 * 0292 * 0392 \mathrm{a} * 0432 * 0433 * 0459 * 0477 * 0548 \mathrm{a} * 0548 \mathrm{~b} * 0703$ \\
\hline Kelley K & $* 0281$ \\
\hline Kellum M & $* 0236$ \\
\hline Kelly K & $* 0229$ \\
\hline Kennedy E & $* 0103$ \\
\hline Kenner B & $* 0533$ \\
\hline Kent M & $* 0098 * 0472 * 0518$ \\
\hline Keshava C & $* 0134 * 0302$ \\
\hline Keshava N & $* 0434 * 0435 * 0436$ \\
\hline Kesner J & $* 0225 * 0226 * 0303 * 0443$ \\
\hline Keswani J & $* 0361 * 0437$ \\
\hline Key-Schwartz R & $* 0274 * 0438$ \\
\hline Khabbaz R & $* 0372 \mathrm{a} * 0417 \mathrm{a}$ \\
\hline Khan A & $* 0053 * 0215 * 0216 * 0352 * 0417 \mathrm{a}$ \\
\hline Khan J & $* 0082 * 0083$ \\
\hline Khanina A & $* 0010$ \\
\hline Kiefer M & $* 0135$ \\
\hline Kielkowski D & $* 0025 * 0154$ \\
\hline Killefer J & $* 0140$ \\
\hline Kimmel C & $* 0282$ \\
\hline Kinneer K & $* 0171 * 0439 * 0463$ \\
\hline Kinnes G & $* 0236$ \\
\hline
\end{tabular}




\begin{tabular}{|c|c|}
\hline Author & Citation Number(s) \\
\hline Kirschke D & $* 0559 \mathrm{a}$ \\
\hline Kishi R & $* 0025 * 0154$ \\
\hline Kisin E & $* 0127 * 0130 * 0248 * 0249 * 0250$ \\
\hline Kissell F & $* 0136 * 0137 * 0440 * 0441$ \\
\hline Kittusamy N & $* 0138 * 0442$ \\
\hline Klandorf $\mathrm{H}$ & $* 0431 \mathrm{a}$ \\
\hline Klingner T & $* 0021 * 0139 * 0546$ \\
\hline Klusaritz B & $* 0236$ \\
\hline Klusaritz V & $* 0259$ \\
\hline Knecht E & $* 0225 * 0226 * 0303 * 0443 * 0524$ \\
\hline Knudsen G & $* 0444$ \\
\hline Kocamis H & $* 0140$ \\
\hline Koch S & $* 0229$ \\
\hline Kodell R & $* 0317$ \\
\hline Kohen M & $* 0428 \mathrm{a}$ \\
\hline Kohler J & $* 0141 * 0262 * 0441 * 0540$ \\
\hline Kommineni $\mathbf{C}$ & $* 0127 * 0248 * 0249 * 0250 * 0251 * 0456$ \\
\hline Koponen M & $* 0006 * 0175$ \\
\hline Korley F & $* 0095$ \\
\hline Koskela R & $* 0006 * 0174 * 0175$ \\
\hline Kosnett M & $* 0201$ \\
\hline Kovacs K & $* 0089$ \\
\hline Kovein R & $* 0069 * 0077 * 0078$ \\
\hline Kowalski K & $* 0142 * 0445 * 0503 * 0559$ \\
\hline Kozel P & $* 0143$ \\
\hline Krahenbuhl T & $* 0533$ \\
\hline Kreiss K & $\begin{array}{l}* 0144 * 0145 * 0156 * 0186 * 0199 * 0243 * 0302 * 0328 * 0370 * 0407 * 0419 * 0420 \\
* 0446 * 0447 * 0447 \mathrm{a} * 0448 * 0497 * 0516 * 0518\end{array}$ \\
\hline Krewski D & $* 0317$ \\
\hline Kriech A & $* 0168$ \\
\hline Krieg E & $* 0063$ \\
\hline Krieg EF J & $* 0053 * 0143 * 0194 * 0197 * 0225 * 0443 * 0524$ \\
\hline Kubale T & $* 0024$ \\
\hline Kuempel E & $* 0147 * 0148 * 0283$ \\
\hline Kullman G & $* 0120 * 0144 * 0145 * 0341 * 0346 * 0419 * 0420 * 0447 * 0448$ \\
\hline Kung H & $* 0040$ \\
\hline Kuppusamy $\mathbf{P}$ & $* 0159$ \\
\hline Kurimo R & $* 0077 * 0078 * 0098$ \\
\hline Kwan L & $* 0303$ \\
\hline Kyriazi N & $* 0449$ \\
\hline Lai D & $* 0253$ \\
\hline Lalich N & $* 0153$ \\
\hline Lande $\mathrm{K}$ & $* 0537$ \\
\hline Landsittel D & $* 0087 * 0149 * 0182 * 0212 * 0213 * 0214 * 0215 * 0216 * 0315$ \\
\hline Lange $\mathbf{R}$ & $* 0176$ \\
\hline Larson $M$ & $* 0567$ \\
\hline Larsson B & $* 0044 * 0229$ \\
\hline Larsson L & $* 0498$ \\
\hline Laserson K & $* 0372 \mathrm{a}$ \\
\hline
\end{tabular}




\begin{tabular}{|c|c|}
\hline Author & Citation Number(s) \\
\hline Launer $\mathbf{L}$ & $* 0209$ \\
\hline Law B & $* 0549$ \\
\hline Lawrence R & $* 0045 * 0341 * 0365 * 0366 * 0453 * 0470$ \\
\hline Lawryk N & $* 0150 * 0450 * 0451 * 0452$ \\
\hline Lawson C & $* 0151 * 0152$ \\
\hline Lazzara C & $* 0378$ \\
\hline Lee B & $* 0454$ \\
\hline Lee $\mathbf{E}$ & $* 0082 * 0083 * 0153$ \\
\hline Lee $M$ & $* 0221$ \\
\hline Lee W & *0154 \\
\hline Lei Y & $* 0128 * 0129 * 0155 * 0430 * 0431$ \\
\hline Leigh J & $* 0156$ \\
\hline LeMasters G & $* 0151 * 0225 * 0226 * 0351$ \\
\hline Lemus R & $* 0176$ \\
\hline Lentz T & $* 0157 * 0455$ \\
\hline Leonard S & $* 0040 * 0059 * 0090 * 0091 * 0118 * 0158 * 0159 * 0160 * 0212 * 0213 * 0362 * 0536$ \\
\hline Leonette J & $* 0444$ \\
\hline Lerch H & $* 0085$ \\
\hline Levin $\mathrm{H}$ & $* 0186$ \\
\hline Levin L & $* 0151$ \\
\hline Lewis A & $* 0536$ \\
\hline Lewis D & $\begin{array}{l}* 0002 * 0003 * 0044 * 0051 * 0108 * 0229 * 0238 * 0239 * 0301 * 0318 * 0319 * 0329 \\
* 0372 * 0549\end{array}$ \\
\hline Lewis $\mathbf{S}$ & $* 0282$ \\
\hline Lhamon M & $* 0511$ \\
\hline Li G & $* 0351$ \\
\hline Li H & $* 0161 * 0296$ \\
\hline Li J & $* 0059 * 0118 * 0162 * 0322 * 0331$ \\
\hline Liesivuori J & $* 0044$ \\
\hline Linch K & $* 0163 * 0485$ \\
\hline Lindblad A & $* 0194$ \\
\hline Lindsley W & $* 0358 * 0401 * 0456$ \\
\hline Line J & $* 0425 * 0702$ \\
\hline Lineberry G & $* 0457$ \\
\hline Linn $\mathbf{H}$ & $* 0273$ \\
\hline Listak J & $* 0368$ \\
\hline Little A & $* 0458$ \\
\hline Little M & $* 0195$ \\
\hline Litton C & $* 0164 * 0165$ \\
\hline Liu J & $* 0151$ \\
\hline Liu K & $* 0090$ \\
\hline Liu L & $* 0459 * 0703$ \\
\hline Liu $\mathbf{S}$ & $* 0543$ \\
\hline Liu Y & $*^{* 0014}$ \\
\hline Lockey J & $* 0225 * 0226$ \\
\hline Long D & $* 0116$ \\
\hline Lowe B & $* 0241$ \\
\hline Lowry D & $* 0237 * 0381 * 0515$ \\
\hline Lu B & $* 0166$ \\
\hline Lu Y & $* 0040 * 0362 * 0373$ \\
\hline
\end{tabular}




\begin{tabular}{|c|c|}
\hline Author & Citation Number(s) \\
\hline Lukacs S & $* 0417 \mathrm{a}$ \\
\hline Luna P & $* 0502$ \\
\hline Lund S & $* 0218 * 0219$ \\
\hline Lushniak B & $* 0051$ \\
\hline Luster M & $* 0176 * 0182 * 0246 * 0254 * 0255 * 0265 * 0298 * 0314 * 0315 * 0460 * 0493$ \\
\hline Lyons E & $* 0109$ \\
\hline Ma J & $\begin{array}{l}* 0002 * 0003 * 0004 * 0028 * 0097 * 0167 * 0168 * 0216 * 0292 * 0310 * 0312 * 0329 \\
* 0418 * 0461 * 0506 * 0548 \mathrm{~b} * 0565 * 0568\end{array}$ \\
\hline Ma Q & $* 0169 * 0170 * 0171 * 0411 * 0439 * 0462 * 0463$ \\
\hline MacDonald L & $* 0074$ \\
\hline MacKenzie B & $* 0017$ \\
\hline Magid D & $* 0109$ \\
\hline Maharaj S & $* 0085$ \\
\hline Mainelis G & $* 0172 * 0173$ \\
\hline Mainiero R & $* 0514$ \\
\hline Mal T & $* 0534$ \\
\hline Malit B & $* 0088$ \\
\hline Malkin R & *0252 \\
\hline Malkinson A & $* 0237$ \\
\hline Mallett L & $* 0445 * 0464$ \\
\hline Malmberg $\mathbf{P}$ & $* 0229$ \\
\hline Manley L & $* 0027$ \\
\hline Mannetje A & $* 0006 * 0174 * 0175 * 0270 * 0526$ \\
\hline Marcus M & $* 0152$ \\
\hline Mark C & $* 0359 * 0465 * 0466 * 0467 * 0468$ \\
\hline Marks E & $* 0256$ \\
\hline Marple V & $* 0502$ \\
\hline Marras W & $* 0052 * 0084 * 0089 * 0371 * 0391 * 0429$ \\
\hline Marsh S & $* 0019 * 0403$ \\
\hline Marshall J & $* 0393$ \\
\hline Martin G & $* 0417 \mathrm{a}$ \\
\hline Martin J & $* 0095 * 0096 * 0392 \mathrm{a} * 0433$ \\
\hline Martin S & $* 0366 * 0469 * 0470 * 0471 * 0472 * 0505$ \\
\hline Martinez A & $* 0010$ \\
\hline Masaki K & *0209 \\
\hline Mason R & $* 0250$ \\
\hline Mast E & $* 0559 \mathrm{a}$ \\
\hline Mast T & $* 0221$ \\
\hline Materna B & $* 0201$ \\
\hline Matheson J & $* 0176 * 0265$ \\
\hline Mathias P & $* 0288$ \\
\hline Matsura T & $* 0191$ \\
\hline Maxfield A & $* 0256$ \\
\hline Mayeux B & $* 0050$ \\
\hline Maynard A & $* 0177 * 0178 * 0179 * 0180 * 0181 * 0324 a$ \\
\hline Maynard R & $* 0179 * 0180$ \\
\hline Mazloum N & $* 0221$ \\
\hline Mazza S & $* 0292 * 0548 b$ \\
\hline McAllister S & $* 0236$ \\
\hline
\end{tabular}




\begin{tabular}{|c|c|}
\hline Author & Citation Number(s) \\
\hline McCammon J & $* 0068$ \\
\hline McCanlies E & $* 0134 * 0182 * 0302$ \\
\hline McCann M & $* 0457$ \\
\hline McCawley M & $* 0243 * 0417 * 0472 * 0518$ \\
\hline McCleery R & $* 0068$ \\
\hline McClellan J & $* 0559 \mathrm{a}$ \\
\hline McClellan R & $* 0282$ \\
\hline McDevitt J & $* 0183$ \\
\hline McDiarmid M & $* 0152$ \\
\hline McDowell T & $* 0375$ \\
\hline McGinn S & $* 0473$ \\
\hline McHugh E & $* 0474$ \\
\hline McKenzie EA J & $* 0475$ \\
\hline McKernan J & $* 0184$ \\
\hline McKewan W & $* 0343$ \\
\hline McKinney W & $* 0326 * 0388 * 0389 * 0476$ \\
\hline McKinstry M & $* 0298$ \\
\hline McLaurin J & $* 0215 * 0216 * 0352$ \\
\hline McMillian M & *0477 \\
\hline Mead K & $* 0185 * 0520$ \\
\hline Mead P & $* 0281$ \\
\hline Means K & $* 0079 * 0080$ \\
\hline Medan D & $* 0166 * 0295 * 0550$ \\
\hline Mehler L & $* 0349$ \\
\hline Meighan T & $* 0224$ \\
\hline Meirer F & $* 0519$ \\
\hline Meister R & $* 0201$ \\
\hline Melachrino J & $* 0100$ \\
\hline Melnick R & $* 0282 * 0519$ \\
\hline Mendell M & $* 0186 * 0187 * 0252$ \\
\hline Mercer R & $* 0120 * 0294 * 0295 * 0419 * 0420 * 0478 * 0479 * 0550 * 0551$ \\
\hline Merchenthaler I & $* 0305$ \\
\hline Metzler R & $* 0480 * 0481 * 0482 * 0483$ \\
\hline Meyer R & $* 0559 \mathrm{a}$ \\
\hline Michael K & $* 0484$ \\
\hline Michel O & $* 0044$ \\
\hline Mickelsen R & $* 0520$ \\
\hline Middendorf P & $* 0399 * 0485$ \\
\hline Millecchia L & $* 0028 * 0215 * 0352 * 0353 * 0550$ \\
\hline Miller A & $* 0188$ \\
\hline Miller D & $* 0126 * 0127 * 0189 * 0264 * 0265 * 0280 * 0486 * 0492$ \\
\hline Miller G & $* 0286$ \\
\hline Miller W & $* 0093 * 0190 * 0392 \mathrm{a} * 0459 * 0548 \mathrm{a} * 0703$ \\
\hline Milton D & $* 0186 * 0229$ \\
\hline Milton M & *0498 \\
\hline Mirer F & $* 0282$ \\
\hline Mirkes P & $* 0411$ \\
\hline Mishra M & $* 0298$ \\
\hline Modriansky M & $* 0191$ \\
\hline
\end{tabular}




\begin{tabular}{|c|c|}
\hline Author & Citation Number(s) \\
\hline Moffat $\mathrm{H}$ & $* 0124 * 0276$ \\
\hline Molinda G & $* 0468$ \\
\hline Monaghan W & $* 0538$ \\
\hline Morata T & $* 0123 * 0192 * 0193 * 0194 * 0195 * 0218 * 0219 * 0279$ \\
\hline Morgan D & $* 0100$ \\
\hline Morgan K & $* 0282$ \\
\hline Morteaga B & $* 0454$ \\
\hline Mortimer V & $* 0202$ \\
\hline Mosley A & $* 0549$ \\
\hline Mossman B & $* 0058$ \\
\hline Mowrey G & $* 0333 * 0538$ \\
\hline Mowrey K & $* 0159$ \\
\hline Moyer E & $* 0339 * 0340 * 0341 * 0428 * 0469 * 0471 * 0472 * 0487 * 0488$ \\
\hline Mucho T & $* 0397 * 0398 * 0422$ \\
\hline Mucino V & $* 0079 * 0080$ \\
\hline Mueller C & $* 0202 * 0284$ \\
\hline Muller P & $* 0259$ \\
\hline Mullinix L & $* 0299$ \\
\hline Murono E & $* 0152 * 0196$ \\
\hline Murphy D & $* 0017$ \\
\hline Murphy L & $* 0489 * 0490$ \\
\hline Murphy W & $* 0053 * 0197 * 0288$ \\
\hline Murray A & $* 0248 * 0249 * 0250$ \\
\hline Murray D & $* 0318$ \\
\hline Murray W & $* 0101$ \\
\hline Mutmansky J & $* 0502$ \\
\hline Myers J & $* 0106 * 0133 * 0433$ \\
\hline Myers W & $* 0045 * 0453$ \\
\hline Nath J & $* 0097$ \\
\hline Nelson J & $* 0548 \mathrm{a}$ \\
\hline Nelson $R$ & $* 0559 \mathrm{a}$ \\
\hline Neton $\mathbf{J}$ & $* 0198 * 0380 * 0517$ \\
\hline Newbraugh B & $* 0217$ \\
\hline Newton B & $* 0114$ \\
\hline Nguyen M & $* 0303$ \\
\hline Nimgade $A$ & $* 0284$ \\
\hline NIOSH & $\begin{array}{l}* 0491 * 0577 * 0578 * 0579 * 0580 * 0581 * 0582 * 0583 * 0584 * 0585 * 0586 * 0587 \\
* 0588 * 0589 * 0590 * 0591 * 0592 * 0593 * 0594 * 0595 * 0596 * 0597 * 0598 * 0599 \\
* 0600 * 0601 * 0602 * 0603 * 0604 * 0605 * 0606 * 0607 * 0608 * 0609 * 0610 \\
* 0610 \mathrm{*} * 0611 * 0612 * 0613 * 0614 * 0615 * 0616 * 0617 * 0618 * 0619 * 0620 \\
* 0621 * 0622 * 0622 \mathrm{a} * 0623 * 0624 * 0624 \mathrm{a} * 0625 * 0626 * 0626 \mathrm{*} * 0627 * 0627 \mathrm{a} \\
* 0628 * 0629 * 0630 * 0631 * 0632 * 0633 * 0634 * 0635 * 0636 * 0637 * 0638 * 0639 \\
* 0640 * 0641 * 0641 \mathrm{a} * 0642 * 0642 \mathrm{a} * 0644 * 0645 * 0646 * 0647 * 0648 * 0649 \\
* 0650 * 0651 * 0652 * 0653 * 0654 * 0655 * 0656 * 0657 * 0658 * 0659 * 0660 * 0661 \\
* 0662 * 0663 * 0664 * 0665 * 0666 * 0667 * 0668 * 0669 * 0670 * 0671 * 0672 * 0673 \\
* 0673 \mathrm{*} * 0674 * 0675 * 0676 * 0677 * 0678 * 0679 * 0680 * 0681 * 0682 * 0683 \\
* 0684 * 0685 * 0686 * 0687 * 0688 * 0689 * 0690 * 0691 * 0692 * 0693 * 0694 \\
* 0694 \mathrm{a} * 0695 * 0696 * 0697 * 0698 * 0699 * 0700 * 0701\end{array}$ \\
\hline Nylander-French L & $* 0208$ \\
\hline
\end{tabular}




\section{Author Index}

\begin{tabular}{|c|c|}
\hline Author & Citation Number(s) \\
\hline Nylen $\mathbf{P}$ & $* 0194$ \\
\hline O'Brien D & $* 0076$ \\
\hline O'Callaghan J & $* 0100 * 0126 * 0127 * 0189 * 0233 * 0264 * 0265 * 0364 * 0458 * 0486 * 0492 * 0493$ \\
\hline O'Connor P & $* 0274$ \\
\hline Odabasi A & $* 0327$ \\
\hline Odencrantz J & $* 0573$ \\
\hline Ogden T & $* 0011$ \\
\hline Olson B & $* 0502$ \\
\hline Ong T & $\begin{array}{l}* 0093 * 0128 * 0129 * 0155 * 0263 * 0361 * 0392 \mathrm{a} * 0430 * 0431 * 0433 * 0434 \\
* 0435 * 0436 * 0459 * 0477 * 0703\end{array}$ \\
\hline Opferman J & $* 0378$ \\
\hline Orem W & $* 0085$ \\
\hline Organiscak J & $* 0203 * 0355 * 0356 * 0357 * 0396$ \\
\hline Orr C & $* 0245$ \\
\hline Orr T & $* 0494$ \\
\hline Ortega H & $* 0199 * 0200$ \\
\hline Osipov A & $* 0130$ \\
\hline Ottlinger $\mathbf{M}$ & $* 0201$ \\
\hline Oyler D & $* 0466$ \\
\hline Pack D & $* 0159 * 0215$ \\
\hline Page E & $* 0202$ \\
\hline Page $S$ & $* 0203 * 0356$ \\
\hline Painter J & $* 0281$ \\
\hline Palermo T & $* 0204$ \\
\hline Pan C & $* 0363 * 0495$ \\
\hline Pappas D & $* 0496$ \\
\hline Parashar U & $* 0559 \mathrm{a}$ \\
\hline Park J & $* 0447 \mathrm{a} * 0497 * 0498 * 0516$ \\
\hline Park R & $* 0205 * 0206 * 0207$ \\
\hline Parks C & $* 0208$ \\
\hline Patton P & $* 0530$ \\
\hline Pawlas K & $* 0218 * 0219$ \\
\hline Pearce N & $* 0025 * 0154$ \\
\hline Pechter E & $* 0386$ \\
\hline Pendergrass S & $* 0448$ \\
\hline Perreault S & $* 0152$ \\
\hline Persson B & $* 0025 * 0154$ \\
\hline Petersen M & $* 0057 * 0069 * 0081 * 0187 * 0252$ \\
\hline Peterson J & $* 0311$ \\
\hline Petrie D & $* 0473$ \\
\hline Petrovitch H & $* 0209$ \\
\hline Petsko R & $* 0228$ \\
\hline Petsonk E & $* 0012 * 0056 * 0161 * 0210 * 0211 * 0296 * 0552$ \\
\hline Piacitelli C & $* 0346 * 0446 * 0448 * 0499$ \\
\hline Piacitelli G & $* 0066 * 0098 * 0184$ \\
\hline Piwnica-Worms H & $* 0362$ \\
\hline Podlesny A & $* 0142$ \\
\hline Poirier M & $* 0500$ \\
\hline
\end{tabular}




\begin{tabular}{|c|c|}
\hline Author & Citation Number(s) \\
\hline Popescu N & $* 0065$ \\
\hline Popovic T & $* 0236$ \\
\hline Popper J & $* 0209$ \\
\hline Porter D & $\begin{array}{l}* 0028 * 0120 * 0212 * 0213 * 0214 * 0215 * 0216 * 0313 * 0352 * 0353 * 0419 \\
* 0431 \mathrm{a}\end{array}$ \\
\hline Pothier L & $* 0108$ \\
\hline Powers J & $* 0217$ \\
\hline Prasher D & $* 0218 * 0219$ \\
\hline Prince $\mathbf{M}$ & $* 0220$ \\
\hline Prugh D & $* 0121$ \\
\hline Pustula J & $* 0221$ \\
\hline$\overline{\text { Qian Y }}$ & $* 0221 * 0501$ \\
\hline Qiao G & $* 0316$ \\
\hline Quinn C & $* 0372 \mathrm{a} * 0417 \mathrm{a}$ \\
\hline Radomsky M & $* 0503 * 0559$ \\
\hline Raghunathan P & $* 0428 \mathrm{a}$ \\
\hline Rakheja S & $* 0062 * 0222 * 0223 * 0306$ \\
\hline Ramani J & $* 0502$ \\
\hline Ramani R & $* 0503 * 0559$ \\
\hline Ramsey D & $* 0215 * 0216 * 0352 * 0438$ \\
\hline Rao C & $* 0370 * 0504 * 0505$ \\
\hline Rao K & $* 0224$ \\
\hline Reasor M & $* 0278 * 0384$ \\
\hline Reed L & $* 0105 * 0252$ \\
\hline Reh C & $* 0051 * 0274$ \\
\hline Rehak T & $* 0333$ \\
\hline Reilly M & $* 0386 * 0405 * 0406$ \\
\hline Reinke D & $* 0382$ \\
\hline Rengasamy A & $* 0461 * 0506$ \\
\hline Reponen T & $* 0172 * 0173$ \\
\hline Rethi L & $* 0503 * 0559$ \\
\hline Reutman S & $* 0225 * 0226$ \\
\hline Rexroat L & $* 0186$ \\
\hline Reynolds B & $* 0227$ \\
\hline Reynolds J & $* 0120 * 0228 * 0248 * 0388 * 0389 * 0527$ \\
\hline Reynolds S & $* 0049 * 0229 * 0237 * 0381 * 0515$ \\
\hline Rice C & $* 0023 * 0024$ \\
\hline Rice F & $* 0205 * 0507 * 0508 * 0509$ \\
\hline Richards J & $* 0227$ \\
\hline Rider J & $* 0368$ \\
\hline Ridzon R & $* 0559 \mathrm{a}$ \\
\hline Rinsky R & $* 0230 * 0253$ \\
\hline $\operatorname{Rix~B}$ & $* 0025 * 0154$ \\
\hline Roberts J & $* 0004 * 0091 * 0278 * 0312 * 0536 * 0565$ \\
\hline Robertson S & $* 0397 * 0398 * 0510$ \\
\hline Robey E & $* 0477$ \\
\hline Robinson J & $* 0231$ \\
\hline Robinson V & $* 0212 * 0213 * 0214 * 0215 * 0216 * 0313 * 0352 * 0566$ \\
\hline
\end{tabular}




\begin{tabular}{|c|c|}
\hline Author & Citation Number(s) \\
\hline Rodriguez H & $* 0511$ \\
\hline Rodriguez R & $* 0511$ \\
\hline Roegner K & $* 0184 * 0232$ \\
\hline Rojanasakul Y & $* 0040 * 0166 * 0294 * 0295 * 0550 * 0551$ \\
\hline Romano P & $* 0156$ \\
\hline Romero-Steiner S & $* 0372 \mathrm{a} * 0417 \mathrm{a}$ \\
\hline Ronaghi M & $* 0079 * 0080 * 0217$ \\
\hline Roscoe R & $* 0201$ \\
\hline Rosenberry K & $* 0388$ \\
\hline Rosenman K & $* 0405 * 0406$ \\
\hline Rosenman R & $* 0386$ \\
\hline Rosewell K & $* 0305$ \\
\hline Ross C & $* 0104$ \\
\hline Ross W & $* 0209$ \\
\hline Rothman N & $* 0351 * 0519$ \\
\hline Rowland JH I & $* 0514$ \\
\hline Rozovsky I & $* 0233$ \\
\hline Ruder A & $* 0069 * 0081 * 0187 * 0351$ \\
\hline Ruest M & $* 0016$ \\
\hline Ruff T & $* 0234$ \\
\hline Russell G & $* 0503 * 0559$ \\
\hline Rylander R & $* 0044$ \\
\hline Sacks H & $* 0137 * 0415 * 0482$ \\
\hline Sammarco J & $* 0512 * 0513$ \\
\hline Sammons D & $* 0017$ \\
\hline Sampson A & $* 0235$ \\
\hline Sanderson W & $* 0049 * 0208 * 0209 * 0236 * 0349$ \\
\hline Santos-Burgoa C & $* 0026$ \\
\hline Sapko M & $* 0514 * 0538$ \\
\hline Sargent L & $* 0237 * 0381 * 0515$ \\
\hline Sassone D & $* 0183$ \\
\hline Satterfield B & $* 0307 * 0564 \mathrm{a}$ \\
\hline Sauter $\mathbf{S}$ & $* 0119$ \\
\hline Savitz D & $* 0208$ \\
\hline Saxena Q & $* 0238$ \\
\hline Saxena R & $* 0238 * 0239$ \\
\hline Scabilloni J & $* 0294 * 0478 * 0479 * 0551$ \\
\hline Schaeffer V & $* 0282$ \\
\hline Schafer R & $* 0312 * 0565$ \\
\hline Scharf T & $* 0457 * 0503 * 0559$ \\
\hline Schenker M & $* 0156$ \\
\hline Schiffbauer W & $* 0240$ \\
\hline Schil D & $* 0406$ \\
\hline Schill D & $* 0199 * 0386 * 0405$ \\
\hline Schlecht P & $* 0005 * 0274$ \\
\hline Schleiff P & $* 0144 * 0292 * 0447 * 0447 \mathrm{a} * 0497 * 0516 * 0548 \mathrm{~b}$ \\
\hline Schnaas L & $* 0099$ \\
\hline Schnakenberg G & $* 0473$ \\
\hline
\end{tabular}




\begin{tabular}{|c|c|}
\hline Author & Citation Number(s) \\
\hline Schnorr T & $* 0152 * 0303$ \\
\hline Schopper A & $* 0062 * 0222 * 0223 * 0261 * 0306 * 0375 * 0562 * 0563$ \\
\hline Schor N & $* 0543$ \\
\hline Schrader S & $* 0152 * 0241$ \\
\hline Schubauer-Berigan M & $* 0242 * 0380 * 0517$ \\
\hline Schuchat A & $* 0417 \mathrm{a}$ \\
\hline Schuler C & $* 0243 * 0518$ \\
\hline Schulte P & $* 0244 * 0351 * 0519$ \\
\hline Schwartz J & $* 0099$ \\
\hline Schwegler-Berry D & $* 0120 * 0419 * 0420$ \\
\hline Schwerha D & $* 0245$ \\
\hline Scott A & $* 0246$ \\
\hline Seitz T & $* 0236$ \\
\hline Seixas N & $* 0161 * 0296$ \\
\hline Semenova V & $* 0372 \mathrm{a} * 0417 \mathrm{a}$ \\
\hline Senft J & $* 0237 * 0381 * 0515$ \\
\hline Serbinova E & $* 0130$ \\
\hline Serinkan B & $* 0130$ \\
\hline Sestito J & $* 0153$ \\
\hline Shane A & $* 0372 \mathrm{a}$ \\
\hline Sharp D & $* 0182 * 0209 * 0523$ \\
\hline Shelby M & $* 0152$ \\
\hline Shi X & $\begin{array}{l}* 0040 * 0041 * 0042 * 0043 * 0058 * 0059 * 0060 * 0090 * 0091 * 0118 * 0158 * 0159 \\
* 0160 * 0162 * 0166 * 0221 * 0295 * 0320 * 0321 * 0322 * 0362 * 0402 * 0501 * 0536 \\
* 0550\end{array}$ \\
\hline Shrader S & $* 0101$ \\
\hline Shubilla J & $* 0449$ \\
\hline Shughrue P & $* 0305$ \\
\hline Shukla R & $* 0225 * 0226$ \\
\hline Shull G & $* 0143$ \\
\hline Shulman S & $* 0076 * 0077 * 0078 * 0098 * 0247 * 0309 * 0520$ \\
\hline Shvedova A & $* 0127 * 0130 * 0191 * 0248 * 0249 * 0250 * 0251 * 0285 * 0543$ \\
\hline Sieber W & $* 0054 * 0070 * 0071 * 0188 * 0232 * 0252 * 0521$ \\
\hline Siegel L & $* 0372 \mathrm{a}$ \\
\hline Siegel P & $* 0002 * 0003 * 0168 * 0312 * 0318 * 0319 * 0329 * 0372 * 0549$ \\
\hline Siegfried K & *0299 \\
\hline Silbergeld E & $* 0282$ \\
\hline Silver S & $* 0230 * 0253$ \\
\hline Simeonov P & $* 0522$ \\
\hline Simeonova $\mathbf{P}$ & $* 0254 * 0255 * 0298 * 0314 * 0315$ \\
\hline Simoes E & $* 0144 * 0145 * 0447$ \\
\hline Simon S & $* 0101$ \\
\hline Simpson J & $* 0238 * 0239 * 0549$ \\
\hline Sinclair R & $* 0256$ \\
\hline Singh H & $* 0149 * 0235 * 0257 * 0523$ \\
\hline Sinkule E & $* 0258 * 0541 * 0542$ \\
\hline Slavin $\mathbf{T}$ & $* 0075$ \\
\hline Sleijffers A & $* 0314$ \\
\hline Sliwinska-Kowalska M & $* 0218 * 0219$ \\
\hline Small D & $* 0236 * 0259$ \\
\hline
\end{tabular}




\begin{tabular}{|c|c|}
\hline Author & Citation Number(s) \\
\hline Smith A & $* 0397 * 0398$ \\
\hline Smith C & $* 0249 * 0543$ \\
\hline Smith J & $* 0017 * 0101 * 0247 * 0260$ \\
\hline Smith R & $* 0147 * 0205 * 0337$ \\
\hline Smith T & $* 0066$ \\
\hline Smutz W & $* 0062 * 0261 * 0375 * 0562 * 0563 * 0564$ \\
\hline Snawder J & $* 0053 * 0524$ \\
\hline Snyder K & $* 0079 * 0080 * 0116 * 0217$ \\
\hline Soderholm S & $* 0094 * 0245$ \\
\hline Song B & $* 0263$ \\
\hline Song $\mathbf{R}$ & $* 0005 * 0011$ \\
\hline Sottile J & $* 0141 * 0262 * 0540$ \\
\hline Sparer J & $* 0014$ \\
\hline Spitz H & $* 0023 * 0024$ \\
\hline Spruill M & $* 0263$ \\
\hline Sriram K & $* 0264 * 0265 * 0493$ \\
\hline St. Clair E & $* 0208$ \\
\hline Starck J & $* 0218 * 0219$ \\
\hline Stayner L & $* 0147 * 0205 * 0207 * 0252 * 0266 * 0287 * 0525$ \\
\hline Steege A & $* 0073$ \\
\hline Steenland K & $* 0006 * 0174 * 0175 * 0268 * 0269 * 0270 * 0271 * 0272 * 0526$ \\
\hline Stemple K & $* 0228 * 0527$ \\
\hline Stephens J & $* 0133 * 0433$ \\
\hline Stephenson C & $* 0503 * 0529 * 0559$ \\
\hline Stephenson M & $* 0529 * 0560$ \\
\hline Stewart B & $* 0530$ \\
\hline Stewart J & $* 0046$ \\
\hline Stoica A & $* 0559 \mathrm{a}$ \\
\hline Stolarik B & $* 0388 * 0389$ \\
\hline Stone S & $* 0389 * 0461 * 0531 * 0549 * 0568$ \\
\hline Stout N & $* 0064 * 0273$ \\
\hline Streicher R & $* 0014 * 0015 * 0274$ \\
\hline Striley C & $* 0017 * 0053$ \\
\hline Succop P & $* 0023 * 0024$ \\
\hline Sulkowski W & $* 0218 * 0219$ \\
\hline Sullivan D & $* 0187$ \\
\hline Sullivan P & $* 0112 * 0413$ \\
\hline Summy J & $* 0221$ \\
\hline Sunyer J & $* 0154$ \\
\hline Sussell A & $* 0275$ \\
\hline Svensson E & $* 0194$ \\
\hline Swanson N & $* 0231$ \\
\hline Swanson P & $* 0532 * 0533$ \\
\hline Swerdlow D & $* 0281 * 0559 \mathrm{a}$ \\
\hline Syamlal G & $* 0485$ \\
\hline Szadkowska-Stanczyk I & $* 0025 * 0154$ \\
\hline Szponar B & $* 0498$ \\
\hline Talbot E & $* 0124 * 0276$ \\
\hline
\end{tabular}




\begin{tabular}{|c|c|}
\hline Author & Citation Number(s) \\
\hline Tanaka S & $* 0057$ \\
\hline Tanner C & $* 0209$ \\
\hline Tatu C & $* 0085$ \\
\hline Taylor C & $* 0534 * 0535$ \\
\hline Taylor L & $* 0236 * 0277$ \\
\hline Taylor M & $* 0278 * 0536$ \\
\hline Teass A & $* 0028 * 0063 * 0215 * 0216 * 0352$ \\
\hline Teixeira $\mathrm{C}$ & $* 0279$ \\
\hline Temple J & $* 0280$ \\
\hline Tennant $\mathbf{R}$ & $* 0519$ \\
\hline Tepper A & $* 0188$ \\
\hline Tesarik D & $* 0537 * 0576$ \\
\hline Teschke K & $* 0025 * 0154$ \\
\hline Teshale E & $* 0281$ \\
\hline Thimons E & $* 0356 * 0357 * 0369 * 0535$ \\
\hline Thomas D & $* 0317$ \\
\hline Thomas R & $* 0538$ \\
\hline Thompson D & $* 0256$ \\
\hline Thorgeirsson $\mathbf{S}$ & $* 0065$ \\
\hline Thorne P & $* 0044 * 0229$ \\
\hline Thun M & $* 0272$ \\
\hline Tierney B & $* 0372 \mathrm{a}$ \\
\hline Tierney J & $* 0110$ \\
\hline Tift B & $* 0527$ \\
\hline Timko R & $* 0061 * 0357 * 0535$ \\
\hline Tinkle S & $* 0246 * 0417$ \\
\hline Toledo D & $* 0166$ \\
\hline Tomblyn S & $* 0461 * 0568$ \\
\hline Toraason M & $* 0266 * 0282 * 0288 * 0519 * 0525$ \\
\hline Toren K & $* 0414$ \\
\hline Tran C & $* 0148 * 0283$ \\
\hline Treadwell E & $* 0208$ \\
\hline Trevits M & $* 0538 * 0539$ \\
\hline Trout D & $* 0284$ \\
\hline Trunov M & $* 0172$ \\
\hline Trutt F & $* 0141 * 0262 * 0540$ \\
\hline Tsaih S & *0099 \\
\hline Tseng C & $* 0230$ \\
\hline Tuchman D & $* 0061 * 0548$ \\
\hline Tumpowsky C & $* 0386 * 0405 * 0406$ \\
\hline Tupin E & $* 0236$ \\
\hline Turner N & $* 0258 * 0541 * 0542$ \\
\hline Turner $\mathbf{T}$ & $* 0101 * 0241$ \\
\hline Tyson F & $* 0237 * 0381 * 0515$ \\
\hline Tyurin $\mathrm{V}$ & $* 0191 * 0251 * 0285 * 0543$ \\
\hline Tyurina Y & $* 0191 * 0251 * 0285 * 0543$ \\
\hline Unger R & $* 0392$ \\
\hline Urosek J & $* 0539$ \\
\hline
\end{tabular}




\begin{tabular}{|c|c|}
\hline Author & Citation Number(s) \\
\hline$\overline{\text { Utt W }}$ & *0286 \\
\hline Utterback D & $* 0198$ \\
\hline Vainio H & $* 0287$ \\
\hline Valiante D & $* 0386 * 0405 * 0406$ \\
\hline Vallyathan V & $\begin{array}{l}* 0040 * 0058 * 0059 * 0063 * 0097 * 0158 * 0159 * 0160 * 0162 * 0182 * 0315 * 0479 \\
* 0544\end{array}$ \\
\hline van Loveren $\mathbf{H}$ & $* 0314$ \\
\hline Van Scott M & $* 0384 * 0385 * 0444 * 0561$ \\
\hline Van Campen L & $* 0288$ \\
\hline van Hattum J & $* 0314$ \\
\hline Vaught $\mathrm{C}$ & $* 0445 * 0464 * 0560$ \\
\hline Veililla A & $* 0407$ \\
\hline Vinson R & $* 0061 * 0548$ \\
\hline Viscusi D & $* 0572$ \\
\hline Vivekanandan B & *0364 \\
\hline Vo E & $* 0289 * 0545 * 0546$ \\
\hline Volberg O & $* 0547$ \\
\hline Volkwein J & $* 0440 * 0441 * 0502 * 0548$ \\
\hline Wagner G & $* 0012 * 0112 * 0335 * 0413 * 0552$ \\
\hline Walker T & $* 0236$ \\
\hline Walks I & $* 0372 \mathrm{a}$ \\
\hline Wallace M & $* 0290$ \\
\hline Wallace W & $\begin{array}{l}* 0093 * 0113 * 0133 * 0292 * 0392 \mathrm{a} * 0412 * 0432 * 0433 * 0459 * 0477 * 0548 \mathrm{a} \\
* 0548 \mathrm{~b} * 0703\end{array}$ \\
\hline Wallingford K & $* 0186 * 0252$ \\
\hline Wang J & $* 0549$ \\
\hline Wang L & $* 0166 * 0294 * 0295 * 0478 * 0479 * 0550 * 0551$ \\
\hline Wang M & $* 0012 * 0161 * 0296 * 0446 * 0485 * 0552$ \\
\hline Wang $\mathbf{S}$ & $* 0255$ \\
\hline Ward E & $* 0297 * 0519$ \\
\hline Warren C & $* 0375$ \\
\hline Warren $\mathbf{G}$ & $* 0298$ \\
\hline Washenitz F & $* 0114$ \\
\hline Wassell J & $* 0379 * 0553 * 0554$ \\
\hline Wasserman D & $* 0299$ \\
\hline Wasserman $\mathbf{J}$ & $* 0299$ \\
\hline Waters M & $* 0102 * 0351 * 0555$ \\
\hline Waters T & $* 0052 * 0075 * 0084 * 0088 * 0371 * 0429$ \\
\hline Watkins D & $* 0076 * 0077 * 0078$ \\
\hline Weatherly M & $* 0115$ \\
\hline Weber K & $* 0389$ \\
\hline Weiss E & $* 0496$ \\
\hline Weissman D & $* 0002 * 0003 * 0199 * 0200 * 0238 * 0239 * 0300 * 0301 * 0312 * 0329 * 0335 * 0527$ \\
\hline Welcome D & $* 0062 * 0222 * 0261 * 0375$ \\
\hline Wells C & $* 0124 * 0276$ \\
\hline Wenzl T & $* 0198$ \\
\hline Weston A & $* 0134 * 0302 * 0500 * 0519$ \\
\hline Whaley D & *0236 \\
\hline
\end{tabular}




\begin{tabular}{|c|c|}
\hline Author & Citation Number(s) \\
\hline Whelan E & $* 0102 * 0303$ \\
\hline White B & $* 0556 * 0557 * 0558$ \\
\hline White E & $* 0044$ \\
\hline White L & $* 0209$ \\
\hline Whitmer M & $* 0229$ \\
\hline Whong W & $* 0128 * 0129 * 0263 * 0431$ \\
\hline Whyatt J & $* 0557 * 0558$ \\
\hline Wiehagen W & $* 0457 * 0559$ \\
\hline Wigal T & *0471 \\
\hline Wilcock D & $* 0100$ \\
\hline Wilcox T & $* 0252$ \\
\hline Wilkins J & $* 0521$ \\
\hline Willard P & $* 0215 * 0352 * 0353$ \\
\hline Willeke K & $* 0172 * 0173$ \\
\hline Williams A & $* 0559 \mathrm{a}$ \\
\hline Williams L & $* 0521$ \\
\hline Williams T & $* 0557 * 0558$ \\
\hline Williamson A & $* 0064$ \\
\hline Wilson M & $* 0305$ \\
\hline Winthrop K & $* 0372 \mathrm{a}$ \\
\hline Wirth O & $* 0401$ \\
\hline Wise P & $* 0305$ \\
\hline Wiseman L & $* 0358$ \\
\hline Witte K & $* 0560$ \\
\hline Wolff M & $* 0134$ \\
\hline Wolinsky I & $* 0130$ \\
\hline Wood E & $* 0303$ \\
\hline Wood J & $* 0485$ \\
\hline Woodward C & $* 0286$ \\
\hline Woskie S & $* 0014 * 0015$ \\
\hline Wright S & $* 0281$ \\
\hline Wu D & $* 0385 * 0561$ \\
\hline $\mathbf{W u ~ J}$ & $* 0062 * 0223 * 0306 * 0375 * 0562 * 0563 * 0564$ \\
\hline Wu Z & $* 0307 * 0434 * 0435 * 0564 a$ \\
\hline Wurtz H & $* 0044$ \\
\hline Wurzelbacher S & $* 0299 * 0309$ \\
\hline Yadav J & $* 0172$ \\
\hline Yalowich J & $* 0191$ \\
\hline Yang H & $* 0004 * 0168$ \\
\hline Yang X & $* 0310$ \\
\hline Ye J & $* 0093 * 0216 * 0392 \mathrm{a} * 0439$ \\
\hline Yenchek M & $* 0311 * 0415$ \\
\hline Yereb D & $* 0417$ \\
\hline Yin S & $* 0351$ \\
\hline Yin $\mathrm{X}$ & $* 0312 * 0565 * 0568$ \\
\hline Yocum A & $* 0316$ \\
\hline Young S & $* 0313 * 0566$ \\
\hline Young F & $* 0014$ \\
\hline
\end{tabular}




\begin{tabular}{|c|c|}
\hline Author & Citation Number(s) \\
\hline Yuan B & $* 0065$ \\
\hline Yucesoy B & $* 0058 * 0182 * 0246 * 0314 * 0315$ \\
\hline Zabrocki R & $* 0281$ \\
\hline Zahl E & $* 0567$ \\
\hline Zang L & $* 0316$ \\
\hline Zeidler P & $* 0313$ \\
\hline Zeise L & $* 0317$ \\
\hline Zelanko J & $* 0467$ \\
\hline Zhang X & $* 0318 * 0319$ \\
\hline Zhang Z & $* 0090 * 0091 * 0320 * 0321 * 0322 * 0362 * 0402 * 0501 * 0551$ \\
\hline Zhao H & $* 0568$ \\
\hline Zheng B & $* 0085$ \\
\hline Zheng J & $* 0090 * 0091$ \\
\hline Zhong B & $* 0168$ \\
\hline Zhong X & $* 0118$ \\
\hline Zhou G & $* 0361$ \\
\hline Zhuang Z & $* 0045 * 0350 * 0365 * 0482 * 0483 * 0546 * 0569 * 0570 * 0571 * 0572 * 0573$ \\
\hline Zimmer A & $* 0181 * 0323 * 0324 * 0324 a$ \\
\hline Zimmer J & $* 0355 * 0535$ \\
\hline Zipf RK J & $* 0537 * 0574 * 0575 * 0576$ \\
\hline Zlochower I & $* 0514$ \\
\hline Zot $\mathbf{H}$ & $* 0221$ \\
\hline Zumwalde R & $* 0201$ \\
\hline
\end{tabular}




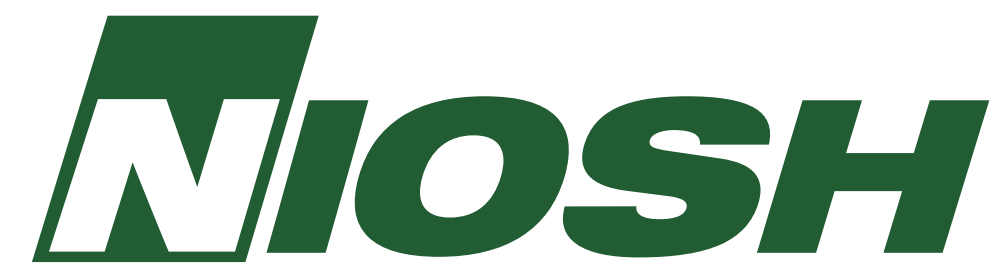

\section{Delivering on the Nation's Promise: \\ Safety and health at work for all people Through research and prevention}

For information about occupational safety and health topics contact NIOSH at:

1-800-35-NIOSH (1-800-356-4674)

Fax: 513-533-8573

E-mail: pubstaft@cdc.gov

www.cdc.gov/niosh

\section{SAFER・HEALTHIER・PEOPLE}

DHHS (NIOSH) Publication No. 2003-125 